\title{
QUANTITATIVE ASSESSMENT OF DISTRIBUTED ENERGY RESOURCE BENEFITS
}

May 2003

Prepared by S. W. Hadley J. W. Van Dyke W. P. Poore, III

T. K. Stovall 


\title{
DOCUMENT AVAILABILITY
}

Reports produced after January 1, 1996, are generally available free via the U.S. Department of Energy (DOE) Information Bridge:

Web site: http://www.osti.gov/bridge

Reports produced before January 1, 1996, may be purchased by members of the public from the following source:

\author{
National Technical Information Service \\ 5285 Port Royal Road \\ Springfield, VA 22161 \\ Telephone: 703-605-6000 (1-800-553-6847) \\ TDD: 703-487-4639 \\ Fax: 703-605-6900 \\ E-mail: info@ntis.fedworld.gov \\ Web site: http://www.ntis.gov/support/ordernowabout.htm
}

Reports are available to DOE employees, DOE contractors, Energy Technology Data Exchange (ETDE) representatives, and International Nuclear Information System (INIS) representatives from the following source:

Office of Scientific and Technical Information

P.O. Box 62

Oak Ridge, TN 37831

Telephone: 865-576-8401

Fax: 865-576-5728

E-mail: reports@adonis.osti.gov

Web site: http://www.osti.gov/contact.html

This report was prepared as an account of work sponsored by an agency of the United States Government. Neither the United States government nor any agency thereof, nor any of their employees, makes any warranty, express or implied, or assumes any legal liability or responsibility for the accuracy, completeness, or usefulness of any information, apparatus, product, or process disclosed, or represents that its use would not infringe privately owned rights. Reference herein to any specific commercial product, process, or service by trade name, trademark, manufacturer, or otherwise, does not necessarily constitute or imply its endorsement, recommendation, or favoring by the United States Government or any agency thereof. The views and opinions of authors expressed herein do not necessarily state or reflect those of the United States Government or any agency thereof. 


\title{
QUANTITATIVE ASSESSMENT OF DISTRIBUTED ENERGY RESOURCE BENEFITS
}

\author{
S. W. Hadley \\ J. W. Van Dyke \\ W. P. Poore, III \\ T. K. Stovall
}

May 2003

\author{
Sponsored by \\ Department of Energy \\ Office of Energy Efficiency and Renewable Energy \\ OAK RIDGE NATIONAL LABORATORY \\ Oak Ridge, Tennessee 37831 \\ managed by \\ UT-BATTELLE, LLC \\ for the \\ U.S. DEPARTMENT OF ENERGY \\ under contract No. DE-AC05-00OR22725
}





\section{CONTENTS}

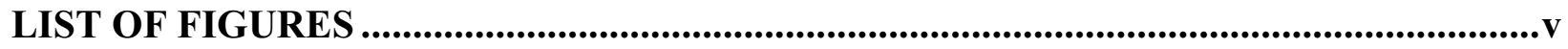

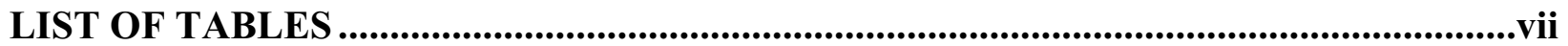

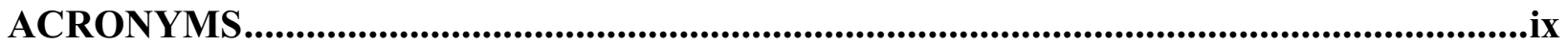

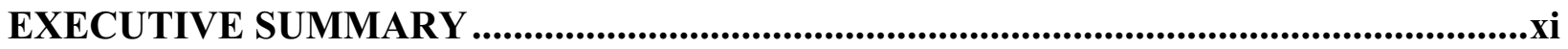

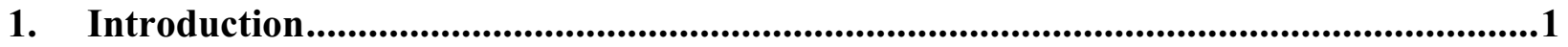

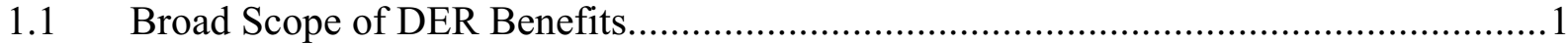

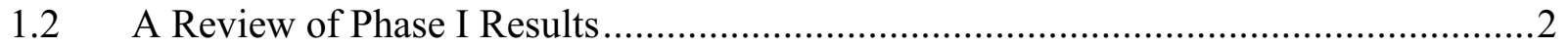

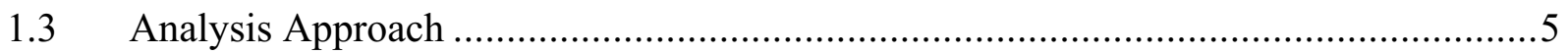

2. A Regional Analysis of Electricity Supply and Demand.....................................................

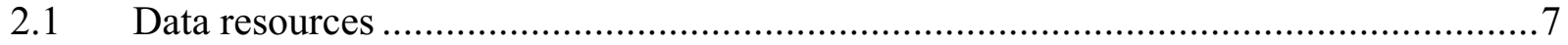

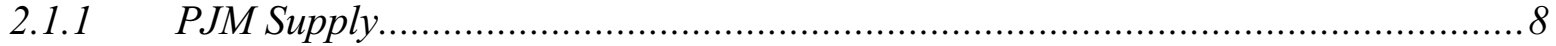

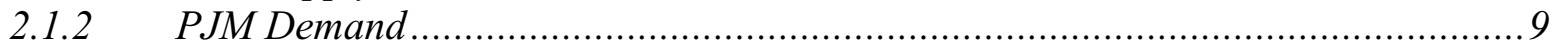

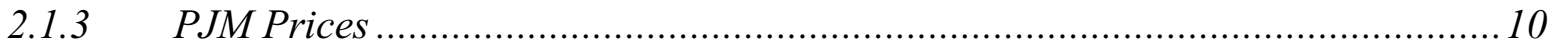

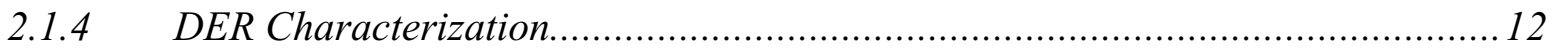

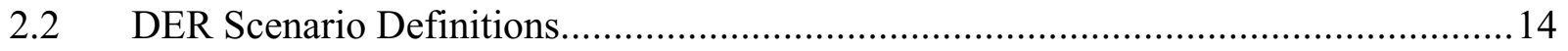

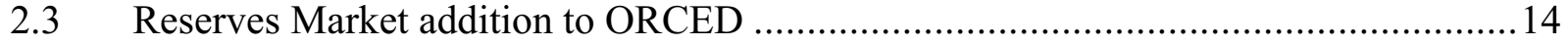

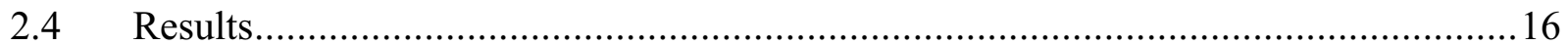

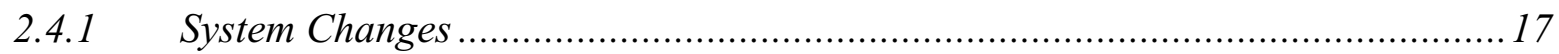

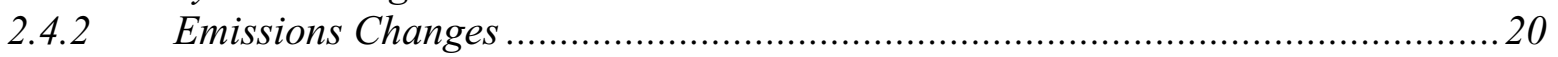

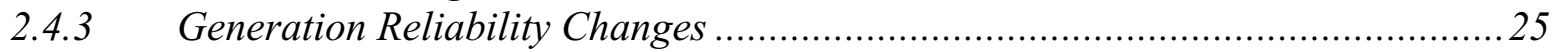

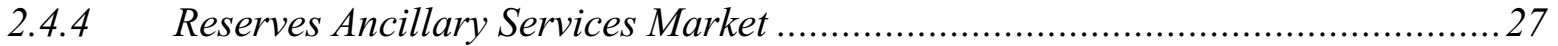

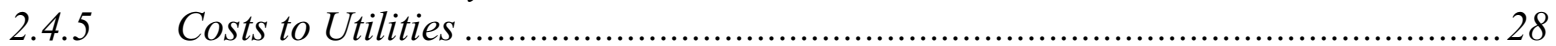

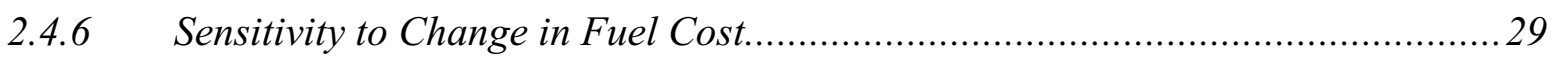

3. Long-Term Aggregate Avoided T\&D Costs.....................................................................31

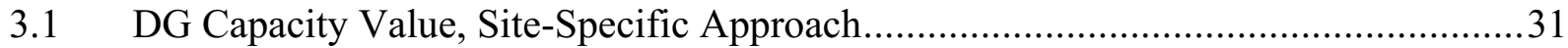

3.2 DG Capacity Value, Integrated System Approach......................................................... 31

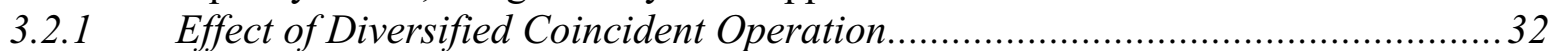

3.2.2 Effect on Upstream Distribution Capacity Requirements.................................. 33

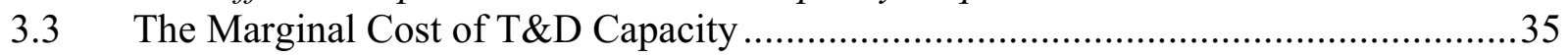

3.4 The Value of T\&D Investments Avoided by DG .......................................................36

4. DG Owner Economics in the PJM Region .........................................................................39

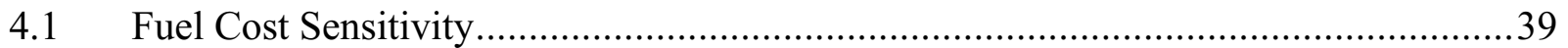

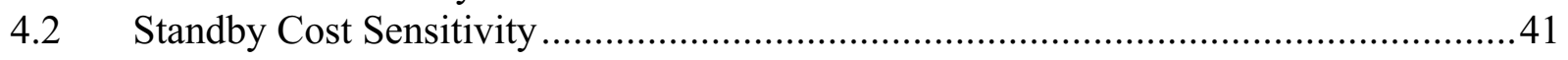

4.3 Results for a CHP Case in the PJM Region........................................................... 41

5. Conclusions................................................................................................................45

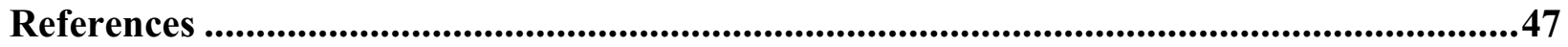

Appendix A - ORCED Methodology ......................................................................................

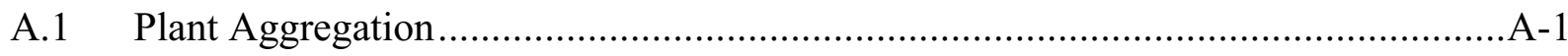

DER Benefits $\quad$ iii 


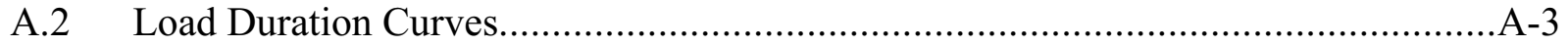

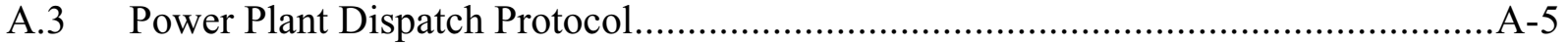

A.4 Dispatch Profile Response to DG................................................................... A-7

A.5 Operations, Emissions, and Prices on Hourly Basis............................................ A-7 


\section{LIST OF FIGURES}

Figure ES-1. Displaced energy by Peak and Baseload DG......................................................ii

Figure ES-2. Emissions reductions with Baseload DER ................................................. xiii

Figure ES-3. Ancillary services and emissions credits can affect payback - Peaking operation and PSE\&G rates (payback periods greater than 15 years not shown) ........................................

Figure 1. DER survey results: motivation for installation of current DER systems according to

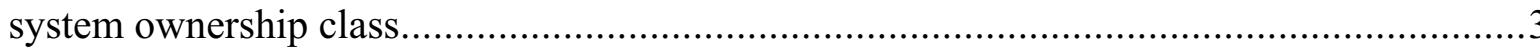

Figure 2. PJM region including all or parts of Pennsylvania, New Jersey, Maryland, and

Delaware. 7

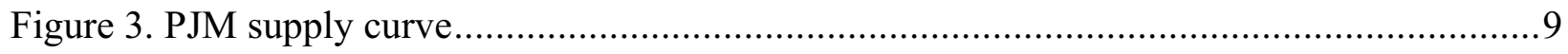

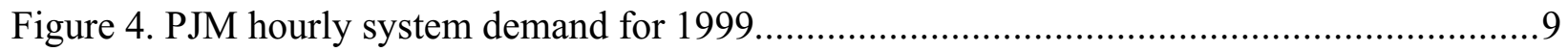

Figure 5. PJM average citygate gas price and hourly wholesale electric price.............................11

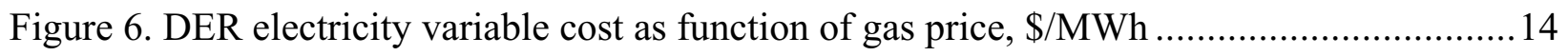

Figure 7. Example electricity demand of $3300 \mathrm{MW}$ and 7\% reserves requirement......................15

Figure 8. Displaced energy by Peak and Baseload DG ........................................................ 18

Figure 9. Energy prices, reserves prices, and power level for each season ................................19

Figure 10. PJM 1999 electricity wholesale prices and corresponding prices from ORCED........19

Figure 11. $\mathrm{Net}^{\mathrm{CO}_{2}}$ and $\mathrm{NO}_{\mathrm{x}}$ emissions from $100 \mathrm{MW}$ of Combustion Turbine-6B w/o CHP ....20

Figure 12. Net $\mathrm{CO}_{2}$ and $\mathrm{NO}_{\mathrm{x}}$ emissions from $100 \mathrm{MW}$ of Combustion Turbine-6B with CHP...23

Figure 13. System $\mathrm{NO}_{\mathrm{X}}$ savings as a function of the $\mathrm{DG} \mathrm{NO}_{\mathrm{X}}$ emissions rate ………................24

Figure 14. DG unit credit based on outage rates and 99.99\% reliability criteria ..........................35

Figure 15. Diagram of distribution capacity upstream from DG ……..................................... 37

Figure 16. Annual cost components for $200 \mathrm{~kW}$ DG with $80 \%$ capacity factor at projected Annual Energy Outlook prices for commercial natural gas …………................................39

Figure 17. DG electricity cost as function of gas price for microturbine ……............................40

Figure A-1. Operating cost and capacity of aggregated power plants in PJM region ................A-3

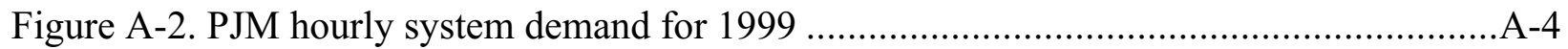

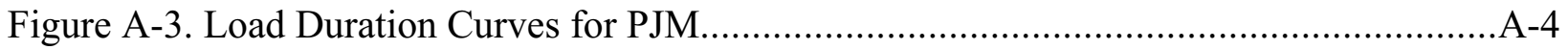

Figure A-4. Peak season dispatch of plants to meet PJM load in order of increasing variable cost. 



\section{LIST OF TABLES}

Table ES-1. Matrix of quantified benefits from DER and stakeholders (does not include benefits not studied)

Table ES-2. Key parameters of system power that is displaced by 100 MW of DER in the PJM region.

Table ES-3. Net emissions reductions for different DG technologies without CHP..... xiii

Table 1. Matrix of quantified benefits from DER and stakeholders (does not include benefits not analyzed).

Table 2. DER survey results: motivation for installation of current DER systems according to

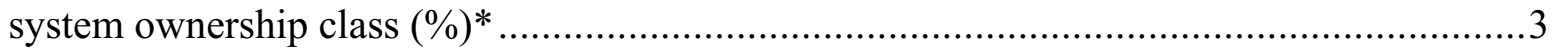

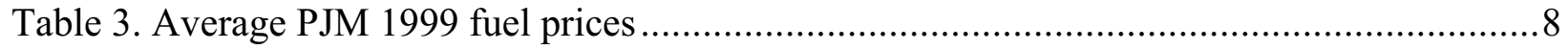

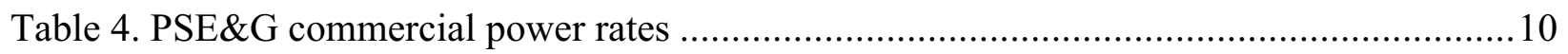

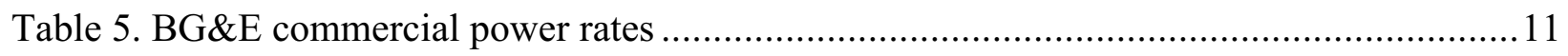

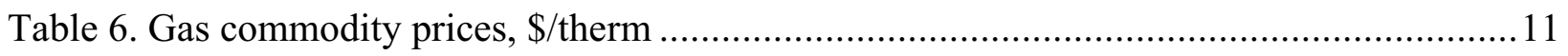

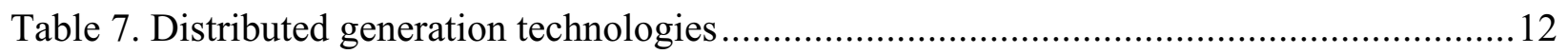

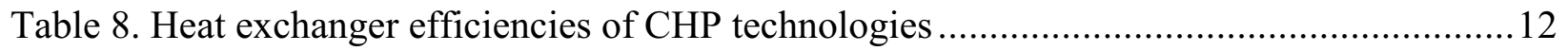

Table 9. Assumed reserves market parameters by technology.................................................... 16

Table 10. Production statistics from ORCED base case with no DER ........................................ 17

Table 11. Emissions statistics from ORCED base case with no DER .......................................... 17

Table 12. Displaced system power parameters ……......................................................... 18

Table 13. $\mathrm{CO}_{2}, \mathrm{NO}_{\mathrm{x}}$, and $\mathrm{SO}_{2}$ emissions reductions from $100 \mathrm{MW}$ of Combustion Turbine-6B

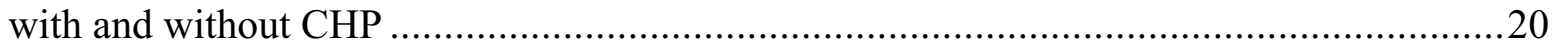

Table 14. Net emissions savings from $100 \mathrm{MW}$ of different DG technologies w/o CHP ............21

Table 15. Simple payback (years) for a non-CHP DG project with and without revenues from the sale of system emission credits for different technologies, using PSE\&G and BG\&E utility

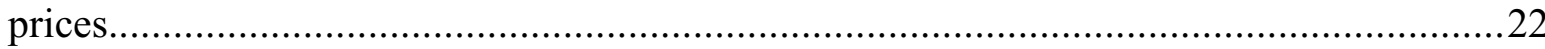

Table 16. Net emissions savings from $100 \mathrm{MW}$ of different DG technologies with CHP ...........23

Table 17. Simple payback (years) for a DER/CHP project with and without revenues from the sale of system emission credits for different technologies, using PSE\&G and BG\&E utility prices.

Table 18. Loss of Load Probability change when adding multiple smaller versus single larger plant

Table 19. Simple payback (years) for a Peaking-period-only DG project with and without revenues from the reserves ancillary market for different technologies, using different utility 
prices and a CHP option ..................................................................................... 28

Table 20. Utility net revenue changes with $100 \mathrm{MW}$ of DG ...............................................29

Table 21. Displaced system power parameters with 1999 and 2005 fuel prices......................29

Table 22 Maximum number of DG units available, based on 99.99\% reliability (or RC=.9999), for alternative DG outage rates and system diversity .......................................... 34

Table 23. End of year balance of distribution equipment for 105 nationwide utilities and 11 PJM utilities . 36

Table 24. Approach for calculating the value of transmission and distribution equipment costs avoided by distributed generation 38

Table 25. Commercial and industrial prices of natural gas in PJM service area for 1993 through 2001 41

Table 26. Net benefits for alternative DG technologies and fuel price scenarios ....................42

Table 27. Results from quantification of benefits. 46

Table A-1. PJM units aggregated by technology, fuel, and dispatchability..........................A-2

Table A-2. 1999 PJM electric sales with calculated factors to match system LDC A-5 


\section{ACRONYMS}

\begin{tabular}{|c|c|}
\hline $\mathrm{AEO}$ & Annual Energy Outlook \\
\hline BCHP & Building Cooling, Heating, and Power \\
\hline BG\&E & Baltimore Gas and Electric \\
\hline $\mathrm{CC}$ & Combined Cycle \\
\hline $\mathrm{CHP}$ & Combined Heat and Power \\
\hline $\mathrm{CT}$ & Combustion Turbine \\
\hline DER & Distributed Energy Resource \\
\hline DG & Distributed Generation \\
\hline EIA & Energy Information Administration \\
\hline EOYB & End of Year Balance \\
\hline EPA & Environmental Protection Agency \\
\hline FERC & Federal Energy Regulatory Commission \\
\hline GBtu & Billion British thermal units \\
\hline GWh & GigaWatt-hour $=1,000 \mathrm{MWh}$ \\
\hline $\mathrm{LDC}$ & Load Duration Curve \\
\hline LOLP & Loss of Load Probability \\
\hline MSW & Municipal Solid Waste \\
\hline MWh & MegaWatt-hour \\
\hline mmBtu & million British thermal units \\
\hline NEMS & National Energy Modeling System \\
\hline O\&M & Operations and Maintenance \\
\hline PJM & Pennsylvania, New Jersey, Maryland Interconnection LLC \\
\hline PPL & Pennsylvania Power and Light \\
\hline
\end{tabular}




$\begin{array}{ll}\text { PSE\&G } & \text { Public Service Electric \& Gas } \\ \text { PURPA } & \text { Public Utilities Regulatory Policy Act } \\ \text { RC } & \text { Reliability Criteria } \\ \text { ST } & \text { Steam Turbine } \\ \text { T\&D } & \text { Transmission and Distribution } \\ \text { TWh } & \text { TeraWatt-hour }=1,000 \mathrm{Gwh}\end{array}$




\section{EXECUTIVE SUMMARY}

Distributed energy resources (DER) offer many benefits, some of which are readily quantified. Other benefits, however, are less easily quantifiable because they may require site-specific information about the DER project or analysis of the electrical system to which the DER is connected. The purpose of this study is to provide analytical insight into several of the more difficult calculations, using the PJM power pool as an example. This power pool contains most of Pennsylvania, New Jersey, Maryland, and Delaware. The techniques used here could be applied elsewhere, and the insights from this work may encourage various stakeholders to more actively pursue DER markets or to reduce obstacles that prevent the full realization of its benefits.

This report describes methodologies used to quantify each of the benefits listed in Table ES-1. These methodologies include bulk power pool analyses, regional and national marginal cost evaluations, as well as a more traditional cost-benefit approach for DER owners. The methodologies cannot however determine which stakeholder will receive the benefits; that must be determined by regulators and legislators, and can vary from one location to another.

Table ES-1. Matrix of quantified benefits from DER and stakeholders (does not include benefits not studied)

\begin{tabular}{|c|c|c|c|}
\hline Benefit & Owner & Utility & Society \\
\hline Lower Cost & $\begin{array}{l}\text { Savings based on } \\
\text { electricity and thermal } \\
\text { savings versus cost of } \\
\text { DER }\end{array}$ & $\begin{array}{l}\text { Change based on } \\
\text { marginal cost reduction } \\
\text { versus reduced sales } \\
\text { revenue }\end{array}$ & $\begin{array}{l}\text { Savings based on } \\
\text { marginal cost reduction } \\
\text { and cost of DG }\end{array}$ \\
\hline Reliability & $\begin{array}{l}\text { Increased reliability } \\
\text { through added electricity } \\
\text { source, with backup from } \\
\text { grid }\end{array}$ & $\begin{array}{l}\text { Multiple small sources } \\
\text { lower needed reserve for } \\
\text { equivalent reliability }\end{array}$ & $\begin{array}{l}\text { Improved power } \\
\text { services, or reduced } \\
\text { economic cost of current } \\
\text { services }\end{array}$ \\
\hline Ancillary services & $\begin{array}{l}\text { Selling ancillary services } \\
\text { in market adds revenue }\end{array}$ & $\begin{array}{l}\text { DG may be lower cost } \\
\text { source of ancillary } \\
\text { services }\end{array}$ & \\
\hline Emissions reductions & $\begin{array}{l}\text { Owner may get credit for } \\
\text { net reductions in area } \\
\text { emissions }\end{array}$ & $\begin{array}{l}\text { Utility needs fewer } \\
\text { emissions permits to } \\
\text { meet caps }\end{array}$ & $\begin{array}{l}\text { Lower overall emissions } \\
\text { if DER is cleaner than } \\
\text { alternative }\end{array}$ \\
\hline $\begin{array}{l}\text { T\&D expansion } \\
\text { postponement }\end{array}$ & & $\begin{array}{l}\text { Savings based on } \\
\text { marginal cost of } \\
\text { expansion versus } \\
\text { embedded cost }\end{array}$ & $\begin{array}{l}\text { Delays disruptions and } \\
\text { cost of added T\&D } \\
\text { infrastructure }\end{array}$ \\
\hline
\end{tabular}

A bulk power system analysis was used to explore the effects of DER on the overall system, including the emissions, reliability, reserves ancillary services, and utility revenues. These analyses were expanded to cover the effect of fuel price changes as well. This system analysis used 1999 utility data, and looked at two possible application strategies for DER, first - where DER is only used during on-peak hours, and second - where DER is base-loaded. A summary of the net changes to the system for these two strategies is shown in Figure ES-1 and Table ES-2. The average marginal cost of the power displaced by the DER supply was $2.99 \notin / \mathrm{kWh}$ for the peaking strategy and $2.62 \phi / \mathrm{kWh}$ for baseload distributed generation (DG). This marginal cost will vary over the year, depending on which generating units are displaced. Most of each season 
the price stays below $3 \notin / \mathrm{kWh}$, but for the $10 \%$ of the time when the system demand is at its greatest, the price rises rapidly.

Figure ES-1. Displaced energy by Peak and Baseload DG

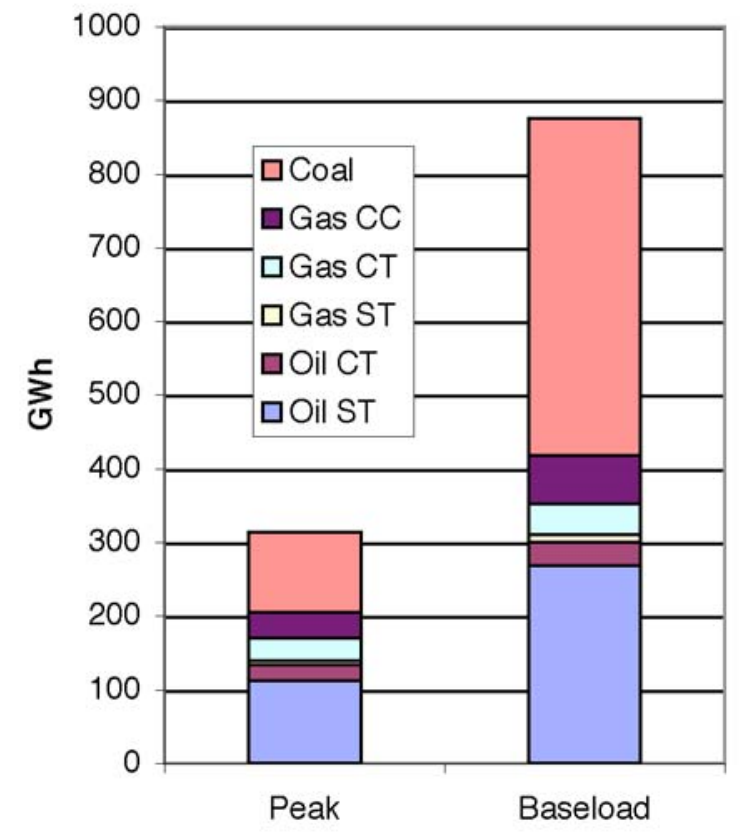

Table ES-2. Key parameters of system power that is displaced by $100 \mathrm{MW}$ of DER in the PJM region.

\begin{tabular}{|c|c|c|}
\hline & $\begin{array}{l}\text { Peaking } \\
\text { DG }\end{array}$ & $\begin{array}{c}\text { Baseload } \\
\text { DG }\end{array}$ \\
\hline $\begin{array}{l}\text { Displaced Energy, GWh } \\
\text { Displaced Source }\end{array}$ & 313 & 876 \\
\hline Oil ST & $36 \%$ & $31 \%$ \\
\hline Oil CT & $7 \%$ & $4 \%$ \\
\hline Gas ST & $2 \%$ & $1 \%$ \\
\hline Gas CT & $10 \%$ & $5 \%$ \\
\hline Gas CC & $11 \%$ & $8 \%$ \\
\hline Coal & $35 \%$ & $52 \%$ \\
\hline Avg Displaced Efficiency & $31 \%$ & $32 \%$ \\
\hline $\mathrm{NO}_{\mathrm{x}}, \mathrm{Ib} / \mathrm{MWh}$ & 3.03 & 3.59 \\
\hline $\mathrm{SO}_{2}, \mathrm{Ib} / \mathrm{MWh}$ & 9.67 & 13.1 \\
\hline $\mathrm{CO}_{2}, \mathrm{Ib} / \mathrm{MWh}$ & 1,938 & 1,972 \\
\hline Avg. Marginal Cost, $\phi / k W h$ & 2.99 & 2.62 \\
\hline $\begin{array}{l}\text { ST }=\text { steam turbine } \\
\mathrm{CT}=\text { combustion turbine } \\
\mathrm{CC}=\text { combined cycle }\end{array}$ & & \\
\hline
\end{tabular}

One of the principal societal benefits of DER is the potential for improved air quality. To the extent that cogeneration is used to improve the overall system energy efficiency, and to the extent that cleaner fuels are substituted for more-polluting fuels, DG will reduce the net regional emissions. Table ES-3 shows the net savings for each technology after subtracting the DER system emissions. Without Combined Heat and Power (CHP), the cleanest technology is the fuel cell, especially for $\mathrm{CO}_{2}$, because of its rated high efficiency, but other less expensive technologies are able to achieve over $90 \%$ of the fuel cell's NOx savings. Our analysis showed that baseload DER in the PJM region, especially as CHP, could reduce $\mathrm{NO}_{\mathrm{X}}$ emissions by as much as $7.3 \mathrm{lb} / \mathrm{MWh}, \mathrm{SO}_{2}$ by as much as $13 \mathrm{lb} / \mathrm{MWh}$, and $\mathrm{CO}_{2}$ by almost $1500 \mathrm{lb} / \mathrm{MWh}$ as shown in Figure ES-2. (Peaking DER would have slightly lower values.) Assuming market values for the $\mathrm{SO}_{2}$ and $\mathrm{NO}_{\mathrm{X}}$ of $\$ 200$ /ton and $\$ 1500$ /ton (with $\mathrm{NO}_{\mathrm{X}}$ charges only during the summer months) the savings can be as much as $0.31 \propto / \mathrm{kWh}$. Who reaps these benefits depends on the regulations involved in the calculation and sale of emission permits (as well as the location of the DER and the displaced central generators), but in the end, all of society reaps the benefit of cleaner air. 
Table ES-3. Net emissions reductions for different DG technologies without CHP

\begin{tabular}{|c|c|c|c|c|}
\hline \multirow[b]{2}{*}{ Technology } & \multicolumn{2}{|c|}{ Peaking DG } & \multicolumn{2}{|c|}{ Base Load DG } \\
\hline & $\begin{array}{c}\mathrm{CO}_{2} \\
\mathrm{lb} / \mathrm{MWh}\end{array}$ & $\begin{array}{c}\mathrm{NO}_{\mathrm{x}} \\
\mathrm{lb} / \mathrm{MWh}\end{array}$ & $\begin{array}{c}\mathrm{CO}_{2} \\
\mathrm{Ib} / \mathrm{MWh}\end{array}$ & $\begin{array}{c}\mathrm{NO}_{\mathrm{x}} \\
\mathrm{Ib} / \mathrm{MWh}\end{array}$ \\
\hline Fuel Cell-2 & 1002 & 3.02 & 1036 & 3.50 \\
\hline Microturbine-2B & 354 & 2.48 & 388 & 2.96 \\
\hline Combustion Turbine-2D & 476 & 1.64 & 510 & 2.12 \\
\hline Combustion Turbine-6D & 476 & 2.75 & 510 & 3.23 \\
\hline Combustion Turbine-6B & 548 & 2.76 & 582 & 3.24 \\
\hline Natural Gas Engine-2C & 772 & 0.66 & 806 & 1.13 \\
\hline Natural Gas Engine-6C & 772 & 2.78 & 806 & 3.25 \\
\hline
\end{tabular}

Figure ES-2. Emissions reductions with Baseload DER
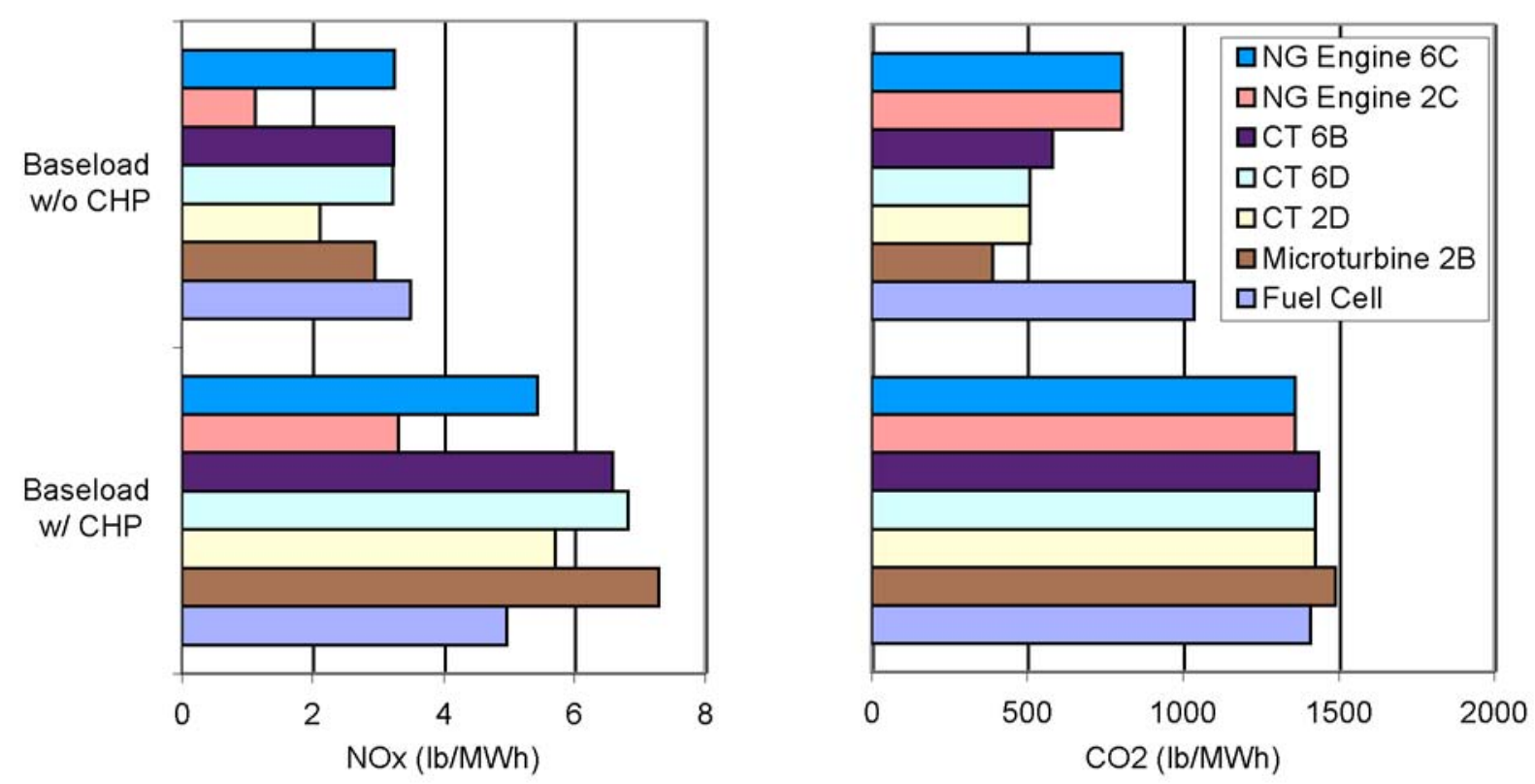

Based on the reliability analysis, there is a small but positive value to having capacity added at typical DG unit sizes as opposed to typical central station sizes. In addition, if DER owners are permitted to participate in the reserves ancillary market or the emissions trading market, the additional revenue can reduce the payback period by over $10 \%$. The overall project economics are improved to a much greater degree when the waste heat is employed in a combined heat and power (CHP) system, as shown in Figure ES-3. But the most important factors in any DER economic evaluation are the local electricity rates and fuel costs.

Utilities may or may not see a benefit from the application of DER. If the utility does not own the DER, the lost revenue from lower sales will likely be higher than the reduction in costs. Considering only displaced power production costs and revenue in our example, PSE\&G would have net annual losses of $\$ 140 / \mathrm{kW}$ for peaking DG and $\$ 370 / \mathrm{kW}$ for base-load DG. Because of its different rate structure, BG\&E would lose only $\$ 50 / \mathrm{kW}$ and $\$ 40 / \mathrm{kW}$ for the same two cases. The utilities may also have lower operating costs in other categories, but most of these other costs do not vary proportional to the amount of electricity sold. In the long run, the utilities will 
also save through deferral of transmission and distribution (T\&D) expenditures, as evaluated separately in this report using a marginal cost methodology.

Figure ES-3. Ancillary services and emissions credits can affect payback - Peaking operation and PSE\&G rates (payback periods greater than 15 years not shown)

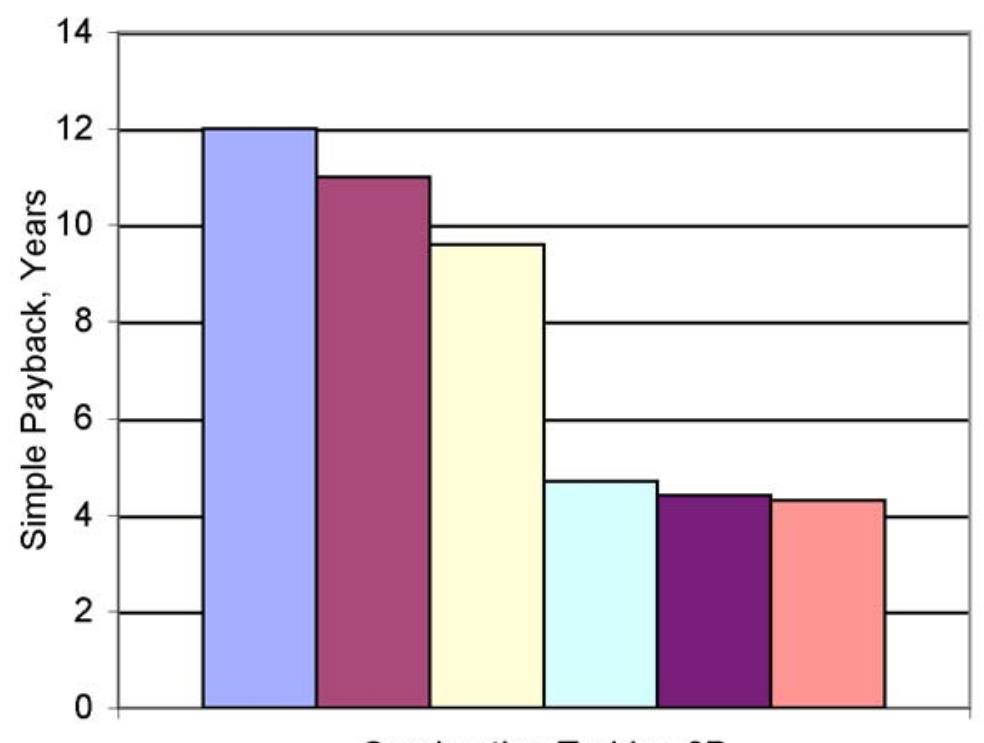

$\square$ w/o CHP no credits
$\square$ w/o CHP with emissions credit
$\square$ w/o CHP with reserves credit
$\square \mathrm{CHP}$ no credits
$\square \mathrm{CHP}$ with emissions credit
$\square \mathrm{CHP}$ with reserves credit

Combustion Turbine 6B

The type of power production displaced by DG can be sensitive to factors such as the price of fuels for the grid's power plants or other external factors. Changes in relative prices can alter the order of plants on the margin and change the marginal emissions and prices. For example, when the results for projected 2005 fuel prices are compared to the results for 1999 fuel prices, several interesting changes occur. In the Peaking scenario, the major change is the reduction in coal and increase in gas as the marginal production, while in the Baseload scenario oil decreases and gas increases as the marginal fuel. These factors therefore affect the emissions savings as well as the costs of the displaced power.

Avoided T\&D costs for DG do not necessarily occur at the same time that DG capacity is added because often the T\&D resources are already in place. However, in the long run, T\&D resources must be maintained, replaced, and usually augmented to meet system growth. Therefore, in the long-term view, DG should contribute to a reduction in T\&D expenses. The marginal-cost methodology employed here first estimates the diversified coincident effect of DG on the system, considering unit size, unit forced outage rate, and number of DG units. The diversified DG contribution is then combined with the marginal costs of T\&D assets to give an estimate of potentially avoided T\&D capacity costs. For the example case evaluated here, the PJM utilities would avoid T\&D costs of about $\$ 150 / \mathrm{kW}$ of installed DG capacity.

A traditional cost-benefit analysis was also completed to examine the economics for a DG owner in the PJM region. Fuel and electricity prices vary widely within this region. Standby charges especially differ from one utility to another. For some commercial and industrial customers served by PSE\&G, DG with CHP would have a reasonably short payback time. However, for customers served by PP\&L, the DG system would cost more to operate than the alternative of purchasing power from the utility, even considering the efficiency benefits of CHP. 


\section{Quantitative Assessment of Distributed Energy Resource Benefits}

\section{Introduction}

Distributed Energy Resources (DER) are systems that produce electrical power at the site where the power is needed. If only electrical power is used then the technology is called Distributed Generation (DG). If, in addition to the electrical power, the thermal exhaust from the generation process is used for other processes in the building (such as boilers or chillers) then it is called Combined Heat and Power (CHP), or cogeneration.

\subsection{Broad Scope of DER Benefits}

There are numerous benefits to using DER. These benefits may accrue to the owners, the utility, or the general populace. Many of these benefits are quantifiable, as reported in numerous studies (USDOE 2000, Bryson 2001, USCHPA 2001, Smith 2001, Cowart 2001, Goel 1998, Kirby 2001, Smith 2000). Some aspects, though, are more difficult to quantify, either because they require site-specific information about the DER project, or because they require analysis of the electrical system as a whole. The purpose of this paper is to provide analytical insight into several of these more difficult calculations, using the PJM power pool as an example. This power pool contains most of Pennsylvania, New Jersey, Maryland, and Delaware. It is advancing the state of the art in electricity markets and consequently evolving its rules and market definitions. The techniques used here could be applied by utilities within PJM and elsewhere, and the enhanced appreciation of DER benefits from this study may encourage various stakeholders to more actively pursue DER markets. It will not give a definitive answer as to whether a particular DER project in a given location has benefits outweighing costs; no broad study could, given the site-specific nature of DER. However, by analyzing the effect of DER/CHP on a large power pool, we can gain insight regarding system-wide changes.

Benefits from DER may be received by different stakeholders, as summarized in Table 1. The owners of the DER will receive benefits from owning and operating the equipment. The utility that would otherwise have provided the electricity may benefit depending on the comparative cost and revenue from servicing this load. Indirect participants in the project, such as local, regional, and national societies, may receive external benefits. 
Table 1. Matrix of quantified benefits from DER and stakeholders (does not include benefits not analyzed)

\begin{tabular}{|c|c|c|c|}
\hline Benefit & Owner & Utility & Society \\
\hline Lower Cost & $\begin{array}{l}\text { Savings based on } \\
\text { electricity and thermal } \\
\text { savings versus cost of } \\
\text { DER }\end{array}$ & $\begin{array}{l}\text { Change based on } \\
\text { marginal cost reduction } \\
\text { versus reduced sales } \\
\text { revenue }\end{array}$ & $\begin{array}{l}\text { Savings based on } \\
\text { marginal cost reduction } \\
\text { and cost of } D G\end{array}$ \\
\hline Reliability & $\begin{array}{l}\text { Increased reliability } \\
\text { through added electricity } \\
\text { source, with backup from } \\
\text { grid }\end{array}$ & $\begin{array}{l}\text { Multiple small sources } \\
\text { lower needed reserve for } \\
\text { equivalent reliability }\end{array}$ & $\begin{array}{l}\text { Improved power } \\
\text { services, or reduced } \\
\text { economic cost of current } \\
\text { services }\end{array}$ \\
\hline Ancillary services & $\begin{array}{l}\text { Selling ancillary services } \\
\text { in market adds revenue }\end{array}$ & $\begin{array}{l}\text { DG may be lower cost } \\
\text { source of ancillary } \\
\text { services }\end{array}$ & \\
\hline $\begin{array}{l}\text { Emissions } \\
\text { reductions }\end{array}$ & $\begin{array}{l}\text { Owner may get credit for } \\
\text { net reductions in area } \\
\text { emissions }\end{array}$ & $\begin{array}{l}\text { Utility needs fewer } \\
\text { emissions permits to meet } \\
\text { caps }\end{array}$ & $\begin{array}{l}\text { Lower overall emissions } \\
\text { if DER is cleaner than } \\
\text { alternative }\end{array}$ \\
\hline $\begin{array}{l}\text { T\&D expansion } \\
\text { postponement }\end{array}$ & & $\begin{array}{l}\text { Savings based on } \\
\text { marginal cost of } \\
\text { expansion versus } \\
\text { embedded cost }\end{array}$ & $\begin{array}{l}\text { Delays disruptions and } \\
\text { cost of added T\&D } \\
\text { infrastructure }\end{array}$ \\
\hline
\end{tabular}

\subsection{A Review of Phase I Results}

Because the field of distributed resource benefits is broad and ill-defined, this project began with an initial scoping effort. The preliminary work included a survey of DER owners and/or operators, a collection of case studies, a review of published work, and an exploration of potential analysis methodologies (Poore et al 2002).

The survey covered 162 DER installations, included a broad range of sizes and technologies, and requested information from each system operator regarding their motivation to install the system. Forty-nine installations were subsidized technology demonstration units, typically fuel cells or microturbines. These installations are providing invaluable performance data for the newer technologies, but are less useful in the current examination of DER benefits. A review of the benefits cited by the non-demonstration installations showed that the motivation varies according to the system ownership, as summarized here in Table 2 and Figure 1. Customer and third-party owned systems were most likely installed to take advantage of cogeneration. Utility-owned systems were motivated more often by a desire to reduce peak demands. Other considerations cited less often by survey respondents included fuel, environmental, and market considerations. 
Table 2. DER survey results: motivation for installation of current DER systems according to system ownership class (\%)*

\begin{tabular}{|l|c|c|c|c|}
\hline & $\begin{array}{c}\text { Total } \\
\text { (113 responses) }\end{array}$ & $\begin{array}{c}\text { Customer } \\
\text { (50 responses) }\end{array}$ & $\begin{array}{c}\text { Third Party } \\
\text { (16 responses) }\end{array}$ & $\begin{array}{c}\text { Utility } \\
\text { (37 responses) }\end{array}$ \\
\hline \hline Energy efficiency via cogeneration & 47 & 60 & 81 & 11 \\
Enhanced reliability & 34 & 44 & 25 & 30 \\
Cost reduction & 30 & 44 & 44 & 8 \\
Reduced peak demand & 23 & 12 & 19 & 43 \\
Price protection & 13 & 10 & 0 & 27 \\
Increased capacity & 10 & 10 & 25 & 5 \\
Avoided grid constraints & 8 & 2 & 6 & 16 \\
Burn waste product & 5 & 4 & 13 & 5 \\
Upgrade plant & 5 & 4 & 19 & 0 \\
\hline
\end{tabular}

* Column totals are greater than $100 \%$ because most owners cited multiple reasons.

Figure 1. DER survey results: motivation for installation of current DER systems according to system ownership class

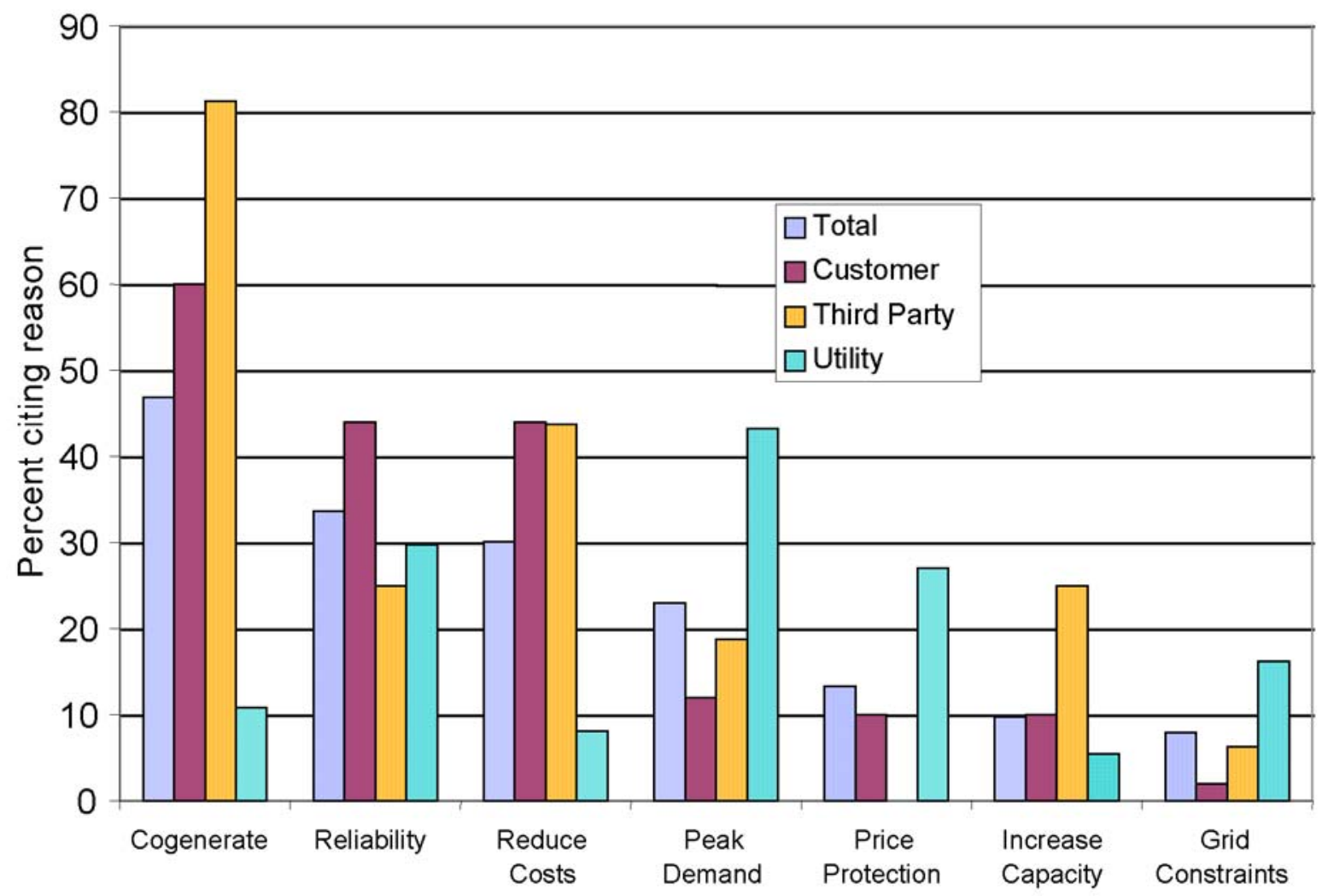

Note that in today's economic environment, there are currently no price signals in PJM to reveal the value of ancillary services that are available from DER, so they would not be included in any owner's list of DER benefits. In addition, the survey respondents were the DER system owner/operators, so this survey instrument would not reveal benefits to other parties.

Four in-depth case studies were made to explore benefits that are typically outside the scope of a DER cost-benefit analysis. For each of these cases, the DER technology, load, and alternative 
utility choices were characterized. The system costs, including both capital and operating expenses were examined. Associated risks, such as the uncertainty of future fuel supplies or shifting environmental regulations were explored. Considering all these factors, the benefits to the system owner/operator, to local utilities, and to other ratepayers were addressed. One of these cases was a clear example of transmission and distribution (T\&D) investment deferral. Another showed how DER could provide critical peak load support to a grid-constrained system, preventing outages to a localized region that extended beyond the DER system owner's boundary. One case study demonstrated a DER system able to provide high reliability that would have otherwise required substantial investments in the local distribution grid. This same case was also a compelling example of the efficiency opportunities available when cogeneration is employed in a DER system. The fourth case was an older PURPA-qualified system. For such systems, environmental and energy conservation benefits are typically balanced against slightly higher costs for ratepayers. However, for the unusual utility economics that occurred during the time period under study, this plant also contributed profits to the local utility.

An updated review of published work in this area found many research efforts that tend to describe these benefits in qualitative terms. However, there has been limited success in placing these benefits on the same economic basis that is already used to define the basic fuel and utility cost effects for the prospective DER installer.

The ultimate goal of Phase I was to define the analysis tools necessary to properly assign values to these 'other' facets of DER benefits. Pertinent observations that should be useful in defining such a tool include:

- DER (excluding the demonstration units) is installed to provide baseload or peak load power:

○ DER installed to meet base load growth or replacement; typically employed cogeneration and were recognized as reducing overall energy costs.

$\circ$ DER installed to meet peak loads, were used by a customer to avoid peak demand charges or by a utility with a need to serve less frequently encountered peak load levels.

- Reliability benefits (cited by $40 \%$ of DER owners, yet no valuation method in use)

$\circ$ back-up power source during a utility power outage.

$\circ$ power quality: providing voltage support or stability, VARs, contingency reserves, and black start capability.

- Economic benefits to society:

- Price stability

○ Reduced infrastructure costs

- Environmental benefits that are complex and may not occur in the same geographical location as the DER:

○ Depends on DER technology, fuel, efficiency

- Depends on displaced central production technology, fuel, efficiency

- Depends on relative locations

Considering the influence of geography on many of these benefits, such as environmental tradeoffs and T\&D deferrals, it would not be appropriate to use a macro-economic national model. Indeed, considering the diversity of these benefits, it may be necessary to use multiple analysis 
tools. A regional model, with a census of available power plants and a comparative technology database, could address the reliability and environmental benefits. A more focused utility economic model may be needed to assess the values of T\&D deferrals and power quality ancillary benefits. With these results in hand, the economic benefits to society could then be evaluated.

\subsection{Analysis Approach}

Three major methods were used to analyze the benefits of DER in this study. In Chapter 2 we used a regional bulk power market model to evaluate the impact of DG on the rest of the electric grid. This provides insight into the generation avoided by DER, and allows for analysis of generation costs, emissions, and reserve requirements. Relative benefits to the DER owner, utility, and society can be evaluated. In Chapter 3 we analyze the embedded and incremental cost of T\&D systems to utilities. This cost data can be combined with the coincident demand reduction attributable to DG to determine the long-term average value for T\&D deferral. In Chapter 4 we conduct an analysis of the avoided DER owner's energy purchases using utility electricity and gas rates. By comparing the savings to the cost of a DER project, an estimate of the relative profitability of the project to the owner is evaluated. 
DER Benefits 


\section{A Regional Analysis of Electricity Supply and Demand}

To model the impact of DG on an area's power system we first must collect the data to define the system, both supply and demand. These data are then converted into a form for use in the model developed for analysis (section 2.1). Appendix A describes the methodology used in modeling the PJM electric system supply and demand and implemented via the ORCED computer code (Hadley et al, 1998). DER generation can be treated as a reduction in system demands, with consequent changes in the load duration curves (LDC's) (section 2.2). Comparing the changes in production provides information on system response to the addition of DG resources (section 2.4.1), including emissions (section 2.4.2), generation reliability (section 2.4.3), ancillary services (section 2.4.4), and costs to utilities (section 2.4.5).

\subsection{Data resources}

To quantify the impact of DER on the power system we have to model that power system both with and without the DER in question. For this study, we chose to model the PJM power pool as it was in 1999, when it contained most of Pennsylvania, New Jersey, Maryland, and Delaware (Figure 2). It is also referred to as the Mid-Atlantic Area Council, one of the reliability councils in the North American Electric Reliability Council. The light-green represents PJM-West which was outside of the control of PJM during 1999.

Figure 2. PJM region including all or parts of Pennsylvania, New Jersey, Maryland, and Delaware.

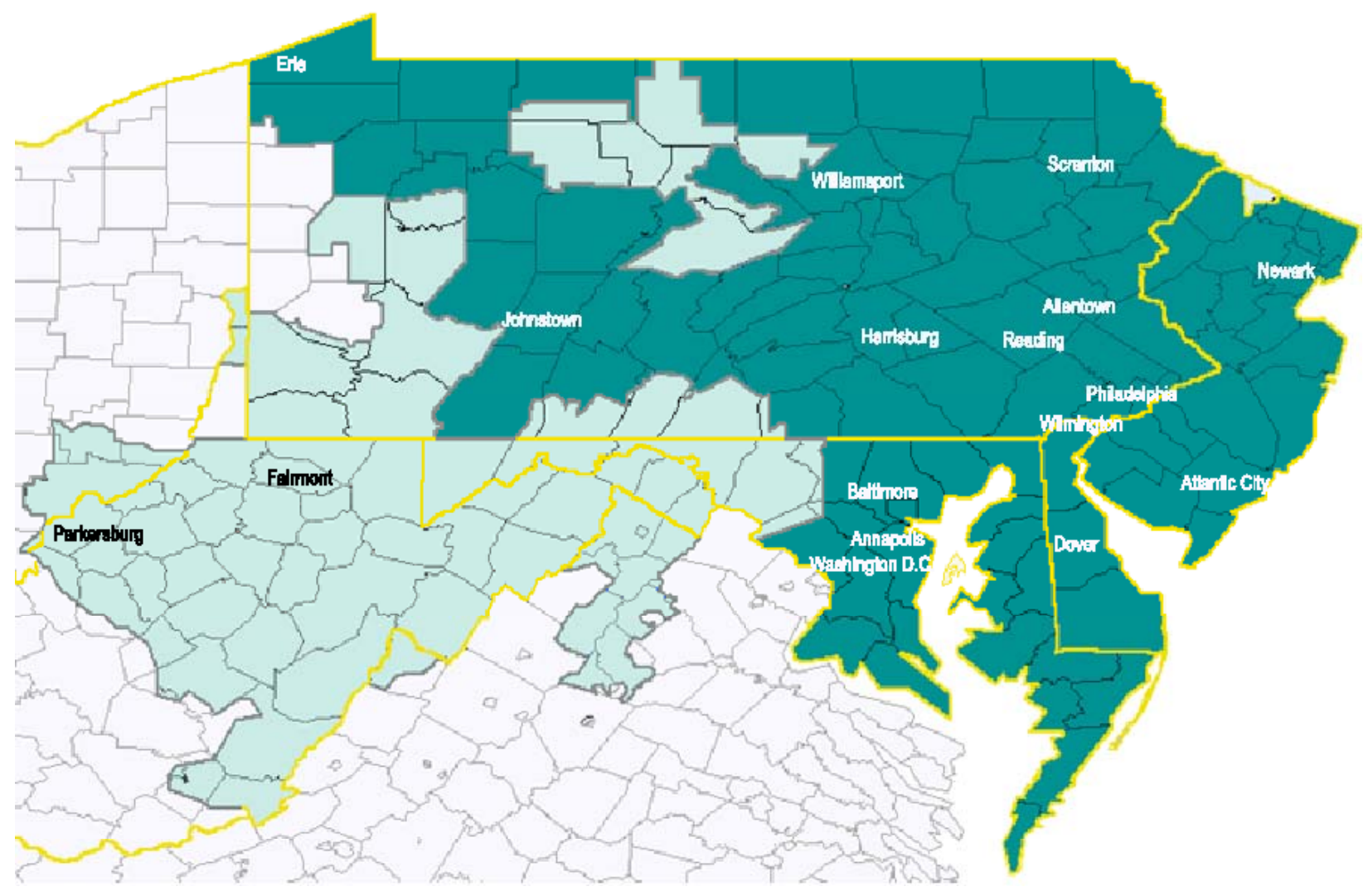


The PJM region has established a wholesale market system that allows power plants and loadserving entities to buy and sell power on an hourly basis. It uses a bidding system to establish real-time prices that are transparent to the market.

We chose to use data for operation of the system from 1999. More recent data are available but not as complete. Also, the years 2000 and 2001 saw great volatility in electricity and fuel prices, which would make it difficult to draw conclusions from a model based on those two years.

\subsubsection{PJM Supply}

The operating and emissions characteristics of each plant in the PJM region must be defined. One of the input files from the Energy Information Administration (EIA) National Energy Modeling System (NEMS) lists over 19,000 power plant units, providing capacity, availability, heat rate, emissions, and date of construction and retirement, among other characteristics. (EIA 2002) (A power plant may have multiple units, and each unit may be further separated in the database if it has multiple owners.) The power plants in the PJM region that were operating in 1999 were pulled from this database, resulting in a list of 775 units with a combined capacity of over 57,000 MW.

Utilities must submit a large amount of financial and operations information to the Federal Energy Regulatory Commission (FERC) and the EIA. Resource Data International collects this publicly available information, categorizes it, performs some quality checks on it, and distributes it in a convenient computer program called Powerdat (Platts 2002). The data for the power plants in PJM were pulled from the database. Not all power plants in the EIA dataset are included in the Powerdat database, and some of the data in Powerdat is recorded for the entire plant rather than for individual units. Nevertheless, the data provides additional details, especially on fuel and operating costs for the year.

A further set of information is available from the Environmental Protection Agency (EPA). It has released a data set for plants used in their Integrated Planning Model (EPA2002). The file includes unit-level data on capacity, heat rate, and emissions rates for $\mathrm{SO}_{2}, \mathrm{NO}_{\mathrm{x}}$, and mercury.

The cost of fuel for each plant is reported in the databases, and the consequent average cost of fuel can be calculated (Table 3 ). Although the model uses the actual reported cost for each plant, the average provides insight into the general prices paid in 1999. Note that in 1999, oil prices were relatively low, compared to natural gas prices. These oil prices are typically low because this oil is mainly residual fuel oil rather than the higher-cost distillate fuel. The result is that oil-fired plants played a significant role in the marginal production for the PJM region in

Table 3. Average PJM 1999 fuel prices

\begin{tabular}{|lc|}
\hline \multicolumn{1}{|c|}{ Fuel } & $\begin{array}{c}\text { Price } \\
\text { (\$/mmBtu) }\end{array}$ \\
\hline \hline Gas & 2.98 \\
Oil & 2.18 \\
Coal & 1.46 \\
Uranium & 0.52 \\
\hline
\end{tabular}
1999. According the Annual Energy Outlook (AEO) 2002 (EIA 2001) the average residual fuel price for electric generation across the nation was $\$ 2.45 / \mathrm{mmBtu}$ in 1999 but increased to $\$ 4.11 / \mathrm{mmBtu}$ in 2000 . Longer-term, the price averages around $\$ 3.50 / \mathrm{mmBtu}$. 
Figure 3. PJM supply curve

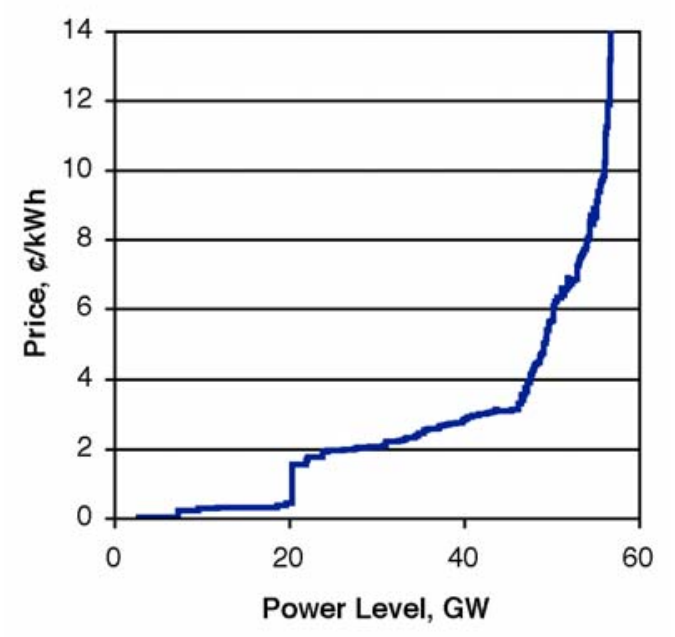

The EIA database showed 775 power plant units in the PJM region. These were consolidated into 200 bins as described in Appendix A. Once the plants were defined, they could be sorted in order of increasing variable cost to create a supply curve for power (Figure 3). The zero price capacity is the nondispatchable generation, followed by the nuclear capacity at around $0.5 \phi / \mathrm{kWh}$. Coal plants report variable cost from $\sim 1.5$ to $3 \phi / \mathrm{kWh}$. Oil and gas plants have variable prices from $\sim 2.5$ to $16 \phi / \mathrm{kWh}$ and beyond. Actual plants have varying efficiencies depending on the fraction of rated capacity at which they are operating, so variable costs will change as the plant loading changes. However, that level of detail is not readily available for plants and was not included in the model.

\subsubsection{PJM Demand}

The other key factor in determining power plant production is defining the demands on the grid. PJM reports their hourly demands, both current and historical, on their website (PJM 2002). Figure 4 shows the hourly change in demands over the year. Note that the highest demands occur in the summertime, due to the air conditioning requirements. Therefore, a peak season between May 1 and September 30 was selected because $\mathrm{NO}_{\mathrm{X}}$ emissions are more heavily regulated in parts of the country during this time. Using this definition allows us to gather more detailed information specific to that season. This hourly data is used to produce a LDC as described in Appendix A.

Figure 4. PJM hourly system demand for 1999

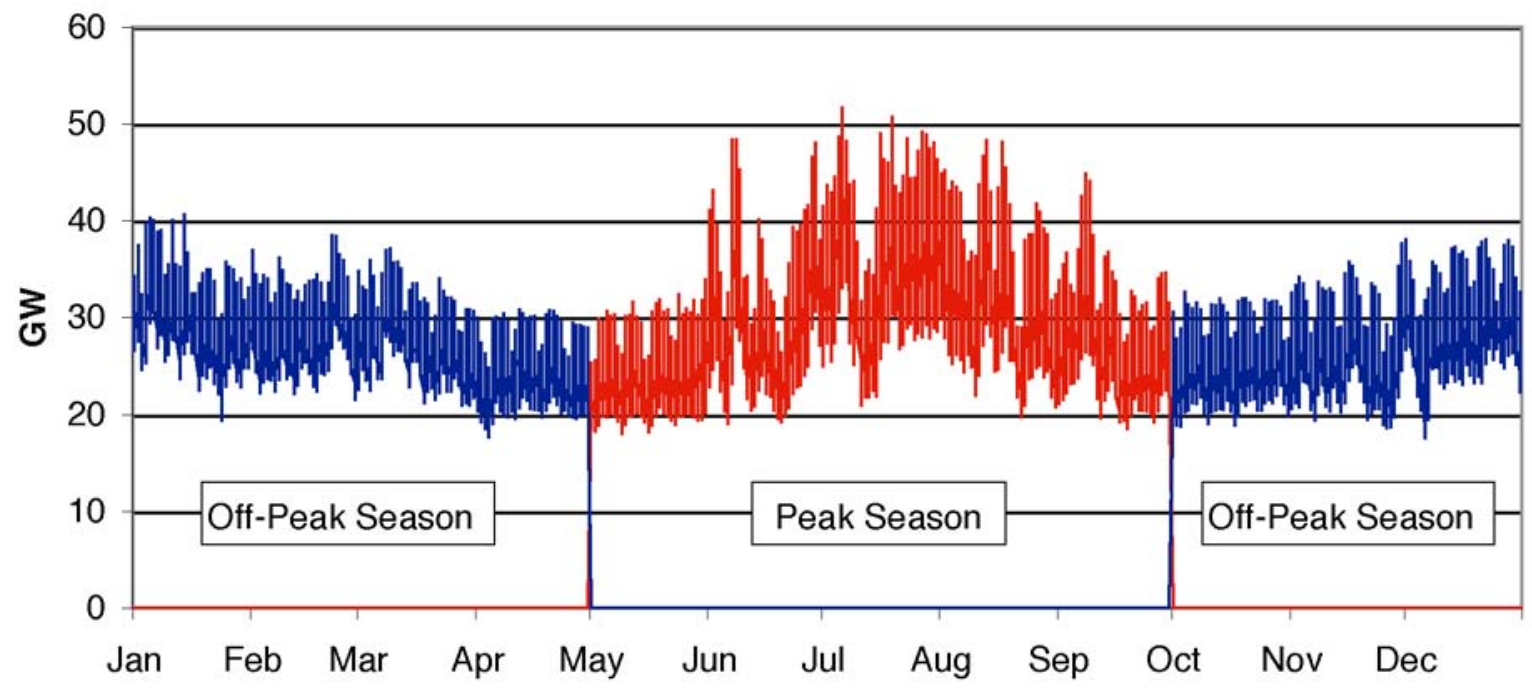




\subsubsection{PJM Prices}

Electric and gas prices are key to the economic attractiveness of DER. The commercial owner faces rates that may be time-dependent or fixed, based on wholesale prices or set by regulators, and based on whether DER is used or not. Individual utilities within PJM may have different rates based on their generating assets, contracts with fuel suppliers or independent generators, and the state regulatory policies.

In this analysis we concentrated on the commercial rates from three of the larger utilities in PJM: Public Service Electric and Gas (PSE\&G), Baltimore Gas and Electric (BG\&E), and Pennsylvania Power and Light (PPL). We used the wholesale electric prices from PJM and the average monthly citygate prices for Pennsylvania, New Jersey, and Maryland for 1999. (Citygate is a point or measuring station at which a distributing gas utility receives gas from a natural gas pipeline company or transmission system.) In addition, ORCED produces marginal and embedded generation prices based on the input costs of production for the plants as described in Appendix A.

Both PSE\&G and BG\&E have time of use prices for commercial customers that vary based on time of day, day of the week, and season of the year. Besides a price based on the amount of energy used, they also have a demand charge that is based on the maximum demand during the period. Table 4 shows the current commercial prices for PSE\&G while Table 5 shows the prices for BG\&E. In addition, there is a temporary 9\% Restructuring Rate Reduction applied to all PSE\&G rates. Pennsylvania Power \& Light's commercial rates include declining blocks, which means prices get lower with additional purchases. This makes it difficult to apply this rate structure within a regional analysis of DER savings because it depends on the quantity of electricity purchased by each customer after the addition of DER.

Table 4. PSE\&G commercial power rates

\begin{tabular}{|lrr|}
\hline & $\begin{array}{c}\text { Energy } \\
\mathbf{c / k W h}\end{array}$ & $\begin{array}{c}\text { Demand } \\
\text { \$/kW-month }\end{array}$ \\
\hline \hline June thru September & & \\
8am to 10 pm Weekdays & 8.23 & 8.76 \\
8am to 10 pm Saturday & 7.21 & 1.17 \\
All other times & 5.58 & 1.17 \\
& & \\
October thru May & & \\
8am to 10 pm Weekdays & 8.23 & 7.61 \\
8am to 10 pm Saturday & 7.21 & 1.17 \\
All other times & 5.58 & 1.17 \\
\hline
\end{tabular}

Standby Cost is $\$ 3.86$ per $\mathrm{kW}$ and is determined by the maximum self-generation capacity that is used
Commercial DER owners would assess the economic value of the DER based upon the net financial effect, which includes not only savings associated with their electricity rates, but also the purchase of additional natural gas for generating purposes. DER owners can buy natural gas either on the open market or from the distributing utilities. Both PSE\&G and BG\&E publish their monthly gas rates. Table 6 shows the commodity prices under the General Services rates (for BG\&E) and for the Cogenerating Facilities purchases of over 600,000 therms (PSE\&G). While prices are similar for most months, there are occasional differences. For our calculation of financial benefits to DER owners, we used the most recent 2002 prices. However, for electrical system changes and impacts on utilities we used 1999 values. 
Table 5. BG\&E commercial power rates

\begin{tabular}{|c|c|c|}
\hline & $\begin{array}{l}\text { Energy } \\
\text { \&/kWh }\end{array}$ & $\begin{array}{c}\text { Demand } \\
\$ / \mathbf{k W} \text {-month }\end{array}$ \\
\hline \multicolumn{3}{|l|}{ June thru September } \\
\hline $\begin{array}{l}7 \mathrm{am} \text { to } 10 \text { am and } 8 \text { to } \\
11 \mathrm{pm} \text {, Weekdays }\end{array}$ & 3.07 & 11.64 \\
\hline 10am to $8 \mathrm{pm}$, Weekdays & 4.26 & 11.64 \\
\hline $\begin{array}{l}11 \mathrm{pm} \text { to } 7 \mathrm{am} \text { weekdays and } \\
\text { all weekend/holiday hours }\end{array}$ & 1.62 & 11.64 \\
\hline \multicolumn{3}{|l|}{ October thru May } \\
\hline $\begin{array}{l}11 \text { am to } 5 \mathrm{pm} \text { Weekdays } \\
7 \text { to } 11 \mathrm{am} \text { and } 5 \text { to } 9 \mathrm{pm}\end{array}$ & 2.24 & 6.02 \\
\hline $\begin{array}{l}\text { Weekdays } \\
\text { 9nm to 7am weekdays and }\end{array}$ & 2.58 & 6.02 \\
\hline all weekend/holiday hours & 1.65 & 6.02 \\
\hline
\end{tabular}

Charges do not include $0.695 \phi / \mathrm{kWh}$ energy and $\$ 2.67 / \mathrm{kW}$-month demand because not avoided by self-generation
Table 6. Gas commodity prices, $\$$ /therm

\begin{tabular}{|crr|}
\hline & PSE\&G & BG\&E \\
\hline Oct-01 & 31.75 & 31.33 \\
Nov-01 & 44.53 & 37.63 \\
Dec-01 & 34.39 & 45.19 \\
Jan-02 & 37.62 & 52.06 \\
Feb-02 & 31.25 & 43.31 \\
Mar-02 & 35.74 & 49.54 \\
Apr-02 & 47.48 & 46.67 \\
May-02 & 47.04 & 47.1 \\
Jun-02 & 47.78 & 46.69 \\
Jul-02 & 46.5 & 46.93 \\
Aug-02 & 41.92 & 42.1 \\
Sep-02 & 46.5 & 46.4 \\
\hline
\end{tabular}

PJM issues the market-clearing wholesale electricity prices for every hour. These prices do not include the costs for transmission, distribution, and service that are included in the commercial prices above. Since we are

simulating the system of 1999 , we used the prices from that year to calculate the electrical savings that the utility would see from generation by DER. Over that same year, natural gas prices also varied. Figure 5 shows the wholesale electric prices by hour and the average citygate gas price for each month. The gas price was found by averaging the monthly citygate price from EIA's Natural Gas Monthly report (EIA 2002b) for Pennsylvania, Maryland, and New Jersey.

Figure 5. PJM average citygate gas price and hourly wholesale electric price

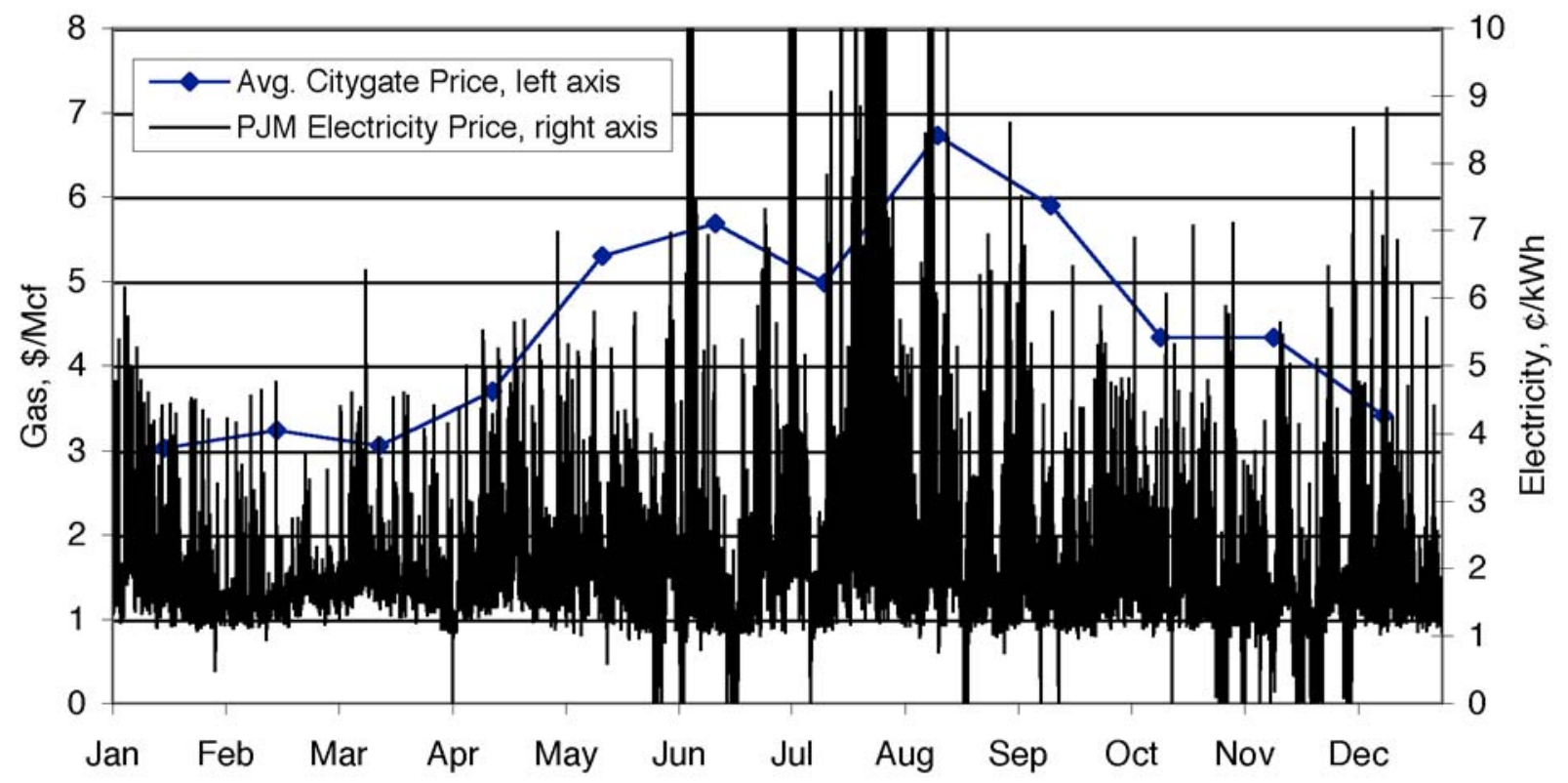




\subsubsection{DER Characterization}

In addition to knowing the change in operations from the system plants, we must calculate the impacts of production from the DG. There are several sources available for DG cost and performance (RDC 2001, Iannucci 2002). For this study, we used the parameters from Iannucci that list technology data for DG available by 2002 (Table 7).

Table 7. Distributed generation technologies

\begin{tabular}{|c|c|c|c|c|c|c|c|}
\hline Technology & Model/ Type & $\begin{array}{l}\text { Size } \\
\text { kW }\end{array}$ & $\begin{array}{c}\text { Capital } \\
\text { Cost } \\
\$ / k W\end{array}$ & $\begin{array}{c}\text { O\&M } \\
\text { Cost } \\
\$ / M W h\end{array}$ & $\begin{array}{l}\text { Electrical } \\
\text { Efficiency }\end{array}$ & $\begin{array}{c}\mathrm{NO}_{\mathrm{x}} \\
\text { emissions, } \\
\text { lb/MWh }\end{array}$ & $\begin{array}{c}\mathrm{CO}_{2} \\
\text { emissions, } \\
\text { lb/MWh }\end{array}$ \\
\hline Fuel Cell-2 & $\begin{array}{l}\text { ONSI PC-25 } \\
\text { / Phos Acid }\end{array}$ & 200 & 5000 & $10^{*}$ & $43 \%$ & 0.0033 & 936 \\
\hline Microturbine-2B & Capstone 60 & 60 & 1093 & 10 & $25 \%$ & 0.541 & 1584 \\
\hline $\begin{array}{l}\text { Combustion } \\
\text { Turbine-2D }\end{array}$ & $\begin{array}{l}\text { Solar Taurus } \\
60\end{array}$ & 5200 & 670 & 13 & $27 \%$ & 1.388 & 1463 \\
\hline $\begin{array}{l}\text { Combustion } \\
\text { Turbine-6D }\end{array}$ & $\begin{array}{l}\text { Solar Taurus } \\
60\end{array}$ & 5200 & 850 & 15 & $27 \%$ & 0.278 & 1463 \\
\hline $\begin{array}{l}\text { Combustion } \\
\text { Turbine-6B }\end{array}$ & $\begin{array}{l}\text { Solar Mars } \\
90\end{array}$ & 9450 & 785 & 15 & $29 \%$ & 0.263 & 1391 \\
\hline $\begin{array}{l}\text { Natural Gas } \\
\text { Engine-2C }\end{array}$ & $\begin{array}{l}\text { Cummins } \\
\text { QSV/QSK }\end{array}$ & 330 & 670 & 9.7 & $34 \%$ & 2.37 & 1166 \\
\hline $\begin{array}{l}\text { Natural Gas } \\
\text { Engine-6C }\end{array}$ & $\begin{array}{l}\text { Cummins } \\
\text { QSV/QSK }\end{array}$ & 1750 & 870 & 11.5 & $34 \%$ & 0.25 & 1166 \\
\hline
\end{tabular}

* $+\$ 10 / \mathrm{kW}$-year fixed O\&M cost

Source: lannucci 2002

The electrical efficiency determines the amount of fuel input required for the electricity output. This influences the amount of carbon that is emitted and the amount of thermal needs that can be provided by the technology if CHP is used. Besides the operating and maintenance (O\&M) costs shown, the DER project will have to purchase fuel. The fuel cell has a fixed O\&M cost of $\$ 10 / \mathrm{kW}$-year as well as a variable O\&M cost of $\$ 10 / \mathrm{MWh}$.

If CHP is used so that steam generation from boilers is displaced, then the emissions of the boiler can be subtracted along with the displaced electricity generation. (We use boilers as an example, but the DG site's thermal needs could be in the form of hot water or some other thermal requirement.) Boiler emissions

Table 8. Heat exchanger efficiencies of CHP technologies

\begin{tabular}{|lccc|}
\hline Technology & $\begin{array}{c}\text { Heat } \\
\text { Exchanger } \\
\text { Efficiency }\end{array}$ & $\begin{array}{c}\text { Electrical } \\
\text { Efficiency }\end{array}$ & $\begin{array}{c}\text { Total } \\
\text { Efficiency }\end{array}$ \\
\hline Fuel Cell & $50 \%$ & $43 \%$ & $71 \%$ \\
Microturbine & $67 \%$ & $25 \%$ & $75 \%$ \\
Combustion Turbine & $62 \%$ & $27 \%-29 \%$ & $72 \%-73 \%$ \\
Natural Gas Engine & $52 \%$ & $34 \%$ & $68 \%$ \\
Non-CHP Boiler & $72 \%$ & & $72 \%$ \\
\hline
\end{tabular}

Source: Calculated from product literature from ONSI, Unifin, Solar Turbines, and Fairbanks Morse. Electrical efficiencies from Table 7.

will vary depending on the age and type of boiler. If we assume they have similar characteristics to gas-fired steam electric generators, then we can find the average $\mathrm{NO}_{\mathrm{X}}$ emissions from the EIA and EPA data. The total $\mathrm{NO}_{\mathrm{X}}$ emissions for gas-fired steam plants are 208 tons and heat input is 
4.05 TBtu. This gives an emission rate of $0.102 \mathrm{lb} \mathrm{NO} / \mathrm{mmBtu}$. (The capacity of gas-fired steam plants in PJM is only $350 \mathrm{MW}$, with a capacity factor of $12 \%$. Using all gas-fired electric plants changes the average emission rate slightly to $0.11 \mathrm{lb} \mathrm{NO} / \mathrm{mmBtu}$.) Industrial boilers may have lower emissions than steam electric boiler because of operations at lower temperatures (which limits $\mathrm{NO}_{\mathrm{X}}$ formation) or higher because of poorer efficiencies.

Heat exchanger efficiencies are dependent on the difference between the temperature of the exhaust and the temperature of the thermal load. The exhaust temperature depends on both the technology used and the efficiency of the electrical conversion. Fuel cells and engines typically have lower exhaust temperatures than turbines, and the energy is not as readily captured for other end-uses. Steam boilers are typically more efficient (or effective) in converting fuel input to heat output than CHP units and we will assume a thermal efficiency (or effectiveness) of the boiler of $72 \%$ (ratio of useful energy out to energy in), while the efficiency of the boiler portion of the CHP depends on the type of technology (Table 8). Combined, the electrical and thermal efficiency for the DG technologies when using CHP is between $68 \%$ and $79 \%$ [total efficiency $=$ electrical efficiency + thermal efficiency x $(1-$ electrical efficiency)]. These values may appear low compared to other literature, but these values are based on the higher heating value of gas rather than lower heating value (which does not include recovery of the latent heat of vaporization in the input.) Using the lower heating value raises the apparent efficiency approximately $10 \%$. (The efficiency of both conventional and CHP boilers is also a function of the thermal load's temperature requirements.)

As DG is used to displace system demand, the load shapes change and the LDC's need to be recalculated. For this study, we considered two DG deployment options: a weekday only system that ran from 8am to 8pm (henceforth called Peaking DG), and a system that ran $100 \%$ of the time (called Baseload DG). We added only $100 \mathrm{MW}$ of DG, large enough that it would be differentiable on the LDC, yet small enough that we could avoid making changes to the system capacity by retiring additional plants or not building some new capacity. This gave a picture of which plants would be called upon less often due to the DG, without having to prejudge which capacity would be reduced. The LDC's shown in Figure A-3 were recalculated after reducing the system demands in accordance with the hours that the DER would operate.

Modeling DG as a reduction in load rather than an addition to the power supply implies that the customer controls the DG and decides what hours it should run. If the utility or system operator were controlling the DG, or if the customer was trying to sell the production on the wholesale market, then the DG would be dispatched as other plants based on its variable cost or bid price. The variable cost will depend on several factors, most notably the gas price, the technology used, and whether the thermal exhaust is used. Using the parameters of the technologies above, Figure 6 shows the variable cost of the electricity. If CHP is used, then the savings in boiler fuel offsets some of the cost so that the remaining electricity cost is reduced. The addition of CHP can greatly change the variable cost. Microturbines change from the highest variable cost without $\mathrm{CHP}$, at around $\$ 63 / \mathrm{MWh}$ with a $\$ 4 / \mathrm{mmBtu}$ gas price, to the lowest cost at $\$ 26 / \mathrm{MWh}$ with CHP. This is because of their combination of relatively low electrical efficiency but high utilization of thermal energy. At a variable cost of $\$ 26 / \mathrm{MWh}$, the DER would be dispatched within the system roughly $48 \%$ of the year, while at $\$ 63 / \mathrm{MWh}$ it would only be called upon $1 \%$ of the year. 
Figure 6. DER electricity variable cost as function of gas price, $\$ / M W h$

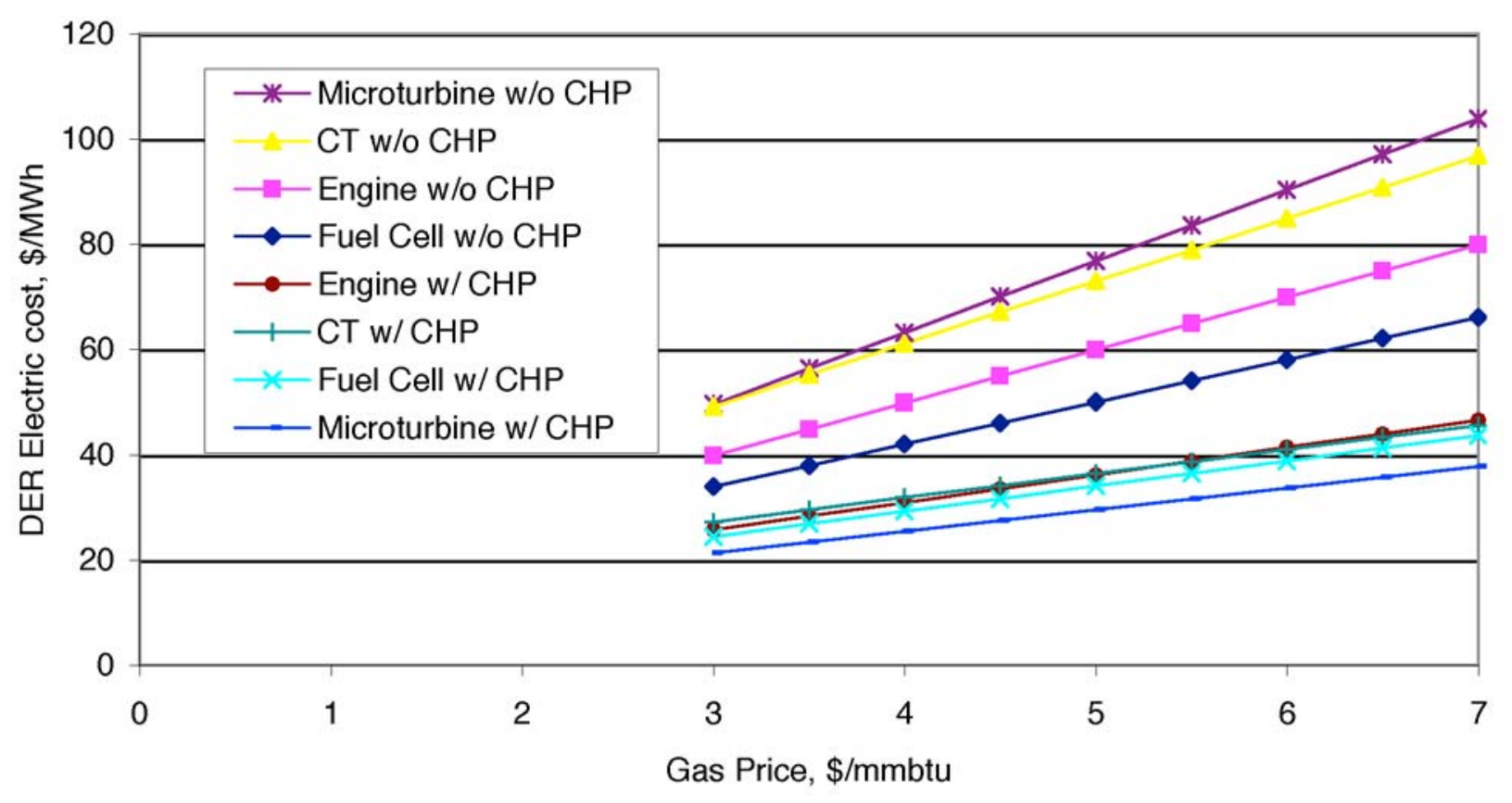

\subsection{DER Scenario Definitions}

To explore the two deployment options mentioned above, three basic scenarios were defined: a base case with no DG, one with $100 \mathrm{MW}$ of DG running $100 \%$ of the time, and one with 100 MW of DG running from 8 am to $8 \mathrm{pm}$ Monday through Friday. The system loads in the appropriate hours were reduced by $100 \mathrm{MW}$ and new LDC's were calculated. We then ran ORCED with the new curves to determine the changes in operation of all of the plants.

The addition of DER to a system could be modeled from either a supply increase or a demand reduction point of view. There are two main arguments for using the demand reduction approach. First, the DG is typically on the customer side of the meter, so from the grid's point of view it appears as a reduced demand for that customer. Second, the utility typically has little or no control over the resource, which is again characteristic of a demand, or load.

To determine the cost of the demand reduction to the utility (and the prices paid to the DG operator if he sold power on the wholesale market) we correlated the price curve from the base case to the LDC and found the wholesale price for each hour of the year. We performed a similar calculation with the reserves price curve from ORCED so that the DG may earn revenues as a source of reserves in the hours it is not operating. (Because ORCED uses a probabilistic dispatch algorithm on some plants, the correlation between customer demand and system demand is not $100 \%$, but should be close.)

\subsection{Reserves Market addition to ORCED}

ORCED has been in use for a number of years, with capabilities added as new studies require. A major addition to the model for this study was adding a calculation of a "reserves market" that establishes both an hourly price for certain plants to be available to provide power, and which plants receive that price. ORCED models the reserves by calculating the additional capacity 
needed in each block of time over the year based on an input percentage of demand. (ORCED subdivides each season into over 200 smaller periods, of varying lengths of time, where demand is kept constant for the interval.) Plants that were not called upon for the energy market because their variable costs were too high are assigned to meet the reserves. However, for spinning or supplemental reserves these plants must run at some minimum level, e.g., 10\% of capacity. That minimum capacity requirement, in turn, will cause plants that would otherwise have run to reduce their power level. However, as they back down in energy, they free up the equivalent amount of reserves since they could ramp back up to provide the power in the event of an emergency.

Figure 7. Example electricity demand of 3300 This methodology is shown in Figure 7. MW and 7\% reserves requirement

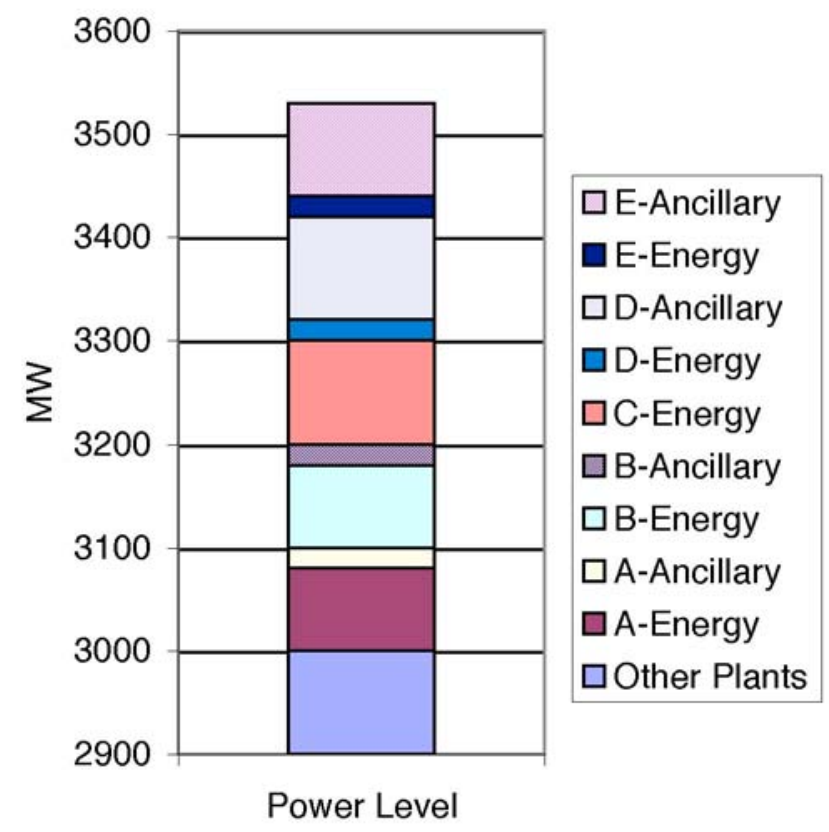
For example, if the demand for energy is $3300 \mathrm{MW}$ at some given time, plants will bid into the market until that demand is met. In this example, the last plant needed to meet demand, and thereby the marginal plant, is Plant C. If the system needs $7 \%$ of demand for reserves, then another $230 \mathrm{MW}$ are needed and can be provided by plants $\mathrm{D}$ and $\mathrm{E}$. However, each of them has minimum running levels of $20 \mathrm{MW}$ in order to have the rest of their capacity available. Therefore, plants $\mathrm{A}$ and $\mathrm{B}$ must lower their power level by a combined 40 MW. (Plant $\mathrm{C}$ could also lower its power, but because it is the marginal plant and sets the price, additional complications are introduced in the analysis.) In this example, plant B cannot lower its power more than $20 \mathrm{MW}$ because it cannot provide much in the way of reserves. It may have a slow ramp rate, or cannot quickly change its power level. Plant A must also be called upon to reduce power and provide 20 MW of reserves.

We modeled the amount of reserves available and minimum power level for each plant by defining two percentages of capacity, based on the plant's technology (Table 9). The minimum running capacity is the percentage of capacity that the plant has to run at before it can supply any reserves to the market. This would define the amount of energy provided by plants $\mathrm{D}$ and $\mathrm{E}$ in the example above. The maximum reserve is the maximum percentage of its capacity that it can provide as reserves if the plant is running. This would define the amounts that plants A and B could be reduced to compensate for the added energy generated by plants $\mathrm{D}$ and $\mathrm{E}$, and are marked as A-Ancillary and B-Ancillary above. The values in the table are based on a general understanding of the technologies involved. Steam plants have higher minimum capacities and cannot shift production as fast as combustion turbines. Combined cycle plants, being a mix of both combustion turbines and steam turbines, have the same minimum capacity as combustion turbines and a total reserve capability somewhere between combustion turbines and steam 
turbines. Nuclear plants are almost always baseload plants that do not load-follow. However, in extreme cases they may be called upon to reduce power a small amount

In addition, the need for reserves causes the system operator to call upon plants D and E to provide power, even though their marginal cost is higher than the market price based on Plant $\mathrm{C}$. Rather than have the entire energy market price raised to the cost of these plants, we treated their minimum run amounts as must-run and they receive their marginal cost regardless of the market-clearing price for energy.

Over the year, different sets of plants will be called upon to either provide reserves or back down their production to satisfy overall energy needs. The extra costs involved are collected for each period and charged to customers.

The market value of the reserves was also calculated. If a plant reduces its electrical output then it foregoes the profit that is the difference between its variable cost and the market-clearing price. The last plant that backs down has the biggest difference between the two and so sets the market price for ancillary services. In the example, if Plant A has marginal costs of $3 \phi / \mathrm{kWh}$ and the marginal cost of Plant $\mathrm{C}$ is $3.5 \phi / \mathrm{kWh}$ then Plant $\mathrm{A}$ is losing $0.5 \phi / \mathrm{kWh}$ on the $20 \mathrm{MW}$ it has to reduce. Therefore, $0.5 \phi / \mathrm{kWh}$ is the market price for reserves that plants $\mathrm{A}, \mathrm{B}, \mathrm{D}$, and $\mathrm{E}$ receive for the reserves they provide during that time. Opportunity costs as modeled in ORCED dominate the cost of supplying reserves but there are other costs as well (Hirst and Kirby 1997).

A separate issue involves the consumption of ancillary services as opposed to supply. Different customers impose different ancillary service burdens on the power system. To avoid cross subsidies customers should be charged for ancillary services based upon the ancillary service burden they place upon the power system. (Kirby and Hirst 2000). To date, however, utilities charge for ancillary services based upon the customer's energy consumption rather than based upon their ancillary service consumption. The modeling here is concerned with supplying ancillary services, notably operating reserves, rather than how these costs are allocated to customers.

\subsection{Results}

Following the definition of each major scenario, the ORCED model was run and results saved. A separate workbook was created that compares the system results for the different ORCED scenarios and calculates the costs and operations of the DER systems in conjunction with the changed system characteristics. This allows a total comparison incorporating both system and DER costs and emissions. The following six sections describe different facets of the consolidated analysis: system changes, emissions changes, reliability, reserves ancillary service markets, costs to utilities, and sensitivities. 


\subsubsection{System Changes}

The key results for the system operations from ORCED are shown in Table 10 and Table 11. A key factor is the percentage of time different types of plants are on the margin. Even though oilfired capacity is only $7 \%$ of total generation, it is on the margin $34 \%$ of the time. Natural gas is on the margin only $14 \%$ of the time while coal is the marginal source $52 \%$ of the year. The rationale behind these values is described in Appendix A in Figure A-4. At the lower parts of the LDC, coal plants solely are on the margin, while in the mid-range and peak periods coal, oil, and gas plants are interspersed depending on their marginal cost. Note that low-variable cost units such as nuclear, or non-dispatchable units, such as renewables, are never on the margin.

Table 10. Production statistics from ORCED base case with no DER

\begin{tabular}{|lrrrrrr|}
\hline & Capacity & $\begin{array}{c}\text { \% of Total } \\
\text { Capacity }\end{array}$ & $\begin{array}{c}\text { Generation } \\
\text { TWh }\end{array}$ & $\begin{array}{c}\text { \% of Total } \\
\text { Generation }\end{array}$ & $\begin{array}{c}\text { Capacity } \\
\text { Factor }\end{array}$ & $\begin{array}{c}\text { \% of Time on } \\
\text { Margin }\end{array}$ \\
\hline \hline Oil St & 8,049 & $14 \%$ & 17.6 & $7 \%$ & $25 \%$ & $30 \%$ \\
Oil CT & 3,746 & $7 \%$ & 1.0 & $0 \%$ & $3 \%$ & $4 \%$ \\
Gas ST & 350 & $1 \%$ & 0.3 & $0 \%$ & $10 \%$ & $1 \%$ \\
Gas CT & 4,079 & $7 \%$ & 1.2 & $0 \%$ & $3 \%$ & $5 \%$ \\
Gas CC & 4,619 & $8 \%$ & 18.9 & $7 \%$ & $47 \%$ & $8 \%$ \\
Nuclear & 12,977 & $23 \%$ & 97.2 & $37 \%$ & $85 \%$ & $0 \%$ \\
Coal & 19,840 & $35 \%$ & 115.9 & $45 \%$ & $67 \%$ & $52 \%$ \\
Hydro & 2,933 & $5 \%$ & 3.6 & $1 \%$ & $14 \%$ & $0 \%$ \\
Renewable & 564 & $1 \%$ & 4.1 & $2 \%$ & $82 \%$ & $0 \%$ \\
\hline Totals & 57,157 & $100 \%$ & 259.7 & $100 \%$ & $52 \%$ & $100 \%$ \\
\hline
\end{tabular}

Table 11. Emissions statistics from ORCED base case with no DER

\begin{tabular}{|lrrrrrrrr|}
\hline & $\begin{array}{r}\text { Energy } \\
\text { In, TBtu }\end{array}$ & $\begin{array}{r}\text { Carbon } \\
\text { kTonne }\end{array}$ & $\mathbf{S O}_{\mathbf{2}} \mathbf{k T o n}$ & $\begin{array}{c}\mathbf{S O}_{2} \\
\mathbf{l b} / \mathbf{m m B t u}\end{array}$ & $\begin{array}{c}\mathbf{S O}_{2} \\
\mathbf{l b} / \mathbf{M W h}\end{array}$ & $\begin{array}{c}\mathbf{N O}_{\mathbf{x}} \\
\mathbf{k T o n}\end{array}$ & $\begin{array}{c}\mathbf{N O}_{\mathbf{x}} \\
\mathbf{l b} / \mathbf{m m} \text { Btu }\end{array}$ & $\begin{array}{c}\mathbf{N O}_{\mathbf{x}} \\
\mathbf{l b} / \mathbf{M W h}\end{array}$ \\
\hline \hline Oil St & 187 & 4,025 & 75.6 & 0.81 & 8.60 & 18.5 & 0.20 & 2.10 \\
Oil CT & 12 & 255 & 0.0 & 0.00 & 0.00 & 0.8 & 0.13 & 1.49 \\
Gas ST & 3 & 50 & 0.1 & 0.06 & 0.67 & 0.17 & 0.10 & 1.14 \\
Gas CT & 13 & 182 & 0.1 & 0.01 & 0.15 & 0.7 & 0.11 & 1.16 \\
Gas CC & 178 & 2,582 & 0.0 & 0.00 & 0.00 & 9.9 & 0.11 & 1.05 \\
Nuclear & 973 & 0 & 0.0 & 0.00 & 0.00 & 0.0 & 0.00 & 0.00 \\
Coal & 1,166 & 29,985 & $1,074.7$ & 1.84 & 18.54 & 261.1 & 0.45 & 4.50 \\
Hydro & 1 & 0 & 0.0 & 0.00 & 0.00 & 0.0 & 0.00 & 0.00 \\
Renewable & 66 & 0 & 0.3 & 0.01 & 0.15 & 0.5 & 0.02 & 0.25 \\
\hline Totals & 2,599 & 37,078 & $1,150.8$ & & & 291.9 & & \\
\hline
\end{tabular}

Running ORCED using the demand curves with the peaking and baseload DER gives results slightly different from the tables above. Since we only dropped demand by $0.2 \%$, little change would be expected in the tables showing total values. However, taking the difference between the cases with and without DER allows the marginal changes to become apparent.

Table 12 and Figure 8 show how much each of the major types of plants are reduced depending on whether the DG operates during the peaking period or all of the year. In the peaking mode, it displaces more oil and gas generation (43\% and $23 \%$ ), while baseload operation results in displacing more coal (52\%). The peaking plants displaced have lower average efficiency than the average of all plants displaced over the year by the baseload DG (31\% vs. $32 \%)$, which is in line 
with the idea that peaking plants are typically higher cost because they are less efficient (besides using more expensive fuel). However, since these plants are more heavily weighted towards gas and oil, they emit less $\mathrm{CO}_{2}$ than the average of all of the plants displaced by the baseload DG. $\mathrm{NO}_{\mathrm{X}}$ and $\mathrm{SO}_{2}$ emissions displaced are lower per MWh for peaking because the coal plants have relatively higher emissions than the gas and oil plants.

Figure 8. Displaced energy by Peak and Baseload DG

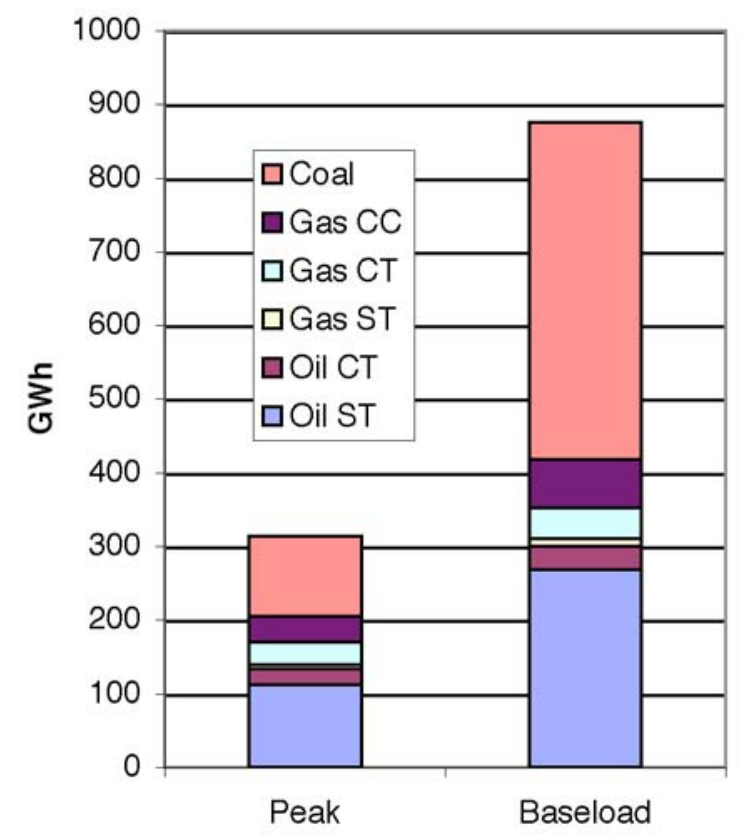

Table 12. Displaced system power parameters

\begin{tabular}{|lrr|}
\hline & $\begin{array}{c}\text { Peaking } \\
\text { DG }\end{array}$ & $\begin{array}{c}\text { Baseload } \\
\text { DG }\end{array}$ \\
\hline \hline Displaced Energy, GWh & 313 & 876 \\
Displaced Source & & \\
$\quad$ Oil ST & $36 \%$ & $31 \%$ \\
Oil CT & $7 \%$ & $4 \%$ \\
Gas ST & $2 \%$ & $1 \%$ \\
Gas CT & $10 \%$ & $5 \%$ \\
$\quad$ Gas CC & $11 \%$ & $8 \%$ \\
Coal & $35 \%$ & $52 \%$ \\
Avg Displaced Efficiency & $31 \%$ & $32 \%$ \\
NO $_{\mathbf{x}}$ Ib/MWh & 3.03 & 3.59 \\
SO $_{2}$, Ib/MWh & 9.67 & 13.1 \\
CO $_{2}$, Ib/MWh & 1,938 & 1,972 \\
Avg. Marginal Cost $\mathbf{c} / \mathbf{k W h}$ & 2.99 & 2.62 \\
Avg. PJM Wholesale & & \\
Purchase Price, $\boldsymbol{\phi} / \mathbf{k W h}$ & 4.43 & 2.83 \\
\hline
\end{tabular}

The average marginal costs also reflect the higher cost of the displaced peaking plants, with peaking plants costing on average $2.99 \notin / \mathrm{kWh}$ versus $2.62 \notin / \mathrm{kWh}$ for displaced plants from baseload DG. This marginal cost will vary over the year, depending on which plants are displaced. Figure 9 shows the LDC for each season with the corresponding marginal cost curve. (With or without the DER included, the LDC will look the same since $100 \mathrm{MW}$ is less than $0.2 \%$ of the system peak demand of 51,000 MW.) Most of each season the price stays below $3 \notin / \mathrm{kWh}$, but when the system demand is at its greatest, i.e., from 0 to $10 \%$ of the LDC for each season, the price rises rapidly, both because production is more expensive and start-up costs for plants (which are factored into their bids) become a more significant factor.

The reserve prices in Figure 9 refer to the payment made for having production available in standby, both by backing down operating plants or contracting for ancillary reserves from plants not selected for production. The methodology used was discussed in Section 2.3. Table 12 also shows the average purchase prices for the DG power using the published prices for 1999 by PJM, reflecting the prices during the hours that the DG would be operating. These published prices are somewhat higher than the ORCED marginal cost because of the unusually high peak prices (up to $99.9 \phi / \mathrm{kWh}$ ) during the summer months and a greater variation in marginal prices (Figure 10). ORCED uses a single average heat rate and consequent marginal cost for each plant, while actual plants will have marginal costs that vary depending on their load level. Also, PJM interactions with other regions may provide supplies at lower prices or demands that raise prices. Furthermore, plants may vary their bid prices to take advantage of market conditions. 
Figure 9. Energy prices, reserves prices, and power level for each season from ORCED

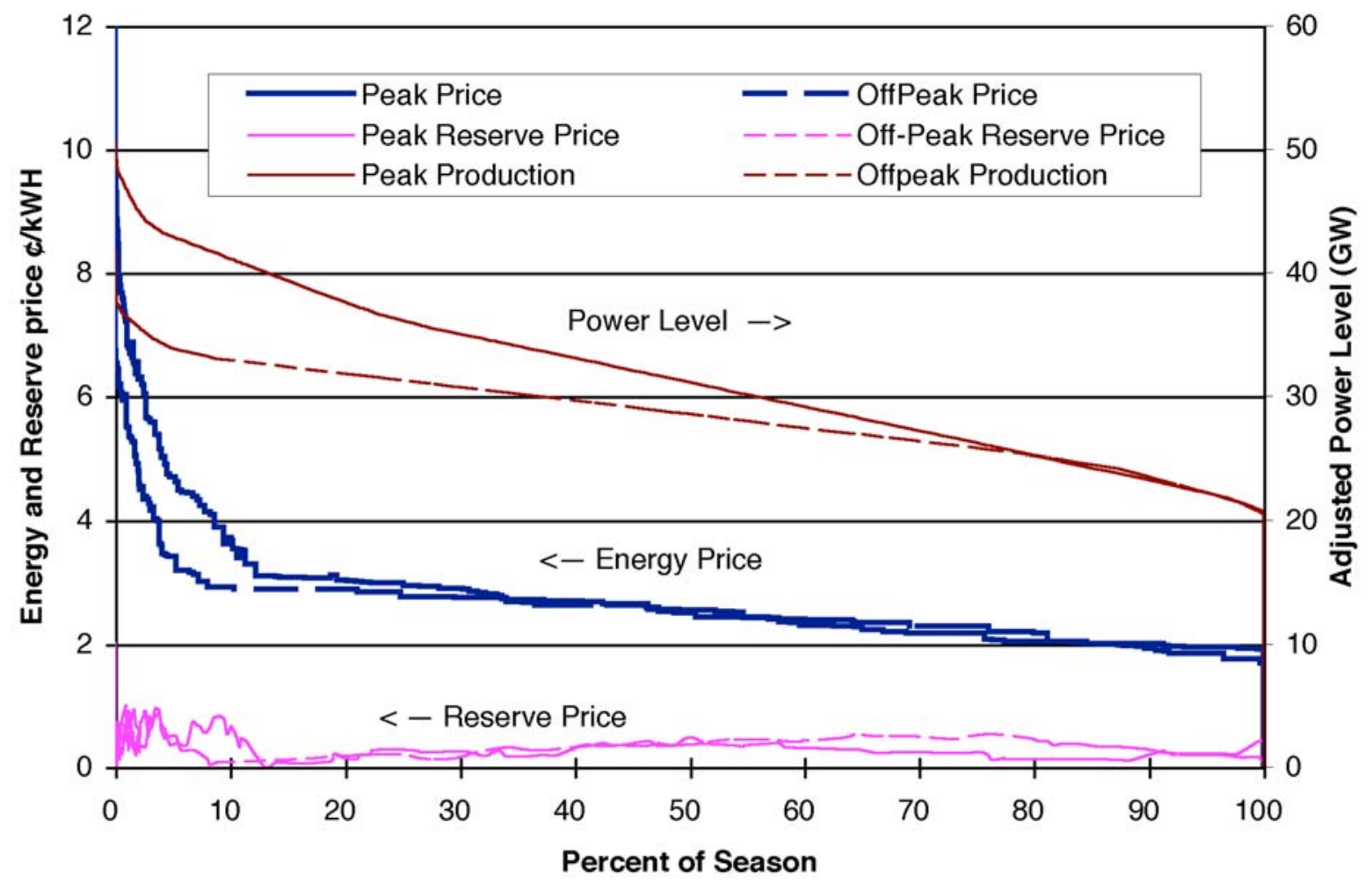

Figure 10. PJM 1999 electricity wholesale prices and corresponding prices from ORCED. PJM prices reached $99.9 \notin / \mathrm{kWh}$, beyond the scale of the chart in the summer months.

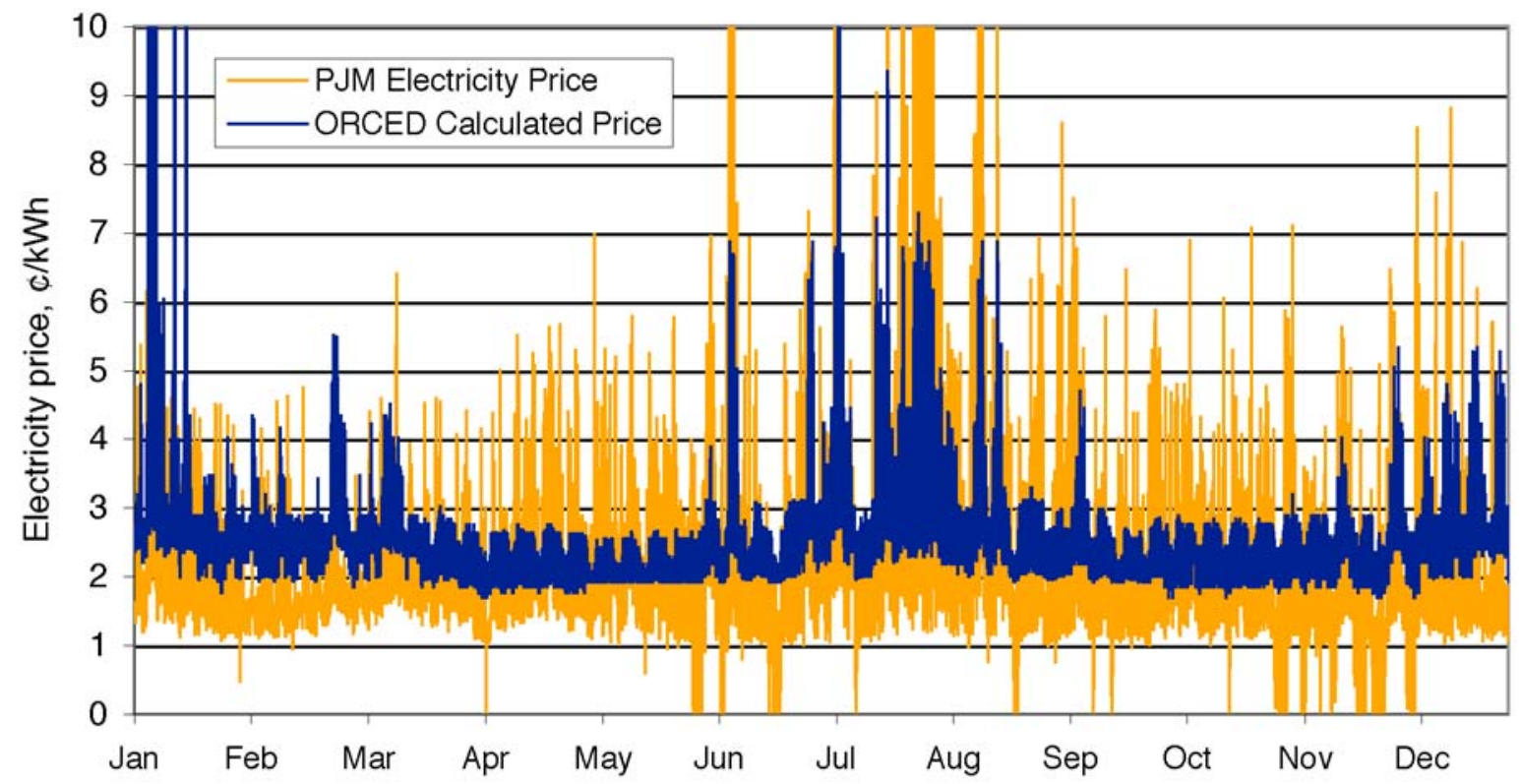




\subsubsection{Emissions Changes}

The net emissions from the DER will depend not only on the amount displaced on the generation system (above) but on the emissions of the DER system itself. These will depend on the type of technology used for the DER because of different efficiencies from the DG. If the DG also operates as CHP then there are additional savings because of the reduction in industrial boiler emissions, but again the amount will depend on the technology because of the efficiency and quality of heat from the DER.

Table 13 and Figure 11 show the emissions generation of $\mathrm{CO}_{2}$ and $\mathrm{NO}_{\mathrm{x}}$ if a Combustion Turbine-6B (as listed in Table 7) is used to represent the DER technology. These emissions are compared to the reductions from displaced power. Table 13 also shows the net $\mathrm{SO}_{2}$ emissions as well; the DG technology burns natural gas and so emits essentially zero $\mathrm{SO}_{2}$. The projected $\mathrm{NO}_{\mathrm{x}}$ emissions are much lower for the turbine CT-6B $(0.26 \mathrm{lb} / \mathrm{MWh})$ than the average emissions that are displaced ( $>3 \mathrm{lb} / \mathrm{MWh}$ ) so net emissions are negative (i.e., the level of emissions is reduced).

Table 13. $\mathrm{CO}_{2}, \mathrm{NO}_{\mathrm{x}}$, and $\mathrm{SO}_{2}$ emissions reductions from $100 \mathrm{MW}$ of Combustion Turbine6B with and without $\mathrm{CHP}$

\begin{tabular}{|c|c|c|c|c|c|c|}
\hline & & Dist. Gen. & $\begin{array}{l}\text { Electric } \\
\text { System }\end{array}$ & $\begin{array}{c}\text { Net w/o } \\
\text { CHP }\end{array}$ & $\begin{array}{l}\text { Thermal } \\
\text { System }\end{array}$ & Net w/ CHP \\
\hline $\mathrm{CO}_{2}, \mathrm{kTons}$ & \begin{tabular}{|l} 
Peaking DG \\
Baseload DG
\end{tabular} & $\begin{array}{l}218 \\
609\end{array}$ & $\begin{array}{l}-304 \\
-864\end{array}$ & $\begin{array}{r}-86 \\
-255\end{array}$ & $\begin{array}{l}-134 \\
-374\end{array}$ & $\begin{array}{l}-219 \\
-629\end{array}$ \\
\hline $\mathrm{NO}_{\mathrm{x}}$, Tons & $\begin{array}{l}\text { Peaking DG } \\
\text { Baseload DG }\end{array}$ & $\begin{array}{r}58 \\
163\end{array}$ & $\begin{array}{r}-491 \\
-1583\end{array}$ & $\begin{array}{r}-433 \\
-1419\end{array}$ & $\begin{array}{r}-526 \\
-1471\end{array}$ & $\begin{array}{r}-958 \\
-2890\end{array}$ \\
\hline $\mathrm{SO}_{2}$, Tons & $\begin{array}{l}\text { Peaking DG } \\
\text { Baseload DG }\end{array}$ & $\begin{array}{l}0 \\
0\end{array}$ & $\begin{array}{l}-1515 \\
-5736\end{array}$ & $\begin{array}{l}-1515 \\
-5736\end{array}$ & $\begin{array}{l}0 \\
0\end{array}$ & $\begin{array}{l}-1515 \\
-5736\end{array}$ \\
\hline
\end{tabular}

Figure 11. Net $\mathrm{CO}_{2}$ and $\mathrm{NO}_{\mathrm{x}}$ emissions from $100 \mathrm{MW}$ of Combustion Turbine-6B w/o CHP

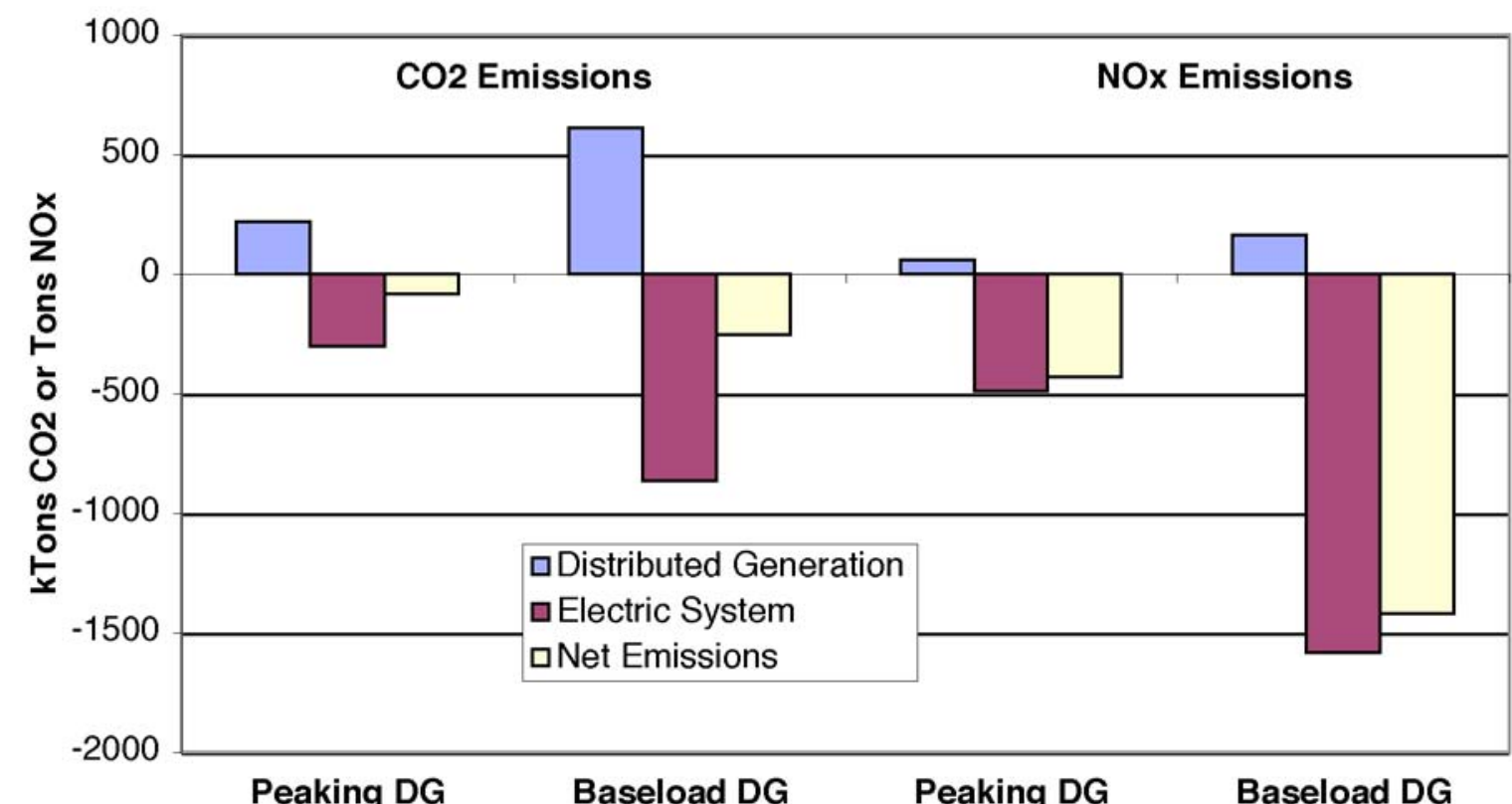


All of the DG technologies listed in Table 7 show significantly lower $\mathrm{NO}_{\mathrm{x}}$ emissions than the displaced power. Table 14 shows the net savings for each technology when subtracting the system emissions. The cleanest technology is the fuel cell, especially for $\mathrm{CO}_{2}$, because of its rated high efficiency. It is noteworthy that other low-NOX technologies are able to achieve over $90 \%$ of the savings that the super-low-NOx fuel cell does.

Table 14. Net emissions savings from $100 \mathrm{MW}$ of different DG technologies w/o CHP

\begin{tabular}{|c|c|c|c|c|c|c|c|c|}
\hline \multirow{2}{*}{$\begin{array}{c}\text { Technology } \\
\text { (Technology lb NO } / \mathrm{MWh} \text { ) }\end{array}$} & \multicolumn{4}{|c|}{ Peaking DG } & \multicolumn{4}{|c|}{ Baseload DG } \\
\hline & kTon & $\begin{array}{l}\mathrm{O}_{2} \\
\mathrm{lb} / \mathrm{MWh}\end{array}$ & Ton & $\begin{array}{l}\mathrm{NO}_{\mathrm{x}} \\
\mathrm{lb} / \mathrm{MWh}\end{array}$ & kTon & $\begin{array}{l}\mathrm{O}_{2} \\
\mathrm{lb} / \mathrm{MWh}\end{array}$ & Ton & $\begin{array}{l}\mathrm{NO}_{\mathrm{x}} \\
\mathrm{Ib} / \mathrm{MWh}\end{array}$ \\
\hline Fuel Cell-2 (0.0033) & 157 & 1002 & 473 & 3.02 & 454 & 1036 & 1533 & 3.50 \\
\hline Microturbine-2B (0.541) & 55 & 354 & 389 & 2.48 & 170 & 388 & 1298 & 2.96 \\
\hline Combustion Turbine-2D (1.388) & 75 & 476 & 256 & 1.64 & 223 & 510 & 927 & 2.12 \\
\hline Combustion Turbine-6D (0.278) & 75 & 476 & 430 & 2.75 & 223 & 510 & 1413 & 3.23 \\
\hline Combustion Turbine-6B (0.263) & 86 & 548 & 433 & 2.76 & 255 & 582 & 1419 & 3.24 \\
\hline Natural Gas Engine-2C (2.37) & 121 & 772 & 103 & 0.66 & 353 & 806 & 496 & 1.13 \\
\hline Natural Gas Engine-6C (0.25) & 121 & 772 & 435 & 2.78 & 353 & 806 & 1425 & 3.25 \\
\hline
\end{tabular}

Using the assumed values of $\$ 200$ /ton for $\mathrm{SO}_{2}$ all year and $\$ 1500 /$ ton $\mathrm{NO}_{\mathrm{X}}$ during MaySeptember, $100 \mathrm{MW}$ of baseload microturbines will achieve savings of \$1.15 million and \$0.99 million respectively. (The $\mathrm{SO}_{2}$ price is based on typical prices in the AEO2002, while the $\mathrm{NO}_{\mathrm{X}}$ price corresponds to the lower limit of the Phase II forecast range (Farrell 2002). Actual Phase II prices have generally been lower, but Phase III prices significantly higher.) This is equal to $0.13 \phi / \mathrm{kWh}$ and $0.11 \phi / \mathrm{kWh}$ or a total of $0.24 \phi / \mathrm{kWh}$ of total benefit. Who reaps these benefits depends on the regulations involved in calculation and sale of emission permits (as well as the location of the DER and the displaced central generators), but in the end, all of society has the benefit of cleaner air.

To give an example of the benefit to the owners of the DG if they could claim the reduction in system emissions for themselves, we calculated the improvement in the simple payback for various DG systems. We used the operational parameters and energy (electricity and gas) prices from Table 4 through Table 8. From them it is possible to calculate the annual cost and savings from operating a DG instead of purchasing electricity. It is assumed that the DG owner pays commercial power rates and so DG offsets the rates that PSE\&G or BG\&E would charge, except for the standby charges. Adding the revenue from the credits for reduction in system emissions (the owner also has to pay for the emissions from the DG) lowers the payback period, meaning the plant's net revenue equals its initial cost in a shorter period of time. 
Table 15. Simple payback (years) for a non-CHP DG project with and without revenues from the sale of system emission credits for different technologies, using PSE\&G and BG\&E utility prices.

\begin{tabular}{|c|c|c|c|c|c|c|c|c|}
\hline \multirow{3}{*}{ Technology } & \multicolumn{4}{|c|}{ PSE\&G commercial rates } & \multicolumn{4}{|c|}{ BG\&E commercial rates } \\
\hline & \multicolumn{2}{|c|}{ Peaking } & \multicolumn{2}{|c|}{ Baseload } & \multicolumn{2}{|c|}{ Peaking } & \multicolumn{2}{|c|}{ Baseload } \\
\hline & $\begin{array}{l}\text { W/o E. } \\
\text { Credit }\end{array}$ & $\begin{array}{l}\text { W/ E. } \\
\text { Credit }\end{array}$ & $\begin{array}{l}\text { W/o E. } \\
\text { Credit }\end{array}$ & $\begin{array}{l}\text { W/ E. } \\
\text { Credit }\end{array}$ & $\begin{array}{l}\text { W/o E. } \\
\text { Credit }\end{array}$ & $\begin{array}{l}\text { W/ E. } \\
\text { Credit }\end{array}$ & $\begin{array}{l}\text { W/o E. } \\
\text { Credit }\end{array}$ & $\begin{array}{l}\text { W/ E. } \\
\text { Credit }\end{array}$ \\
\hline Fuel Cell-2 & 40 & 38 & 25 & 22 & 146 & 123 & NA & NA \\
\hline Microturbine-2B & 19 & 17 & NA & 70 & NA & NA & NA & NA \\
\hline Combustion Turbine-2D & 11 & 9.7 & 104 & 24 & NA & NA & NA & NA \\
\hline Combustion Turbine-6D & 15 & 13 & NA & 64 & NA & NA & NA & NA \\
\hline Combustion Turbine-6B & 12 & 11 & 49 & 21 & NA & NA & NA & NA \\
\hline Natural Gas Engine-2C & 6.2 & 5.9 & 5.1 & 4.4 & 44 & 31 & NA & NA \\
\hline Natural Gas Engine-6C & 8.4 & 7.9 & 7.1 & 6.1 & 74 & 48 & NA & NA \\
\hline
\end{tabular}

NA = DG has operating loss so negative payback

Several conclusions can be drawn from Table 15. First, if a DG owner could capture the system benefits of reduced emissions then the payback on the DG system improves roughly $10 \%$. With the electricity and fuel prices from the tables above, and with no CHP, the only technologies with reasonable paybacks ( $<$ ten years) are the natural gas engines under the PSE\&G rate structure.

The use of the DG system waste heat to displace steam generated from boilers will provide even greater savings, especially since the DG will see no increase in emissions over what it produced solely for electric generation. For example, $100 \mathrm{MW}$ produced by multiple Combustion Turbines (6B) during peaking times would produce $313 \mathrm{GWh}$ of electricity and 2,700 GBtu of exhaust heat. Assuming a $62 \%$ CHP heat exchanger efficiency compared to a $72 \%$ efficiency for the nonCHP boiler (Table 8), 2,300 GBtu of natural gas would be saved. This represents $134 \mathrm{kTon}$ of $\mathrm{CO}_{2}$ and, using a $\mathrm{NO}_{\mathrm{x}}$ emission rate of $0.23 \mathrm{lb} / \mathrm{mmBtu}$ for the boiler, 526 tons of $\mathrm{NO}_{\mathrm{x}}$ (Table 13 and Figure 12). When added to the power generation savings already achieved by the DG, the total savings is $219 \mathrm{kTon}$ of $\mathrm{CO}_{2}$ and 958 tons of $\mathrm{NO}_{\mathrm{X}}$. Even greater amounts are saved with the baseload DG scenario. 
Figure 12. Net $\mathrm{CO}_{2}$ and $\mathrm{NO}_{\mathrm{x}}$ emissions from $100 \mathrm{MW}$ of Combustion Turbine-6B with CHP

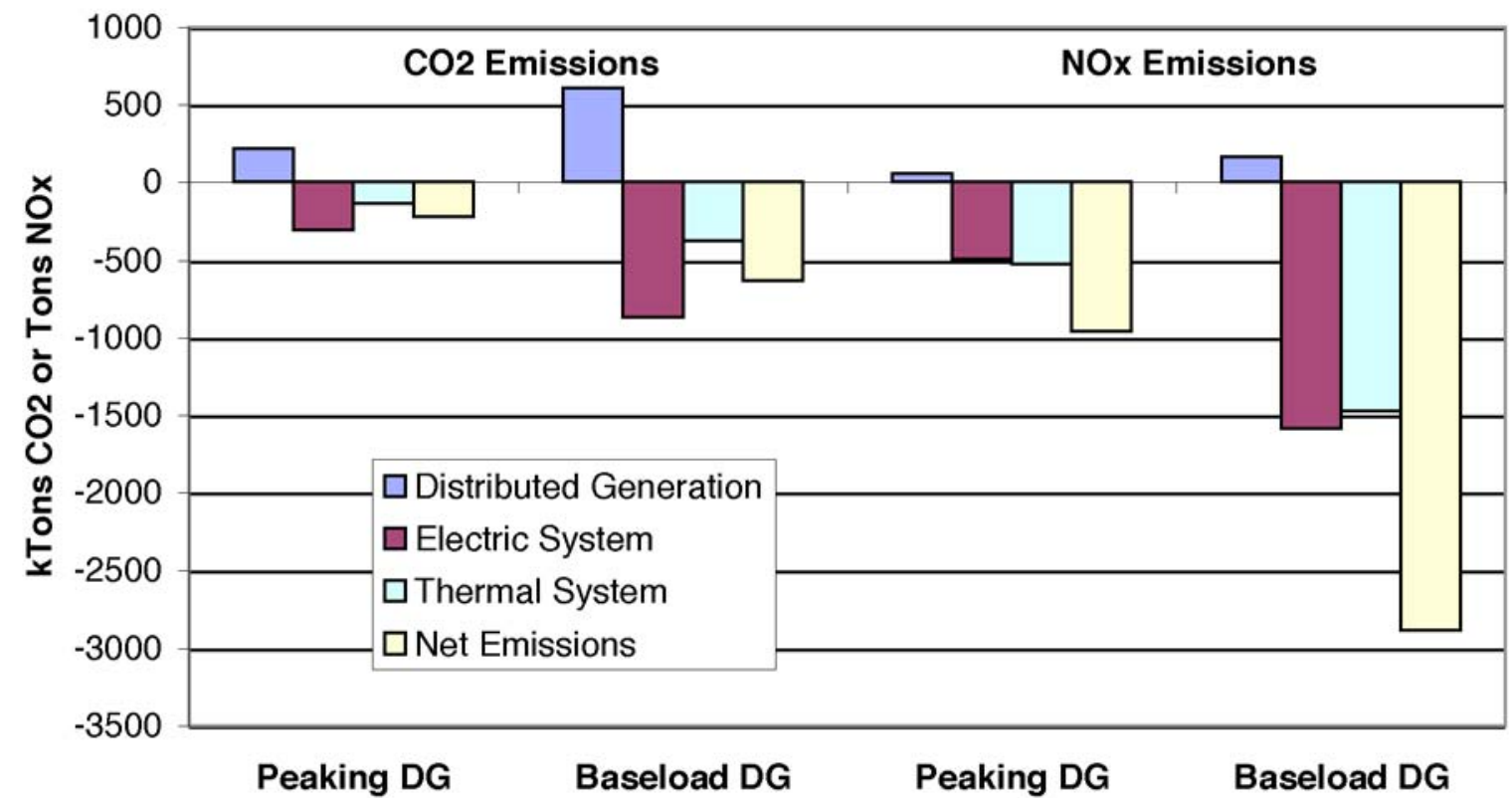

Using the CHP parameters shown in Table 8 for all of the DG technologies listed, the emissions savings are shown in Table 16. Note that without CHP, the fuel cells reduced the $\mathrm{NO}_{\mathrm{x}}$ emissions the most, but their electrical efficiency is highest and their exhaust temperatures are lower so that there is less exhaust heat available for CHP. This reduces the amount of boiler emissions displaced, so that the fuel cells have the least net savings when CHP is used. Also, the relative $\mathrm{CO}_{2}$ emissions savings ranking between natural gas engines and combustion turbines changes when cogeneration is used because the exhaust heat from natural gas engines is available at a lower temperature than that produced by combustion turbines.

Table 16. Net emissions savings from $100 \mathrm{MW}$ of different DG technologies with CHP

\begin{tabular}{|c|c|c|c|c|c|c|c|c|}
\hline \multirow[b]{2}{*}{ Technology, Ib NOx/MWh } & \multicolumn{4}{|c|}{ Peaking DG } & \multicolumn{4}{|c|}{ Baseload DG } \\
\hline & kTon & $\begin{array}{l}\mathrm{CO}_{2} \\
\mathrm{Lb} / \mathrm{MWh}\end{array}$ & Ton & $\begin{array}{l}\mathrm{NO}_{\mathrm{x}} \\
\mathrm{lb} / \mathrm{MWh}\end{array}$ & kTon & $\begin{array}{l}\mathrm{O}_{2} \\
\mathrm{lb} / \mathrm{MWh}\end{array}$ & Ton & $\begin{array}{l}\mathrm{NO}_{\mathrm{x}} \\
\mathrm{lb} / \mathrm{MWh}\end{array}$ \\
\hline Fuel Cell-2, 0.0033 & 215 & 1375 & 703 & 4.49 & 617 & 1409 & 2175 & 4.97 \\
\hline Microturbine-2B, 0.541 & 228 & 1457 & 1068 & 6.82 & 653 & 1491 & 3196 & 7.30 \\
\hline Combustion Turbine-2D, 1.388 & 218 & 1391 & 820 & 5.24 & 624 & 1425 & 2504 & 5.72 \\
\hline Combustion Turbine-6D, 0.278 & 218 & 1391 & 994 & 6.35 & 624 & 1425 & 2990 & 6.83 \\
\hline Combustion Turbine-6B, 0.263 & 219 & 1401 & 958 & 6.12 & 629 & 1435 & 2890 & 6.60 \\
\hline Natural Gas Engine-2C, 2.37 & 208 & 1326 & 444 & 2.83 & 596 & 1360 & 1451 & 3.31 \\
\hline Natural Gas Engine-6C, 0.25 & 208 & 1326 & 776 & 4.95 & 596 & 1360 & 2379 & 5.43 \\
\hline
\end{tabular}

Table 16 provides the insight that if the DG installed includes CHP, emissions become a function not only of the cleanliness of the technology, but the electrical and heat exchanger efficiencies. This is apparent if we plot the system $\mathrm{NO}_{\mathrm{X}}$ savings as a function of the $\mathrm{DG} \mathrm{NO}_{\mathrm{X}}$ emissions rate (Figure 13). While the electric-only system shows a simple linear relationship between the two, 
the plots for the systems with CHP show more variation. Fuel cells, because of their high electrical efficiencies and low exhaust temperature, do not show as large an improvement by adding CHP as do other technologies. With high electrical efficiency there is less exhaust energy to use, compounded by the low temperature, which means that less of the exhaust energy can be captured for end-use. Microturbines, on the other hand, show high savings because of their combination of low emissions and high percentage of exhaust heat utilized (Table 8).

Figure 13. System $\mathrm{NO}_{\mathrm{X}}$ savings as a function of the DG NO $\mathrm{X}_{\mathrm{X}}$ emissions rate

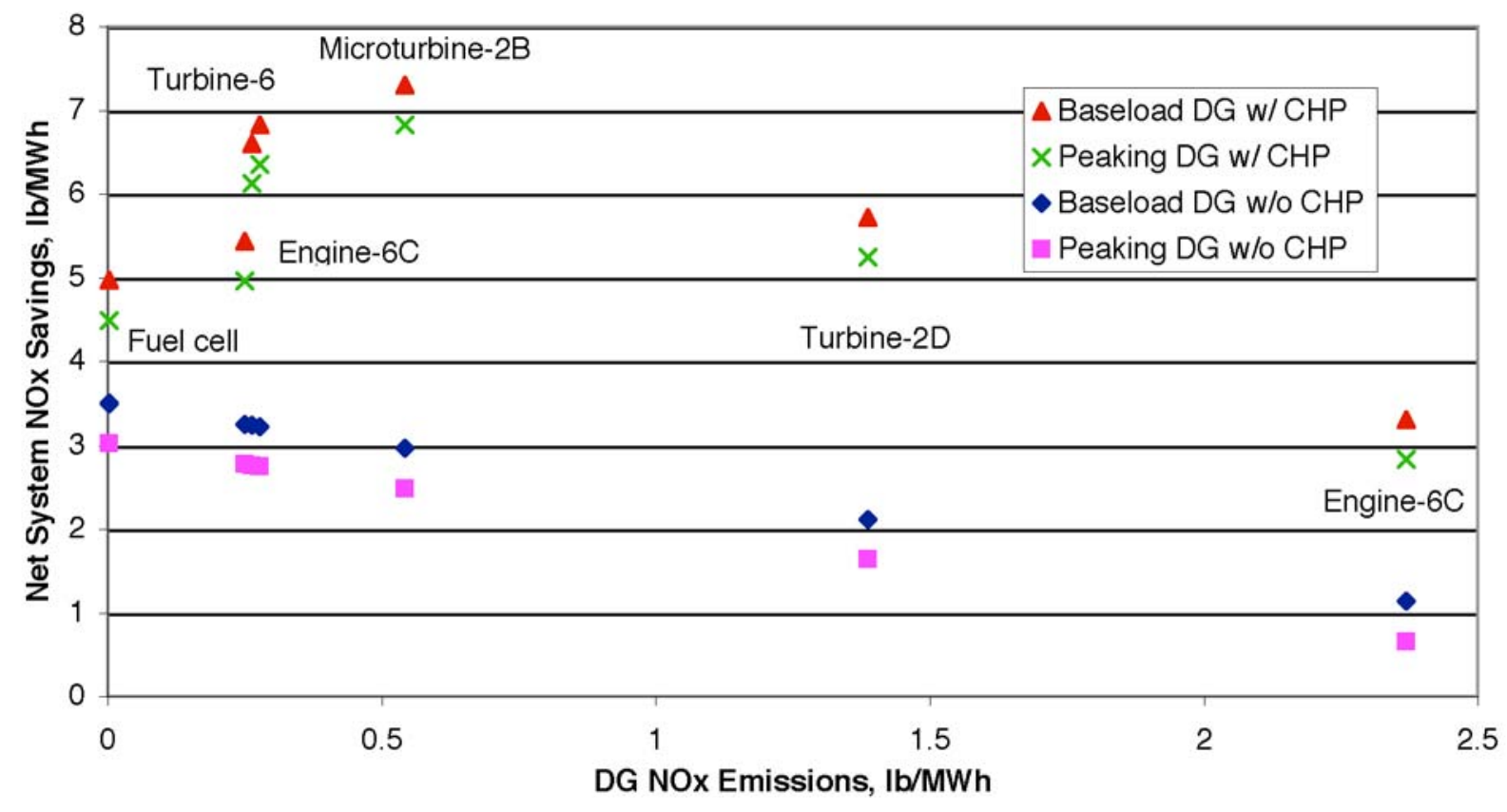

Applying the assumed values of $\$ 200 /$ ton for $\mathrm{SO}_{2}$ all year and $\$ 1500$ /ton $\mathrm{NO}_{\mathrm{X}}$ during MaySeptember, $100 \mathrm{MW}$ of baseload microturbines will achieve savings of \$1.1 million and \$2.18 million respectively. While the $\mathrm{SO}_{2}$ value remains the same as the scenario without CHP, the $\mathrm{NO}_{\mathrm{X}}$ emission savings are higher because of the CHP. The resulting savings is equal to $0.13 \phi / \mathrm{kWh}$ for $\mathrm{SO}_{2}$ and $0.25 \phi / \mathrm{kWh}$ or a total of $0.38 \phi / \mathrm{kWh}$ of total benefit. Applying these savings to all of the technologies shows an improvement in the simple payback (Table 17). 
Table 17. Simple payback (years) for a DER/CHP project with and without revenues from the sale of system emission credits for different technologies, using PSE\&G and BG\&E utility prices.

\begin{tabular}{|l|cc|cc|cc|cc|}
\hline \multirow{2}{*}{ Technology } & \multicolumn{3}{|c|}{ PSE\&G commercial rates } & \multicolumn{3}{c|}{ BG\&E commercial rates } \\
\cline { 2 - 9 } & \multicolumn{2}{|c|}{ Peaking } & \multicolumn{2}{c|}{ Baseload } & \multicolumn{2}{c|}{ Peaking } & \multicolumn{3}{c|}{ Baseload } \\
& W/o E. & W/ E. & W/o E. & W/ E. & W/o E. & W/ E. & W/o E. & W/ E. \\
& Credit & Credit & Credit & Credit & Credit & Credit & Credit & Credit \\
\hline Fuel Cell-2 & 29 & 28 & 15 & 14 & 63 & 58 & 2700 & 180 \\
Microturbine-2B & 5.7 & 5.4 & 3 & 2.8 & 11 & 10 & 29 & 15 \\
Combustion Turbine-2D & 3.9 & 3.7 & 2.1 & 1.9 & 8.4 & 7.4 & NA & 36 \\
Combustion Turbine-6D & 5.1 & 4.8 & 2.8 & 2.6 & 11 & 10 & NA & 210 \\
Combustion Turbine-6B & 4.7 & 4.4 & 2.6 & 2.4 & 10 & 9.2 & NA & 120 \\
Natural Gas Engine-2C & 3.9 & 3.7 & 2.1 & 1.9 & 8.2 & 7.4 & NA & 36 \\
Natural Gas Engine-6C & 5.1 & 4.9 & 2.8 & 2.6 & 11 & 10 & NA & 98 \\
\hline
\end{tabular}

NA = DER has operating loss so negative payback

Even more interesting is the impact of CHP on the payback of the DER, even without the emissions credit. Whereas with electricity generation only, just the natural gas engines showed much profitability, with CHP all but the fuel cells have rapid payback using the PSE\&G rates (compare Table 15 to Table 17). Several of the technologies show a potentially acceptable payback even under the difficult constraints of the BG\&E rates in the Peaking scenario. BG\&E offpeak prices are too low for the Baseload scenario to be viable.

\subsubsection{Generation Reliability Changes}

Reliability for a utility is measured in several ways. Regulators may have a requirement of the maximum number of outages per year per customer and average time to restore power. These measures would include the likelihood of outages from three sectors, generation, transmission, and distribution. Each of these sectors can have different causes and solutions for unreliability.

Loss of Load Probability (LOLP) is a measure often used for generation planning purposes and is stated in terms of days of outage per ten years. The common target is to have a probability of one day of outages per ten years. This is equivalent to $1 / 3650$ or $0.027 \%$ probability. Some customers, such as sensitive industrial processes or Internet service providers, require much higher levels of reliability. Generation reliability can be affected by forced outages from power plants or unexpectedly large demands. The utilities' main solution for generation unreliability is to have in place sufficient reserves to make up the difference from the loss of a major power plant or a specified percentage above the expected peak demand. Reserves are subdivided into different categories based on the speed with which they can provide make-up power, but for our analysis we have combined the spinning and supplemental reserves into a single reserve category when calculating the reserves market price. Typically, a utility needs $3 \%$ over demand for spinning reserve and $4 \%$ for non-spinning reserves. Contingency reserves for typical system operators are also defined by the loss of the single largest generating unit or transmission line. DG would not reduce the contingency reserve on that basis.

Besides the operational reserves modeled here, PJM's Reliability Assurance Agreements with load-serving entities require them to contract for capacity obligations (calculated by the PJM Office of the Interconnection) to meet their expected peak demand plus some capacity benefit 
margin. A capacity credit market has been established to allow buyers to transact with sellers of capacity to meet these obligations. Future expansions of ORCED may allow a more detailed assessment of this market separate from the general reserves market currently modeled.

Optimum reserve requirements can change depending on the size of the units that make up the generation supply. Multiple smaller DG units can provide increased reliability as compared to an equivalent capacity from a single larger unit. If a large unit goes down then an equal amount of capacity is needed to replace it, but with multiple smaller plants it is much less likely that all would be down at the same time. Less backup capacity is needed, and the backup units would run more often. This further improves the economics versus a large amount of backup that is only used when the single large source is down.

With large power markets such as today, the individual capacities of units on the network are small enough compared to total demand that this is not a large issue. However, in the 1970's and 1980's unit size was more important, with large nuclear and coal plants providing a substantial fraction of a utility's capacity and increasing the optimum planning reserve margin. Even today, this factor (smaller individual units) works to drive down the amount of reserve margin required for reliability. DG capacities, if of equivalent availability, can reduce the amount of capacity needed to provide equivalent reliability.

To test the improvement in reliability we ran two additional cases. Instead of simulating the DG by reducing demand, we used the originally reported system demand data and added either a single $100 \mathrm{MW}$ plant or ten $10 \mathrm{MW}$ plants to the collection of power plant units. This increased the system reserve margin from $12.2 \%$ to $12.4 \%$. The change in the LOLP between the two reflects the higher reliability provided by the multiple small plants. Since the $100 \mathrm{MW}$ is such a small fraction of the total demand in the PJM region, little change was noted $(0.07 \%$ improvement as shown in Table 18).

The ORCED model typically runs with a limited number of the power plants having their forced outages treated probabilistically, with the rest modeled through derating their capacity. In these two cases, we treated the added plants probabilistically, along with ten large nuclear plants (as in the base case).

Four other scenarios were established to understand the sensitivity of size of reserve margin and new plant. For all four, the energy needs were increased by 10,000 GWh, which increased the peak demand from 50,948 MW to 53,345 MW. In the first set this increased peak load, combined with the addition of the $100 \mathrm{MW}$ generating capacity, decreased the reserve margin from $12.4 \%$ to 7.3. Running the two cases in this situation showed an even smaller reduction in the loss of load probability by $0.0007 \%$. We next increased the size of the added capacity from $100 \mathrm{MW}$ to $200 \mathrm{MW}, 500 \mathrm{MW}$, and $1000 \mathrm{MW}$ (as either a single plant or ten smaller plants). The change in LOLP was more pronounced, especially with the $1000 \mathrm{MW}$ added capacity. 
Table 18. Loss of Load Probability change when adding multiple smaller versus single larger plant

\begin{tabular}{|c|c|c|c|c|}
\hline & $\begin{array}{c}\text { Reserve } \\
\text { Margin }\end{array}$ & $\begin{array}{c}\text { Single Plant LOLP } \\
\text { (day/10 yr) }\end{array}$ & $\begin{array}{c}\text { Ten Plants LOLP } \\
\text { (day/10 yr) }\end{array}$ & $\begin{array}{c}\% \text { Improvement in } \\
\text { LOLP }\end{array}$ \\
\hline $\begin{array}{l}\text { Added } 100 \text { MW Supply } \\
\text { Added Demand and }\end{array}$ & $12.4 \%$ & 0.057 & 0.057 & $0.07 \%$ \\
\hline 100 MW Supply & $7.3 \%$ & 3.40 & 3.40 & $0.0007 \%$ \\
\hline 200 MW Supply & $7.5 \%$ & 3.08 & 3.08 & $0.0014 \%$ \\
\hline 500 MW Supply & $8.1 \%$ & 2.13 & 2.13 & $0.19 \%$ \\
\hline 1000 MW Supply & $9.0 \%$ & 1.11 & 0.92 & $16.7 \%$ \\
\hline
\end{tabular}

What does this mean to the different stakeholders? Based on the ORCED analysis there is a small but positive value to having capacity added at the unit size of DG as opposed to typical central station size. The main beneficiary may be society. If reserve margins are fixed by PJM at a certain percentage of demand or by the largest single contingency, then society will benefit by increased reliability at the same amount of capacity. This can also lead to lower electricity prices since high cost plants will not be called upon as often. If, however, the ISO chooses to lower the required reserve margins, then utilities may benefit by not having to have as much reserve capacity on hand, through either ownership or the capacity market.

As mentioned above, the total reliability measurement also includes the effect of transmission and distribution reliability. Although these factors have not been evaluated by this regional bulk power analysis, DG may be able to protect the customer from upstream outages in the T\&D system. This is discussed further in section 3 below.

\subsubsection{Reserves Ancillary Services Market}

If there is an open market for small capacity providing ancillary services, as defined in section 2.3, then DG may be able to earn additional revenue during times it is not operating. This will only apply in our Peaking scenario, since in the Baseload scenario the DG is already providing full electrical output to the system. Using the reserves prices shown in Figure 9, and tracing the prices back to the original demand LDC, we can determine the reserves price for any hour of the year. Applying these prices to the $100 \mathrm{MW}$ of DG available for reserves during the off-peak hours, we find that the DG could earn an additional $\$ 1.6 \mathrm{M}$ per year, which translates to $\$ 16 / \mathrm{kW} / \mathrm{yr}$. If the DG only was available as backup and so was available $100 \%$ of the year, it could earn $\$ 2.6 \mathrm{M}$, or $\$ 26 / \mathrm{kW} / \mathrm{yr}$. Since there are no variable operating costs while the DG is in standby and available as a reserve, these funds can be used to offset the fixed cost of the DG. Of course, the equipment will not be available $100 \%$ of the time, so the plant cannot be in the reserve market all of the time it is not operating, and actual payment will be somewhat less depending on the time of the outages.

To examine the influence of different DER technologies we used the operational parameters and energy prices from Table 4 through Table 8 . From them it is possible to calculate the annual cost and savings from operating a DER instead of purchasing electricity and using the thermal energy (via CHP). Adding the revenue from the reserves ancillary market lowers the payback period, meaning the plant's net revenue equals its initial cost in a shorter period of time. More detailed analysis of simple payback periods can be found in section 4.3. 
Table 19. Simple payback (years) for a Peaking-period-only DG project with and without revenues from the reserves ancillary market for different technologies, using different utility prices and a CHP option

\begin{tabular}{|c|c|c|c|c|c|c|c|c|}
\hline \multirow{3}{*}{ Technology } & \multicolumn{4}{|c|}{ PSE\&G commercial rates } & \multicolumn{4}{|c|}{ BG\&E commercial rates } \\
\hline & \multicolumn{2}{|c|}{ W/o CHP } & \multicolumn{2}{|c|}{ With CHP } & \multicolumn{2}{|c|}{ W/o CHP } & \multicolumn{2}{|c|}{ With CHP } \\
\hline & $\begin{array}{c}\text { W/o } \\
\text { Ancil }\end{array}$ & W/ Ancil & $\begin{array}{c}\text { W/o } \\
\text { Ancil }\end{array}$ & W/ Ancil & $\begin{array}{c}\text { W/o } \\
\text { Ancil }\end{array}$ & W/ Ancil & $\begin{array}{c}\text { W/o } \\
\text { Ancil }\end{array}$ & W/ Ancil \\
\hline Fuel Cell-2 & 40 & 35 & 29 & 27 & 146 & 99 & 63 & 53 \\
\hline Microturbine-2B & 19 & 11 & 5.7 & 4.7 & NA & NA & 11 & 9.6 \\
\hline Combustion Turbine-2D & 11 & 8.5 & 3.9 & 3.6 & NA & NA & 8.4 & 7 \\
\hline Combustion Turbine-6D & 15 & 11.6 & 5.1 & 4.6 & NA & NA & 11 & 9.4 \\
\hline Combustion Turbine-6B & 12 & 9.6 & 4.7 & 4.3 & NA & NA & 10.3 & 8.5 \\
\hline Natural Gas Engine-2C & 6.2 & 5.4 & 3.9 & 3.5 & 44 & 21 & 8.2 & 6.9 \\
\hline Natural Gas Engine-6C & 8.4 & 7.3 & 5.1 & 4.7 & 74 & 31 & 11 & 9.2 \\
\hline
\end{tabular}

$\mathrm{NA}=\mathrm{DER}$ has operating loss so negative payback

Several conclusions can be drawn from the results summarized in Table 19. The ancillary services revenue can reduce the payback period by over $10 \%$. For projects close to the threshold for viability (such as the CHP projects using PSE\&G rates) the additional revenue can be sufficient to make the project worthwhile. Second, the addition of CHP gives a strong benefit to DER, lowering the payback period to competitive levels, or even changing the DER from unprofitable to profitable. Third, the BG\&E electricity rates are low enough that it is difficult for even CHP using the peak profile to be economic at all, but the PSE\&G rates are high enough that some combinations of technology and operating profile can give low payback periods.

Separate from the reserves market, PJM also conducts a capacity market (PJM 2003). PJM requires each load-serving entity to contract sufficient capacity to meet their expected peak demand plus the amount of reserves necessary to have a loss of load probability less than one day in ten years.

\subsubsection{Costs to Utilities}

Although independent owners may see a benefit from developing DG (based on comparing the costs of DG versus their electricity prices) and society may see a benefit from DG (based on lower emissions, greater reliability, or lower overall costs), the utilities may or may not see a benefit. The lost revenue from lower sales will likely be higher than the reduction in cost from power purchases on the wholesale market. (This may be obviated if the utility owns the DG itself.)

In our example, the average wholesale purchase price of power (using the PJM prices) displaced by the DG was $4.43 \notin / \mathrm{kWh}$ in the Peaking scenario and $2.83 \notin / \mathrm{kWh}$ in the Baseload scenario (Table 12). This translates into avoided power purchase costs of $\$ 14$ million and $\$ 25$ million respectively. However, using the commercial power rates in Table 4 through Table 6, PSE\&G would lose revenue of $8.93 \phi / \mathrm{kWh}$ and $7.01 \phi / \mathrm{kWh}$ for the two scenarios giving net losses of $4.50 \phi / \mathrm{kWh}$ and $4.18 \phi / \mathrm{kWh}$ (Table 20). Because of its different rate structure, BG\&E would lose only $1.56 \phi / \mathrm{kWh}$ and $0.46 \notin / \mathrm{kWh}$ in net revenues. However, as shown in Table 19 above, the lower loss for this utility corresponded to lower savings for the DG owner and consequent longer payback. 
Table 20. Utility net revenue changes with 100 MW of DG

\begin{tabular}{|lccc|}
\hline & $\begin{array}{c}\text { Avoided Power Purchase, } \\
\phi / \mathrm{kWh}\end{array}$ & $\begin{array}{c}\text { Lost Revenue from Power } \\
\text { Sale, } \phi / \mathrm{kWh}\end{array}$ & $\begin{array}{c}\text { Net Gain (Loss), } \\
\phi / \mathrm{kWh}\end{array}$ \\
\hline \hline PSE\&G & & & \\
Peaking DG & 4.43 & 8.93 & $(4.50)$ \\
Baseload DG & 2.83 & 7.01 & $(4.18)$ \\
\hline BG\&E & & & \\
Peaking DG & 4.43 & 5.99 & $(1.56)$ \\
Baseload DG & 2.83 & 3.29 & $(0.46)$ \\
\hline
\end{tabular}

The utilities may also have lower operating costs in other categories such as T\&D or billing, but most of these other costs do not vary much by the amount of electricity sold. In the long run, the utilities will save expenses through postponement of capital expenditures for T\&D upgrades (see section 3 below). They may also save through emissions reductions, although the cost of permits was included in the power prices above (at $\$ 200 /$ ton $\mathrm{SO}_{2}$ annually and $\$ 1500 /$ ton $\mathrm{NO}_{\mathrm{X}}$ during the peak season.) The reduction in emissions from DG may lower the price of the remaining emissions, but the influence is not likely to be large.

\subsubsection{Sensitivity to Change in Fuel Cost}

When the displaced power mechanism is used to evaluate the value of DG, the result is dependent on the operation of the rest of the system and is therefore beyond the control of the DG project. The results can be sensitive to factors such as the price of fuels for the grid's power plants or other external factors. Changes in relative prices can alter the order of plants on the margin and change the marginal emissions and prices. For example, our cases used fuel prices based on 1999 values (Table 3). Using prices reflective of estimates for 2005 from the Annual Energy Outlook 2002, which plants are on the margin when shifts around, as do the resulting marginal emissions and prices (Table 21).

Table 21. Displaced system power parameters with 1999 and 2005 fuel prices

\begin{tabular}{|c|c|c|c|c|}
\hline & \multicolumn{2}{|c|}{ Peaking DG } & \multicolumn{2}{|c|}{ Baseload DG } \\
\hline & 1999 & 2005 & 1999 & 2005 \\
\hline Displaced Energy, GWh & 313 & 313 & 876 & 876 \\
\hline Average Oil Price, $\$ / m m B t u$ & 2.18 & 3.78 & 2.18 & 3.78 \\
\hline Average Gas Price, $\$ / \mathrm{mmBtu}$ & 2.98 & 3.34 & 2.98 & 3.34 \\
\hline Average Coal Price, $\$ / \mathrm{mmBtu}$ & 1.46 & 1.32 & 1.46 & 1.32 \\
\hline $\begin{array}{c}\text { Displaced Source } \\
\text { Oil ST }\end{array}$ & $36 \%$ & $37 \%$ & $31 \%$ & $22 \%$ \\
\hline Oil CT & $7 \%$ & $4 \%$ & $4 \%$ & $2 \%$ \\
\hline Gas ST & $2 \%$ & $2 \%$ & $1 \%$ & $2 \%$ \\
\hline Gas CT & $10 \%$ & $18 \%$ & $5 \%$ & $10 \%$ \\
\hline Gas CC & $11 \%$ & $12 \%$ & $8 \%$ & $10 \%$ \\
\hline Coal & $35 \%$ & $26 \%$ & $52 \%$ & $54 \%$ \\
\hline Avg Displaced Efficiency & $31 \%$ & $31 \%$ & $32 \%$ & $32 \%$ \\
\hline $\mathrm{NO}_{\mathrm{x}}, \mathrm{Ib} / \mathrm{MWh}$ & 3.03 & 2.65 & 3.59 & 3.48 \\
\hline $\mathrm{SO}_{2}, \mathrm{Ib} / \mathrm{MWh}$ & 9.67 & 8.21 & 13.1 & 12.7 \\
\hline $\mathrm{CO}_{2}, \mathrm{Ib} / \mathrm{MWh}$ & 1,938 & 1823 & 1,972 & 1917 \\
\hline Avg. Marginal Cost, $\phi / k W h$ & 2.99 & 3.84 & 2.62 & 3.10 \\
\hline
\end{tabular}


Several interesting changes occur with the change in fuel prices. In the Peaking scenario, the major change is the reduction in coal and increase in gas as the marginal production, while in the Baseload scenario oil decreases and gas increases as the marginal fuel. Coal prices are lower so coal plants provide more of the baseload production, moving gas plants onto the margin. At the same time, oil prices rise much more than gas so that oil is reserved more for peaking applications than in the 1999 price scenario.

This analysis focused on the system changes associated with a change in fuel prices. However, the DER system economics will also be affected by changing fuel prices. CHP systems will be less sensitive to such price changes because they serve a thermal load that would have been served by the fuel whether or not the DER system were installed. 


\section{Long-Term Aggregate Avoided T\&D Costs}

This chapter considers the value of DG in displacing the need for upstream T\&D capacity. As mentioned earlier, avoided T\&D costs for DG do not necessarily occur at the same time that DG capacity is added because often the T\&D resources are already in place. However, in the longrun, T\&D resources must be maintained, replaced, and usually augmented. Therefore, in the long-term view, DG should contribute to a reduction in T\&D expenses.

This analysis assumes that the DG capacity is connected to a local distribution system and serves a load(s) on that system, and therefore has the potential to reduce the demand on the upstream distribution system by an amount equivalent to the total DG capacity. Given this assumption, the operation of DG will tend to displace T\&D service provided by local utilities. This should reduce the need for transmission lines and associated equipment, power substations, and the distribution conductors, conduit, and supporting structures that transfer power at distribution voltages from the substation to homes and businesses. "Line transformers" that reduce distribution voltages to the end-use voltages would only be displaced if the DG-supplied load did not require backup power.

The key issue in estimating the avoided T\&D capacity costs is to determine the effect DG has on the need for future T\&D equipment. The local utility's T\&D resources are not needed to serve a load while the DG is operating, but must still provide backup capacity. Such uncertainty, related to DG's availability, is a key factor in determining the difference in distribution capacity requirements with and without DG.

\subsection{DG Capacity Value, Site-Specific Approach}

Utilities typically assess the T\&D potential of DG by focusing on opportunities where planned expansions or upgrades of the distribution system can be avoided or deferred. The avoided T\&D cost of DG is typically evaluated case-by-case, based on the specific conditions, and considering plans for upgrading an existing distribution system. The required investment in distribution equipment over some future period without DG is compared to the required investment with DG (Hoff 1996). Then the value of DG is determined based on its ability to defer the cost of expanding or upgrading the distribution system. From this perspective, DG may have a net value because investments in traditional distribution and/or transmission equipment often include large increments resulting in a period of excess capacity until demand increases to utilize that capacity. In essence, smaller increments of DG can reduce traditional distribution capacity costs by more precisely matching capacity expansion to growth in demand.

\subsection{DG Capacity Value, Integrated System Approach}

This analysis looks at DG's potential to avoid distribution capacity costs from a different perspective - that of a long-run equilibrium in which DG is fully planned and coordinated with distribution capacity. The premise is that in the long run, all distribution capacity must be replaced and/or upgraded. Therefore, any increase in DG capacity has the potential to avoid distribution capacity costs. This assumes the distribution/utility system planning process has the potential to develop mechanisms that take into consideration non-utility planned DG capacity. This departure from the typical approach is realistic because of the expectation that DG will provide a significant fraction of new capacity on the system. As such, it will move beyond the 
current niche market role. Furthermore, significant congestion on the T\&D system gives T\&D system planners new and increasing incentives to optimize their systems to account for the effect of DG during capacity-critical periods. In other words, the T\&D system has the opportunity to adapt to take full advantage of the DG units on the system. Taking this perspective provides a generalized framework in which to estimate the value of DG as opposed to its situation-specific value.

It should be emphasized that (even as a bounding case) the approach taken here will shed little light on the value of specific DG installations, especially in the near-term time frame. For instance, in cases where there is significant excess distribution capacity, specific DG installations may have little or no value whatsoever in deferring distribution capacity. In other cases, where demand on parts of the distribution system can only be relieved by increasing the capacity at a high cost--and projected future demand growth is slow--DG that relieved the capacity constraint would tend to have a much higher value than for the "optimized planning case" that is examined below.

This integrated system analysis is composed of several steps. First, the aggregate effect of DG on the system is estimated to provide a basis for determining the transmission and distribution capacity that DG could avoid. Then, the marginal cost of T\&D capacity is determined based on cost data from FERC Form-1 accounts. Finally, information about the potential market penetration and technical characteristics of the DG technology are used to characterize potential future mixes of DG and distribution capacity. Relating the marginal cost and potentially avoided distribution capacity with DG's market potential gives an estimate of potentially avoided T\&D capacity costs.

\subsubsection{Effect of Diversified Coincident Operation}

DG affects the distribution system it is connected to by effectively reducing load when it operates. The distribution system is not required to serve the load as long as DG operates. However, when DG does not operate, or operates at a reduced level, the system's distribution capacity is required to "make-up the deficit" by delivering power from some other source. Because the required distribution capacity is determined by the peak demand, the relevant capacity requirements are also determined based on the peak demand. If all the DG was controlled by the utility responsible for the distribution system, then its effect on distribution capacity requirements could be modeled similar to that of generating units that can be dispatched to meet a utility system's peak demand. However, when DG is operated by one of the utility's customers, the utility does not control the DG units the way it would its own generating units. Even so, the utility can make assumptions about when the DG units operate relative to the capacity critical periods.

For instance, utilities routinely make probability assumptions in sizing distribution transformers that serve utility customers. The transformer size is selected to accommodate the peak simultaneous demand (coincident peak) based on a probability estimate of the coincident maximum of the individual loads on the transformer. Coincidence factors, that adjust the maximum individual loads to a coincident load, are calculated based on statistics characterized by the number of customers and the types of appliances that are typically utilized during the peak periods. Because appliances will not all be in operation at the same time, credit can be taken for "diversification" of the individual loads. As a distribution transformer serves more customers, 
the transformer capacity required per appliance will tend to approach a level characteristic for that type of appliance. An example is an electric range that typically requires a maximum of 4 $\mathrm{kW}$ of power and an average of $1 \mathrm{~kW}$ during the peak period. For one customer on a transformer, the diversified demand would be $4 \mathrm{~kW}$, i.e. there would be no credit for diversification in calculating the peak transformer capacity required. However, as more customers with electric ranges are added to the transformer the diversified demand per customer approaches $1 \mathrm{~kW}$ (i.e. the average) at the coincident peak.

The same principle of diversification can be applied to DG. As more DG units operate on a given component of distribution capacity, the diversified effect will tend to approach the average operating capacity of the DG units for that period. This suggests that for T\&D equipment that accommodates many DG units of similar size, the reduced need for capacity would approach the average operating capacity of DG during the peak demand period. Furthermore, because they affect relatively large increments of load, DG units can be provided with incentives for operating during capacity-critical periods. If these incentives induce the customers to operate their DG systems at their maximum output during periods of peak demand, the effect would be to displace the need for distribution capacity equivalent to DG's maximum output capacity, adjusted for their characteristic forced outage rates. It follows that, if the loads and DG units on the distribution system are known, the system capacity can be adjusted to account for the reduction in loads resulting from DG's operation during capacity-critical periods. The following provides a method for calculating the equivalence between DG units and distribution capacity for a given level of reliability.

\subsubsection{Effect on Upstream Distribution Capacity Requirements}

If DG is operated to minimize distribution capacity required during periods of peak demand and if each DG unit is the same size and all units have the same forced outage rate - then the following equation can be solved to determine the effect of DG capacity in reducing demand on distribution equipment that is upstream from the DG capacity.

Where:

$$
D G_{F O}^{(N-X)} \leq 1-R C
$$
$\mathrm{RC}$
is the desired Reliability Criteria for the DG units as a group;
$1-\mathrm{RC}$
$\mathrm{DG}_{\mathrm{FO}}$ is the desired maximum outage rate for the DG units as a group. is the Distributed Generation Individual Unit Forced Outage Rate, which
$\mathrm{N}$ is assumed to be the same for each DG unit; is the number of DG units downstream from the distribution equipment that is being evaluated for avoided capacity (such as a distribution substation);
$\mathrm{X} \quad$ is the maximum number of DG units that can be counted on at the desired reliability criteria (RC). The sum of the capacity for the $\mathrm{X}$ units defines the capacity credit for DG at the desired Reliability Criteria;

This equation can be solved as:

$$
X=\max (\text { integer }) \leq N-\frac{\ln (1-R C)}{\ln \left(D G_{F O}\right)}
$$


For the given assumptions, this equation (see Table 22 and Figure 14) indicates DG's ability to offset upstream capacity requirements by calculating the number of DG systems that can be counted upon to operate coincidently at the selected reliability criteria. For example, if the reliability criteria is $99.99 \%$ (reflecting an outage probability less than $0.1 \mathrm{~h} /$ year), there are eight DG units on the same feeder, and each DG unit has a forced outage rate of $5 \%$, then the distribution utility can count on at least four of the units operating at the same time. If each of these DG units were rated at $400 \mathrm{~kW}$, the distribution utility would be able to reduce their planned feeder capacity by $1,600 \mathrm{~kW}$. The equation also indicates that either increasing the number of DG units and/or decreasing the individual unit outage probability decreases the required capacity of upstream distribution equipment by increasing the total number of coincidentally-available DG units.

These equations and the example shown in Table 22 are for the simplified case where all DG units are the same size and have the same unit forced outage rates. However, for more complicated cases it would be straightforward to estimate DG's avoided capacity effects using other statistical techniques, such as Monte Carlo simulations.

Table 22 Maximum number of DG units available, based on $99.99 \%$ reliability (or $\mathrm{RC}=.9999$ ), for alternative DG outage rates and system diversity

\begin{tabular}{|c|ccc|}
\hline $\begin{array}{c}\text { System Diversity } \\
\text { (Total DG Units on } \\
\text { the System = N) }\end{array}$ & \multicolumn{3}{|c|}{$\begin{array}{c}\text { Maximum Number of DG Units } \\
\text { Available = X }\end{array}$} \\
\cline { 2 - 4 } & \multicolumn{3}{|c|}{ Outage Probability } \\
\cline { 2 - 4 } & $\mathbf{2} \% \mathbf{D G}_{\text {Fo) }}$ ) & $\mathbf{5 \%}$ & $\mathbf{1 5 \%}$ \\
\hline 4 & 1 & 0 & 0 \\
5 & 2 & 1 & 0 \\
6 & 3 & 2 & 1 \\
7 & 4 & 3 & 2 \\
8 & 5 & 4 & 3 \\
9 & 6 & 5 & 4 \\
10 & 7 & 6 & 5 \\
11 & 8 & 7 & 6 \\
12 & 9 & 8 & 7 \\
13 & 10 & 9 & 8 \\
14 & 11 & 10 & 9 \\
15 & 12 & 11 & 10 \\
16 & 13 & 12 & 11 \\
17 & 14 & 13 & 12 \\
18 & 15 & 14 & 13 \\
19 & 16 & 15 & 14 \\
20 & 17 & 16 & 15 \\
\hline
\end{tabular}


Figure 14. DG unit credit based on outage rates and $99.99 \%$ reliability criteria

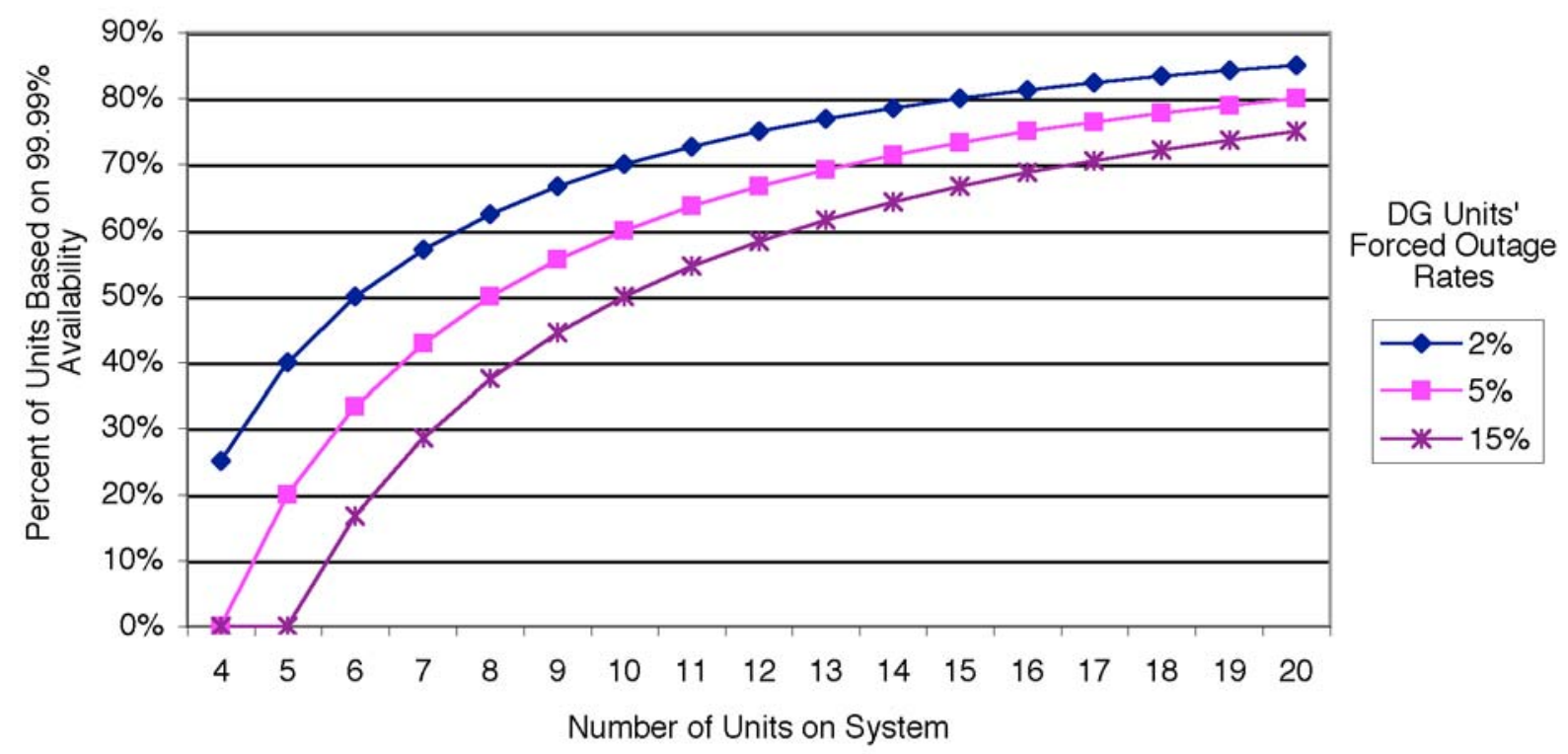

\subsection{The Marginal Cost of T\&D Capacity}

Table 23 provides the breakout value of distribution equipment for major utilities in 1998 as reported in FERC Form 1. Accounts 360 through 368 include distribution equipment potentially affected by DG. This includes $82 \%$ of the total value of distribution equipment book value in 1998. The End of Year Balances (EOYB) for total distribution plant "in service", measures an embedded value of distribution capital that is part of the electric utility's rate base. Therefore, the EOYB divided by the total MVA for Distribution Line Transformers provides an average value of distribution capacity that is eventually incorporated into utilities' rate bases and passed through to all customers through electric rates. In 1989 the average EOYB per MVA for 105 major utilities (does not include transmission) was $\$ 104,198 / \mathrm{MVA}$ (\$104/kVA), increasing to $\$ 137,576 / \mathrm{MVA}$ in 1998 (see Table 23). This increase reflects the fact that, on average, new distribution capacity costs more than the installed base. However, because the purchases each year are only about $5 \%$ of the installed base, the average will change only slowly. Table 23 also presents average equipment costs for 11 PJM utilities. The PJM average costs were significantly higher than the national averages.

Table 23 also presents both national and PJM marginal equipment costs. An approximation of the marginal cost for new equipment was determined by taking the difference in the account EOYB's for 1998 and 1989 divided by the difference in the distribution capacity for the same period. (The marginal rates tend to vary greatly from year to year, so a ten-year time span was used to get a reasonable average value.) The distribution capacity was taken to equal the Distribution Line Transformer capacity. Over this period, the marginal cost of distribution capacity was \$290,203/MVA nationally and \$374,737/MVA for the 11 PJM utilities. In other words, the average marginal cost of distribution capacity over this period was more than double the average embedded cost. The marginal cost for transmission for the same period was $\$ 80,650 /$ MVA for the 105 nationwide utilities and \$64,876/MVA for the 11 PJM utilities. 
Table 23. End of year balance of distribution equipment for 105 nationwide utilities and 11 PJM utilities

\begin{tabular}{|lcrrr|}
\hline & \multicolumn{2}{c}{ Marginal Cost (\$MVA) } & \multicolumn{2}{c|}{ Average Cost (\$/MVA) } \\
& National & PJM & National & PJM \\
FERC Form1 Account & $\mathbf{1 9 8 9}$ to 1998 & 1989 to 1998 & \multicolumn{1}{c|}{$\mathbf{1 9 9 8}$} & $\mathbf{1 9 9 8}$ \\
\hline Dist Land (360) & 2,639 & 5,653 & 1,501 & 2,978 \\
Dist Structures (361) & 2,481 & 5,538 & 1,219 & 3,408 \\
Dist Station Equip (362) & 32,869 & 57,248 & 16,925 & 25,820 \\
Dist Battery Storage (363) & 2 & 0 & 0 & 0 \\
Dist Poles \& Towers (364) & 50,390 & 50,746 & 22,403 & 24,457 \\
Dist Overhead Conduct (365) & 52,059 & 63,363 & 22,246 & 28,366 \\
Dist Undgr Conduit (366) & 13,815 & 23,739 & 6,428 & 12,376 \\
Dist Undgr Conduct (367) & 44,226 & 65,121 & 18,043 & 26,885 \\
Dist Transformers (368) & 40,787 & 39,757 & 23,656 & 24,715 \\
Dist Services (369) & 26,553 & 34,494 & 11,888 & 16,433 \\
Dist Meters (370) & 13,625 & 14,045 & 7,655 & 8,989 \\
Dist Installations (371) & 2,854 & 4,858 & 1,133 & 1,327 \\
Dist Leased Property (372) & -131 & 1 & 42 & 6 \\
Dist Street Lights (373) & 8,034 & 10,175 & 4,438 & 4,610 \\
\hline Dist Total & 290,203 & 374,737 & 137,576 & 180,369 \\
\hline Trans Total & 80,650 & 64,876 & 52,229 & 48,681 \\
\hline Total Dist and Transmission & 370,853 & 439,613 & 189,805 & 229,050 \\
\hline
\end{tabular}

Source: The data is from 105 utilities selected from the intersection of utilities for these accounts in both 1989 and 1998 included in the POWERdat database (Resource Data International, Inc.). This data was originally from data collected in FERC Form 1.

\subsection{The Value of T\&D Investments Avoided by DG}

Only a portion of the distribution and transmission equipment will experience the reduction in load resulting from the DG operation. Figure 15 provides a simplified diagram of a distribution system with 10 DG units downstream from a power substation. It is clear that all DG units downstream would affect the load on the substation. The DG units' location relative to the upstream distribution feeder and sub-feeder equipment is unknown. A conservative assumption for these line capacity savings (accounts 364 thru 367) is employed in the following estimate.

Table 24 combines the marginal costs derived from the FERC Form 1 data (columns 1 and 2) with the DG unit availability data in Table 22 to develop an avoided capacity value of DG. The values shown in the third column of Table 24 were calculated using the following assumptions: (1) DG capacity planned in conjunction with new substations and associated capacity; (2) total per unit substation capacity of 30 MVA; (3) $20 \%$ of substation load met by $\mathrm{DG}^{1}$; (4) power factor of 0.9 ; (5) $10 \mathrm{DG}$ units per substation with per unit capacity of $540 \mathrm{~kW}$ (indicating from

\footnotetext{
${ }^{1}$ The basis for a $20 \%$ assumption is DOE's Distributed Energy Resources Program's expectation that by 2010 DG will be $20 \%$ of all new generation. See "Market Potential" in the Distributed Energy Resources Program brochure: http://www.nrel.gov/docs/fy02osti/31251.pdf
} 
Table 22 that at a $5 \%$ forced outage rate 6 out of 10 units or $60 \%$ of DG capacity can be counted); (6) on average the overhead and underground distribution lines (distribution poles and towers, conductors and conduit--FERC accounts 364 through 367) are upstream of 5 DG units (see Figure 15 for five units and a FOR of 5\%) which makes 1 DG unit out of 5 or $20 \%$ capacity that can be counted on to avoid this type of distribution capacity (see Table 22); (7) on average transmission resources are upstream from two substations (16 out of 20 or $80 \%$ of DG units can be counted on); and (8) distribution FERC Form 1 accounts 368 through 373 including distribution line transformers were assumed to have no costs that could be avoided by DG. The values used here have been estimated based on reasonable assumptions, but their usefulness would be improved with empirical investigation.

\section{Figure 15. Diagram of distribution capacity upstream from DG}

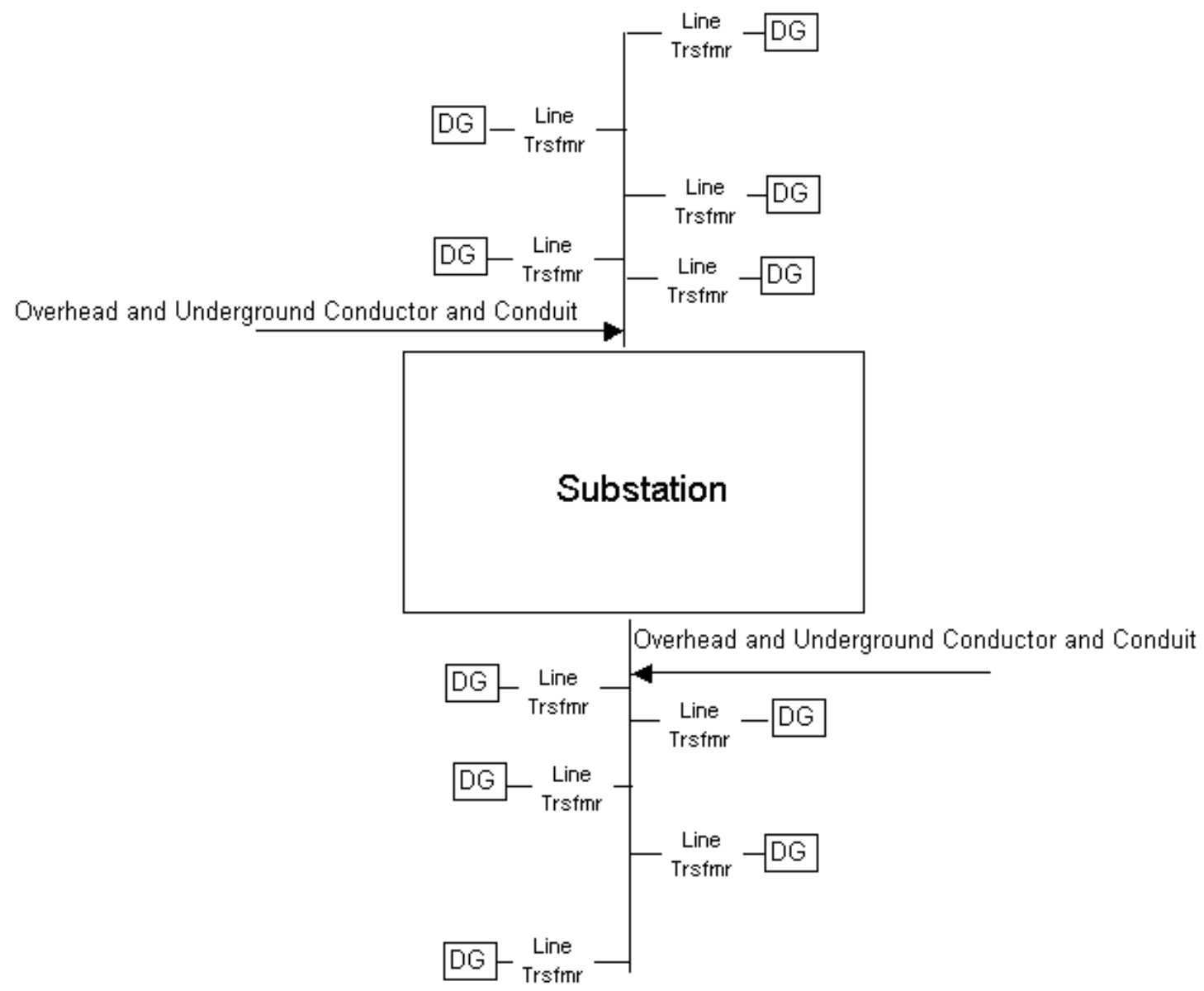

The total value of DG based on the marginal cost for 105 nationwide utilities would then be about $\$ 120 / \mathrm{kVA}$ of installed distribution capacity displaced. Assuming a power factor of 0.9 , the equivalent DG capacity would be about $1.1 \mathrm{kVA}$ of distribution capacity per $\mathrm{kW}$ of installed DG capacity. Therefore, the avoided cost would be about $\$ 132 / \mathrm{kW}$ of DG capacity $(1.1 * \$ 120)$. The similar calculation for the 11 PJM utilities would be $\$ 147 / \mathrm{kW}$ of DG capacity. 
Table 24. Approach for calculating the value of transmission and distribution equipment costs avoided by distributed generation

\begin{tabular}{|c|c|c|c|c|c|c|}
\hline \multirow[b]{2}{*}{ Equipment } & \multicolumn{2}{|c|}{$\begin{array}{c}1989 \text { to } 1998 \\
\text { Marginal Cost } \\
(\$)\end{array}$} & \multirow{2}{*}{$\begin{array}{l}\text { Down- } \\
\text { stream } \\
\text { DG Units } \\
\text { (Number) }\end{array}$} & \multirow[b]{2}{*}{$\begin{array}{c}\text { Capacity } \\
\text { Credit }\end{array}$} & \multicolumn{2}{|c|}{$\begin{array}{c}\text { Avoided Capacity Value } \\
\text { of DG based on Margina } \\
\text { Costs }(\$)\end{array}$} \\
\hline & $\begin{array}{c}\text { Nationwide (105 } \\
\text { Utilities) }\end{array}$ & $\begin{array}{l}11 \text { PJM } \\
\text { Utilities }\end{array}$ & & & $\begin{array}{c}\text { Nationwide } \\
\text { (105 Utilities) }\end{array}$ & $\begin{array}{l}11 \text { PJM } \\
\text { Utilities } \\
\end{array}$ \\
\hline Dist Land & 2,639 & 5,653 & 10 & $60 \%$ & 1,583 & 3,392 \\
\hline Dist Structures & 2,481 & 5,538 & 10 & $60 \%$ & 1,488 & 3,323 \\
\hline Dist Station Equip & 32,869 & 57,248 & 10 & $60 \%$ & 19,722 & 34,349 \\
\hline Dist Battery Storage & 2 & 0 & 10 & $60 \%$ & 1 & 0 \\
\hline Dist Poles \& Towers & 50,390 & 50,746 & 5 & $20 \%$ & 10,078 & 10,149 \\
\hline Dist Overhead Conduct & 52,059 & 63,363 & 5 & $20 \%$ & 10,412 & 12,673 \\
\hline Dist Undgr Conduit & 13,815 & 23,739 & 5 & $20 \%$ & 2,763 & 4,748 \\
\hline Dist Undgr Conduct & 44,226 & 65,121 & 5 & $20 \%$ & 8,845 & 13,024 \\
\hline Dist Transformers & 40,787 & 39,757 & 0 & $0 \%$ & 0 & 0 \\
\hline Dist Services & 26,553 & 34,494 & 0 & $0 \%$ & 0 & 0 \\
\hline Dist Meters & 13,625 & 14,045 & 0 & $0 \%$ & 0 & 0 \\
\hline Dist Installations & 2,854 & 4,858 & 0 & $0 \%$ & 0 & 0 \\
\hline Dist Leased Property & -131 & 1 & 0 & $0 \%$ & 0 & 0 \\
\hline Dist Street Lights & 8,034 & 10,175 & 0 & $0 \%$ & 0 & 0 \\
\hline Trans Total & 80,650 & 64,876 & 20 & $80 \%$ & 64,520 & 51,901 \\
\hline Total & 370,853 & 439,613 & & & 119,412 & 133,557 \\
\hline
\end{tabular}

This analysis considered DG's potential to avoid distribution capacity costs from the perspective of a long-run equilibrium in which DG is planned and coordinated with a distribution system. This provides an alternative perspective to the typical valuation of DG's value based on specific situations where DG may or may not defer investments in distribution capacity. The analysis provides some insights about the capacity value of DG installations that have been coordinated with the distribution system.

A key point is that DG has capacity value for a distribution system to the extent that it reduces the need for upstream capacity. Therefore, it makes sense to first calculate the potential value of DG as if it could be centrally dispatched. Then this potential value can be systematically exploited. Among other things, the distribution system can be designed or adapted to technically accommodate DG. Finally, market designs, such as incentives for operating DG during capacity critical periods, can provide the basis for avoiding distribution capacity costs while meeting system reliability goals even when DG is not owned and/or controlled by the distribution utility. 


\section{DG Owner Economics in the PJM Region}

Many evaluation tools are available to determine the owner's costs and benefits for a specific DG installation. In general, the net economic effect is a function of the DG system's capital, installation, and operating costs, the DG system's efficiency, and the prices of alternative sources for the service(s) provided by the DG system. The calculations are typically complicated by the technical and economic relationships between the DG system and the utility grid. This relationship has important financial elements, including the costs and time needed to meet interconnection requirements, stand-by charges, exit fees, and other rate schedule factors. Other installation costs are incurred meeting environmental regulations; some of these costs actually go toward equipment that reduces emissions, but a substantial portion of these costs goes toward obtaining necessary permits. In addition to these utility and environmental requirements, there are also costs associated with meeting local zoning and construction permit regulations.

Many of these costs will be site specific, and are therefore not considered in the following general analysis of owner benefits for the PJM region. Rather, this analysis is based on a static model that indicates the importance of component cost and benefits and the relative attractiveness of DG under different conditions.

\subsection{Fuel Cost Sensitivity}

The pie chart shown in Figure 16 provides a breakout of DG Costs for a $200 \mathrm{~kW}$ Turbine using natural gas at an $80 \%$ capacity factor. Key variables include fuel price, DG system efficiency, and electric standby rates.

Figure 16. Annual cost components for $200 \mathrm{~kW}$ DG with $80 \%$ capacity factor at projected Annual Energy Outlook prices for commercial natural gas

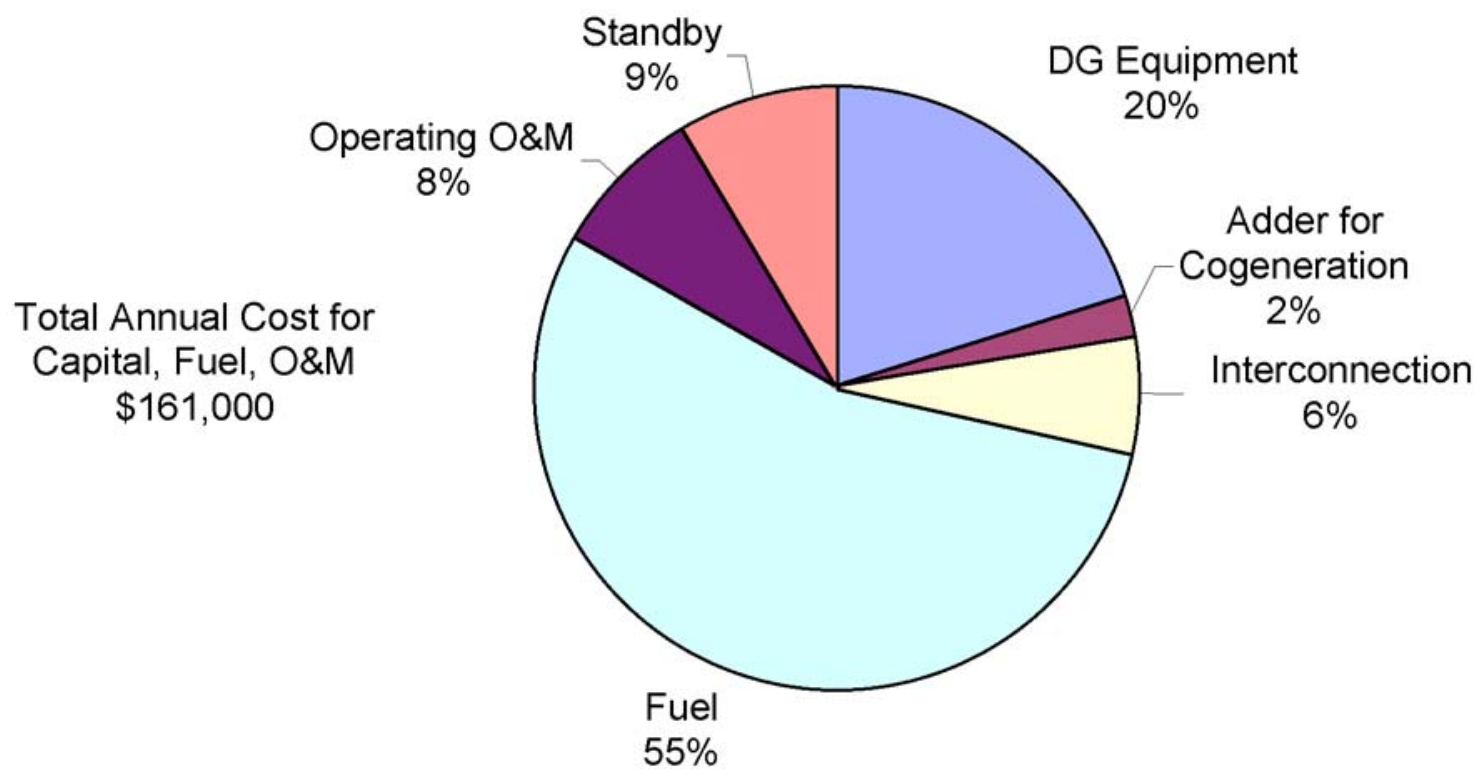

The effects of varying the fuel price and adding cogeneration are shown in Figure 17. Gas and electricity prices for New Jersey and Pennsylvania are also indicated on this figure. The natural 
gas prices in Figure 17 for New Jersey and Pennsylvania are 1993 thru 2001 state averages while electric prices are state averages for 2002. The spark-spread is the difference between the cost of generating power and the cost of purchasing power. In both New Jersey and Pennsylvania, the spark spread is negative (i.e., it's cheaper to buy than to generate) unless cogeneration is used.

Table 25 indicates the variability of natural gas prices over time and within the PJM service area since 1993. Because fuel is the predominant cost for DG, wide variations in natural gas prices make the DG system's economic feasibility uncertain. For instance, in 1998 the commercial price of natural gas in New Jersey was $\$ 3.70$ per mmBtu, less than half the price in Pennsylvania. From 1993 through 2000, natural gas prices averaged $\$ 1.50 / \mathrm{mmBtu}$ less in New Jersey than in Pennsylvania and \$0.94/mmBtu less than Maryland, a difference of $24 \%$ and $16 \%$ respectively (Table 25). In addition to lower gas prices, commercial electricity prices are somewhat higher in New Jersey than Pennsylvania. This combination leads to the more attractive spark spread for a cogeneration microturbine in New Jersey shown in Figure 17, compared to that of Pennsylvania.

Figure 17. DG electricity cost as function of gas price for microturbine

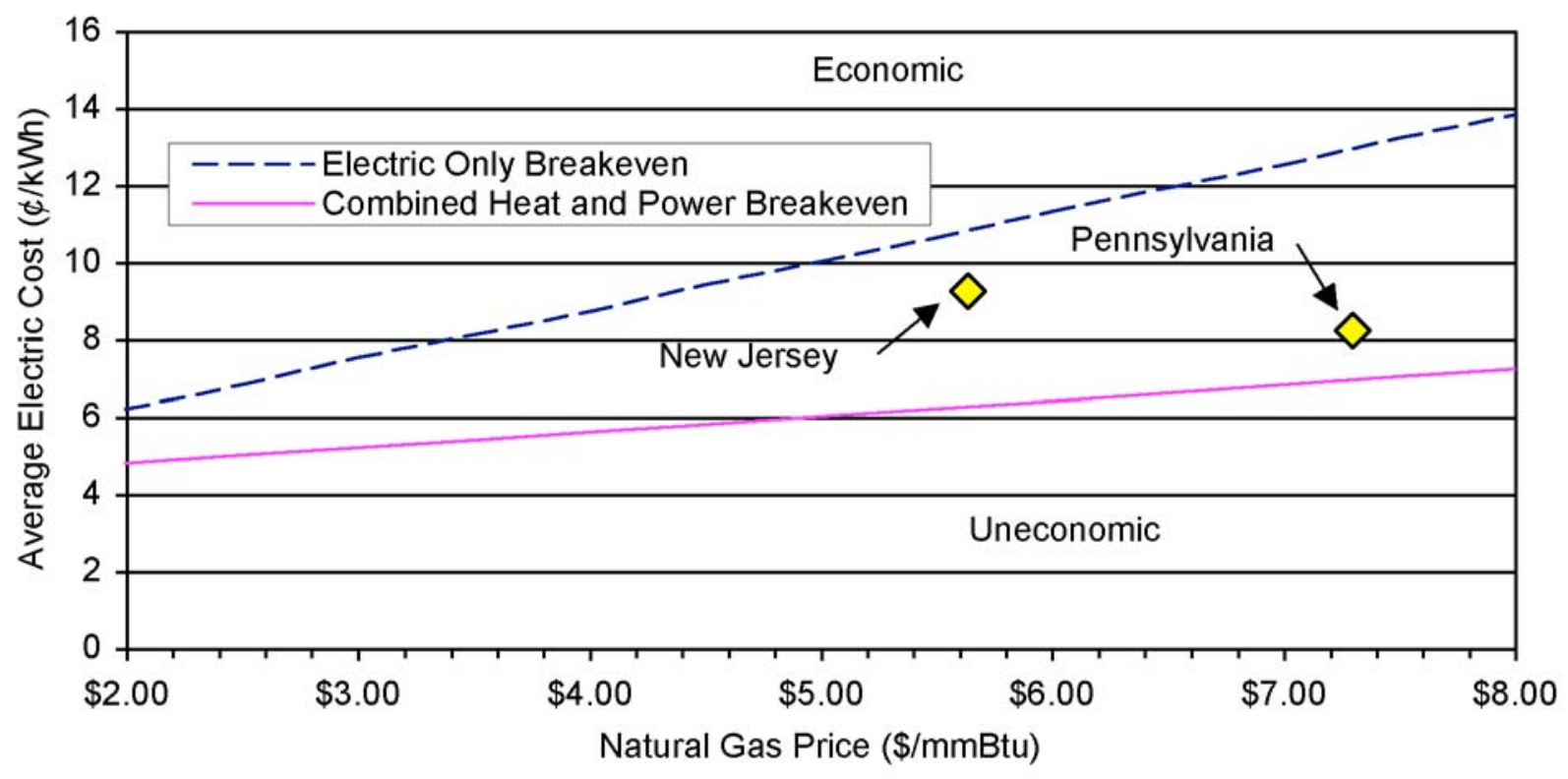


Table 25. Commercial and industrial prices of natural gas in PJM service area for 1993 through 2001

\begin{tabular}{|c|c|c|c|c|c|c|}
\hline & \multirow[b]{2}{*}{ Maryland } & \multirow[b]{2}{*}{ New Jersey } & \multirow[b]{2}{*}{ Penn. } & \multirow[b]{2}{*}{ U.S. Avg. } & \multicolumn{2}{|c|}{$\begin{array}{c}\text { Range of } 3 \text { States to U.S. } \\
\text { Average }\end{array}$} \\
\hline & & & & & Low & High \\
\hline \multicolumn{7}{|c|}{ Commercial } \\
\hline 1993 & 5.72 & 5.6 & 5.99 & 5.22 & 1.07 & 1.15 \\
\hline 1994 & 5.46 & 6.03 & 6.5 & 5.44 & 1.00 & 1.19 \\
\hline 1995 & 5.06 & 5.76 & 6.28 & 5.05 & 1.00 & 1.24 \\
\hline 1996 & 6.08 & 6.14 & 6.44 & 5.4 & 1.13 & 1.19 \\
\hline 1997 & 6.53 & 5.88 & 7.35 & 5.8 & 1.01 & 1.27 \\
\hline 1998 & 6.65 & 3.7 & 7.43 & 5.48 & 0.68 & 1.36 \\
\hline 1999 & 6.95 & 3.99 & 7.29 & 5.33 & 0.75 & 1.37 \\
\hline 2000 & 8.08 & 5.92 & 7.72 & 6.59 & 0.90 & 1.23 \\
\hline 2001 & NA & 7.73 & 10.68 & & & \\
\hline Avg. & & & & & 0.94 & 1.25 \\
\hline \multicolumn{7}{|c|}{ Industrial } \\
\hline 1993 & 3.59 & 3.7 & 3.85 & 3.07 & 1.17 & 1.25 \\
\hline 1994 & 4.04 & 3.64 & 4.01 & 3.05 & 1.19 & 1.32 \\
\hline 1995 & 3.21 & 3.11 & 3.9 & 2.71 & 1.15 & 1.44 \\
\hline 1996 & 5.36 & 3.82 & 4.12 & 3.42 & 1.12 & 1.57 \\
\hline 1997 & 3.25 & 3.78 & 4.61 & 3.59 & 0.91 & 1.28 \\
\hline 1998 & 5.26 & 2.97 & 4.15 & 3.14 & 0.95 & 1.68 \\
\hline 1999 & 5.69 & 3.14 & 3.99 & 3.10 & 1.01 & 1.84 \\
\hline 2000 & 7.86 & 5.15 & 5.03 & 4.48 & 1.12 & 1.75 \\
\hline 2001 & NA & 5.4 & 7.47 & & & \\
\hline Avg. & & & & & 1.08 & 1.52 \\
\hline
\end{tabular}

\subsection{Standby Cost Sensitivity}

Standby costs must also be considered in determining the economics of DG. These costs are part of the distribution utility's rate structure. They can vary significantly by utility service area and can make a significant difference in DG's attractiveness. For instance, Figure 16 indicates that standby costs are typically $9 \%$ of total annual costs. However, standby rates for two service areas within PJM range from $0.5 \varnothing / \mathrm{kWh}(\mathrm{PSE} \& \mathrm{G})$ to $1.4 \mathrm{c} / \mathrm{kWh}(\mathrm{PP} \& \mathrm{~L})$. The standby rate in the PP\&L service area would increase the total annual costs by about $10 \%$ as compared to the PSE\&G rate. In Figure 17, incorporating the PP\&L standby costs would shift Pennsylvania electric prices (benefits) down by $0.9 \notin / \mathrm{kWh}$. This would make DG unattractive in Pennsylvania even with the added energy efficiency benefits of CHP. Using the PSE\&G standby rates for DG would have much less effect on New Jersey prices $(0.5 \notin / \mathrm{kWh})$.

\subsection{Results for a CHP Case in the PJM Region}

Table 26 presents three different fuel price/avoided cost rate scenarios for commercial and industrial DG owners. Commercial natural gas prices and electric rates are applied to the turbine technology up to $1,000 \mathrm{~kW}$ and industrial gas prices for turbines $1 \mathrm{MW}$ and larger. The scenarios are: AEO Mid Atlantic with the average price of natural gas and electricity for commercial and industrial sectors projected by EIA for 2003 through 2020 in 2000 dollars; New Jersey is the 
average electric price in 2000 for electricity and the state-average price of commercial and industrial natural gas for 1993 through 2001; Pennsylvania is from the same sources as New Jersey. Standby electric costs are: $1.0 \phi / \mathrm{kWh}$ for AEO Mid Atlantic, $0.5 \phi / \mathrm{kWh}$ for New Jersey, and $1.4 \notin / \mathrm{kWh}$ for Pennsylvania. The New Jersey standby rates are based on PSE\&G and the Pennsylvania standby rates are based on PP\&L. The difference in standby rates between PSE\&G and PPL are quite large. This is reflected in Table 26 (along with differences in the spark spread) where the simple payback for DG in Pennsylvania is much longer than in New Jersey or AEO Mid Atlantic. If a DG project has negative net benefits, such as some in Pennsylvania, the payback equation is also negative and the project never recovers its costs.

Table 26. Net benefits for alternative DG technologies and fuel price scenarios

\begin{tabular}{|c|c|c|c|}
\hline $\begin{array}{c}\text { DG Turbine size } \\
\text { kw }\end{array}$ & $\begin{array}{l}\text { Installed } \\
\text { Cost } / \mathrm{kW}\end{array}$ & $\begin{array}{c}\text { Avoided Elec \& NG } \\
\text { Net Benefit/kWh }\end{array}$ & $\begin{array}{c}\text { Simple Payback } \\
\text { (years) }\end{array}$ \\
\hline \multicolumn{4}{|c|}{ Recent New Jersey Prices and 0.5ф/kWh Standby Charge } \\
\hline $45-75$ & $\$ 1,383$ & $\$ 0.025$ & 7.8 \\
\hline $75-150$ & $\$ 1,231$ & $\$ 0.028$ & 6.2 \\
\hline $150-300$ & $\$ 1,074$ & $\$ 0.033$ & 4.7 \\
\hline $300-600$ & $\$ 1,015$ & $\$ 0.034$ & 4.3 \\
\hline $600-1000$ & $\$ 757$ & $\$ 0.042$ & 2.6 \\
\hline $1000-2500$ & $\$ 704$ & $\$ 0.040$ & 2.5 \\
\hline $2500-5000$ & $\$ 592$ & $\$ 0.044$ & 1.9 \\
\hline $5000-10000$ & $\$ 550$ & $\$ 0.045$ & 1.7 \\
\hline $10000-20000$ & $\$ 488$ & $\$ 0.047$ & 1.5 \\
\hline \multicolumn{4}{|c|}{ AEO Mid Atlantic Projected Prices and $1.0 \phi / \mathrm{kWh}$ Standby Charge } \\
\hline $45-75$ & $\$ 1,383$ & $\$ 0.011$ & 17.9 \\
\hline $75-150$ & $\$ 1,231$ & $\$ 0.014$ & 12.4 \\
\hline $150-300$ & $\$ 1,074$ & $\$ 0.018$ & 8.4 \\
\hline $300-600$ & $\$ 1,015$ & $\$ 0.019$ & 7.4 \\
\hline $600-1000$ & $\$ 757$ & $\$ 0.027$ & 3.9 \\
\hline $1000-2500$ & $\$ 704$ & $\$ 0.006$ & 18.2 \\
\hline $2500-5000$ & $\$ 592$ & $\$ 0.009$ & 9.5 \\
\hline $5000-10000$ & $\$ 550$ & $\$ 0.010$ & 7.5 \\
\hline $10000-20000$ & $\$ 488$ & $\$ 0.012$ & 5.9 \\
\hline \multicolumn{4}{|c|}{ Recent Pennsylvania Prices and $1.4 \phi / k W h$ Standby Charge } \\
\hline $45-75$ & $\$ 1,383$ & $(\$ 0.000)$ & $(1,518.5)$ \\
\hline $75-150$ & $\$ 1,231$ & $\$ 0.003$ & 59.4 \\
\hline $150-300$ & $\$ 1,074$ & $\$ 0.007$ & 21.4 \\
\hline $300-600$ & $\$ 1,015$ & $\$ 0.008$ & 17.4 \\
\hline $600-1000$ & $\$ 757$ & $\$ 0.016$ & 6.7 \\
\hline $1000-2500$ & $\$ 704$ & $\$ 0.000$ & 550.2 \\
\hline $2500-5000$ & $\$ 592$ & $\$ 0.004$ & 23.6 \\
\hline $5000-10000$ & $\$ 550$ & $\$ 0.005$ & 15.2 \\
\hline $10000-20000$ & $\$ 488$ & $\$ 0.007$ & 10.6 \\
\hline
\end{tabular}

Source and assumptions: For installed costs and fuel efficiency: RDC 2001, Building Cooling, Heating, and Power (BCHP): A Market Assessment. Other assumptions include capacity factor of 0.8, DG heat efficiency of 0.75 , displaced boiler heat efficiency of 0.8 , installed cost adder for cogeneration $\$ 150$ per $\mathrm{kW}$, and interconnection cost of $\$ 50$ per $\mathrm{kW}$. (Commercial prices apply to turbines up to $1,000 \mathrm{~kW}$, industrial prices for $1,000 \mathrm{kWh}$ and greater) 
In summary, the benefits and costs to the DG owner within PJM are highly variable depending on the owner's location and utility service area. Under electric and gas prices projected for the Mid Atlantic region, DG that provides Combined Heat and Power could be potentially attractive for DG turbines above $100 \mathrm{~kW}$. However, this assumes standby power rates of $1.0 \notin / \mathrm{kWh}$ or less. 


\section{Conclusions}

Several tools have been used in this study to examine the market value of DER benefits. Financial benefits to the owner from reduced utility purchases and cogeneration are most easily calculated, but other factors can play a role. The DER system may also be able to provide ancillary services to the grid or reduce regional emissions. If the system owner is allowed to sell these services at their market value, it will increase the owner's revenue and profitability. For the cases examined here, the addition of ancillary services (in the form of reserves) or emissions credits reduced the payback period by roughly one year, for those projects that were economically viable. The operating mode of the DG (either baseload or peaking hours only) can also influence the DER system's profitability, both because of the difference in electricity prices for those two periods and the amount of thermal energy recovered.

In our example, the DER is profitable to the owner using the PSE\&G rates, with paybacks less than five years for most DER sizes and technologies. This is especially true if the equipment is used for CHP and if the owner can sell its capacity into the reserves market when it is not otherwise operating. This can provide an additional $\$ 16 / \mathrm{kW} / \mathrm{yr}$ if the DG operates only during peak periods (8am-8pm weekdays).

It is more difficult to assess the value of DER to the utility (unless they are the DG owner as well). While it will not have to purchase as much electricity, it will also receive lower revenue from the DG owner. The amount of the difference depends strongly on its rate structure, including energy, standby, and demand charges during the peak and off-peak periods. For the two utilities examined here, net annual revenue would decline from 40 to $370 \$ / \mathrm{kW}$ of installed DER capacity. The utility revenue decline is greatest for base-loaded DER units. There is a more location-specific savings that the utility will gain through the deployment of DER on their system: the deferral of distribution and transmission additions and consequent cost increases. We calculated a representative set of values for the utilities in the PJM region based on their systemwide marginal costs. The potential savings to the eleven utilities in the PJM region was calculated to be about $\$ 150 / \mathrm{kW}$ of DG capacity. In many areas of their territory, where capacity is constrained and difficult to expand, the savings could be much higher.

The utility may also see benefits by having an additional supplier of ancillary services. We calculated the amount of funds the owner could receive by selling into the reserves market. This supply helps the utility in purchasing needed reserves when the DG capacity is not itself running. Multiple DG projects can also provide additional reliability as compared to the same capacity in a single central station. However, most systems today are large enough that typically sized central plants do not have a significant impact on regional reliability. Instead, contingency reserves are set by the largest plant or transmission line and capacity requirements are set by a percentage of overall demand.

One of the principal societal benefits of DG is improved air quality. To the extent that cogeneration is used to improve the overall system energy efficiency, and to the extent that cleaner fuels are substituted for more-polluting fuels, DG will reduce the net regional emissions. Our analysis showed that DER in the PJM region, especially as CHP, could reduce $\mathrm{NO}_{\mathrm{X}}$ emissions by as much as $7.3 \mathrm{lb} / \mathrm{MWh}, \mathrm{SO}_{2}$ by as much as $13 \mathrm{lb} / \mathrm{MWh}$, and $\mathrm{CO}_{2}$ by almost 2000 lb/MWh. Assuming market values for the $\mathrm{SO}_{2}$ and $\mathrm{NO}_{\mathrm{X}}$ of $\$ 200 /$ ton and $\$ 1500 /$ ton (with $\mathrm{NO}_{\mathrm{X}}$ 
charges only during the summer months) the savings can be as much as $0.31 \varnothing / \mathrm{kWh}$. Who reaps these benefits depends on the regulations involved in calculation and sale of emission permits (as well as the location of the DER and the displaced central generators), but in the end all of society has the benefit of cleaner air.

In section 1 we presented a table of potential benefits from DG that we would attempt to quantify. In Table 27, we list the results for each area identified.

Table 27. Results from quantification of benefits.

\begin{tabular}{|c|c|c|c|}
\hline Benefit & Owner & Utility & Society \\
\hline Lower Cost & $\begin{array}{l}\text { Economics are favorable } \\
\text { for CHP systems for } \\
\text { some, but not all, utility } \\
\text { rate structures, see Table } \\
17 \text { and Table } 26\end{array}$ & $\begin{array}{l}\text { Based on net energy } \\
\text { sales, distribution utilities } \\
\text { may lose between } 0.5 \text { and } \\
4.5 \phi / \mathrm{kWh} \text {, see Table } 20\end{array}$ & $\begin{array}{l}\text { CHP systems produce } \\
\text { electricity at an } \\
\text { economically attractive } \\
\text { variable cost (from } 2.6 \text { to } \\
3.2 \phi / k W h \text { ), thus } \\
\text { contributing to a more } \\
\text { competitive market, see } \\
\text { Figure A-4 }\end{array}$ \\
\hline Reliability & $\begin{array}{l}\text { Electricity service } \\
\text { reliability is a function of } \\
\text { both individual supply unit } \\
\text { reliability and the number } \\
\text { of units, } 100 \% \text { standby } \\
\text { charges seldom justified, } \\
\text { see section } 3.2\end{array}$ & $\begin{array}{l}\text { DG has a small impact on } \\
\text { LOLP compared to larger } \\
\text { central plants, see Table } \\
\mathbf{1 8}\end{array}$ & $\begin{array}{l}\text { Improved power } \\
\text { services, or reduced } \\
\text { economic cost of current } \\
\text { services, see section } \\
2.4 .3\end{array}$ \\
\hline Ancillary services & $\begin{array}{l}\text { Selling reserves could } \\
\text { bring in } \$ 16 \text { to } \$ 26 / \mathrm{kW} / \mathrm{yr} \text {. } \\
\text { See section } 2.4 .4\end{array}$ & $\begin{array}{l}\text { DG may be lower cost } \\
\text { source of ancillary } \\
\text { services. Localized } \\
\text { voltage support expected } \\
\text { to be valuable - not yet } \\
\text { evaluated }\end{array}$ & \\
\hline $\begin{array}{l}\text { Emissions } \\
\text { reductions }\end{array}$ & $\begin{array}{l}\text { Emissions credits valued } \\
\text { at } 0.24 \phi / \mathrm{kWh} \text {, beneficiary } \\
\text { determined by regulators, } \\
\text { See section } 2.4 .2\end{array}$ & $\begin{array}{l}\text { Emissions credits valued } \\
\text { at } 0.24 \phi / \mathrm{kWh} \text {, beneficiary } \\
\text { determined by regulators, } \\
\text { See section } 2.4 .2\end{array}$ & $\begin{array}{l}\text { In PJM region, CHP } \\
\text { systems save from } 3 \text { to } 7 \\
\text { Ib NO } \mathrm{NO}_{\mathrm{x}} / \mathrm{MWh} \text {, for other } \\
\text { emissions changes, see } \\
\text { Section } 2.4 .2 \text {, especially } \\
\text { Table } 14 \text { and Table } 16 .\end{array}$ \\
\hline $\begin{array}{l}\text { T\&D expansion } \\
\text { postponement }\end{array}$ & & $\begin{array}{l}\text { Savings based on } \\
\text { marginal cost of } \\
\text { expansion versus } \\
\text { embedded cost, see } \\
\text { section } 3.4\end{array}$ & $\begin{array}{l}\text { Delays disruptions and } \\
\text { cost of added T\&D } \\
\text { infrastructure }\end{array}$ \\
\hline
\end{tabular}

From our analysis, successful DER depends most directly upon:

- Utility rates, especially stand-by rates and

- Use of exhaust heat in CHP

Market rule changes that would enable full realization of DER benefits include:

- Use of diversified reliability values in setting stand-by rates,

- Access to emissions savings market for DER owners, and

- Access to ancillary services market for DER owners. 


\section{References}

Bryson, T., W. Major, and K. Darrow, 2001 Assessment of On-Site Power Opportunities in the Industrial Sector, ORNL/TM-2001/169, prepared by Onsite Energy Corporation for Oak Ridge National Laboratory, Oak Ridge, TN, September.

Cowart, Richard H. et al., 2001, Efficient Reliability: The Critical Role of Demand-Side Resources in Power Systems and Markets, prepared for The National Association of Regulatory Utility Commissioners, June.

EIA 2001, Annual Energy Outlook 2002 with Projections to 2020, DOE/EIA-0383(2002), U.S. Department of Energy, Washington, D.C. December.

$<$ http://www.eia.doe.gov/oiaf/aeo/index.html $>$

$<$ ftp://eia.doe.gov/oiaf/aeo/aeo2002.exe>

EPA (Environmental Protection Agency) 2001, E-GRID 2000PC, Version 2.0, Office of Atmospheric Programs, September. <http://www.epa.gov/airmarkets/egrid/>

Farrell, Alex 2002 "NOx Emissions Trading in the Northeast: Trends and Outlook", 2002 Conference on Selective Catalytic Reduction (SCR) and Selective Non-Catalytic Reduction (SNCR) for NOx Control, National Energy Technology Laboratory, May.

$<\underline{\text { http://www.netl.doe.gov/publications/proceedings/02/scr-sncr/Farrell.pdf }>}$

Goel, L. 1998, "Power System Reliability Cost/Benefit Assessment and Application in Perspective," in Computers \& Electrical Engineering, 24, pp. 315-324 .

Hadley, S. and E. Hirst 1998, ORCED: A Model to Simulate the Operations and Costs of BulkPower Markets, ORNL/CON-464, Oak Ridge National Laboratory, Oak Ridge, TN, June. $<$ http://www.ornl.gov/orced/index.html $>$

Hirst, E. and B. Kirby 1997, Ancillary-Service Details: Operating Reserves, ORNL/CON-452, Oak Ridge National Laboratory, Oak Ridge, TN, November.

Hoff, Thomas E., Howard J. Wenger, and Brian K. Farmer, "Distributed Generation: An Alternative to Electric Utility Investments in System Capacity", by Thomas E. Hoff, Energy Policy 24(2): 137-147 (September 96) <http://www.clean-power.com/research.asp>

Iannucci, Joe, Susan Horgan, James Eyer, Lloyd Cibulka, 2002, Analysis of $\mathrm{NO}_{\mathrm{X}}$ Emissions Limits for Distributed Generation in Texas, Distributed Utility Associates, Livermore, CA, May.

Kirby, B. 2001, "Restructured Electricity Markets Offer Increased Complexities and Opportunities for Cogeneration," Cogeneration and Competitive Power Journal .

Kirby, B. and E. Hirst 2000, Customer-Specific Metrics for the Regulation and Load-Following Ancillary Services, ORNL/CON-474, Oak Ridge National Laboratory, Oak Ridge, TN, January.

Platts 2002, Powerdat Database, Platts, Inc., Boulder, Colo. 
Poore, W. P., T. K. Stovall, B. J. Kirby, D. T. Rizy, J. D. Kueck, J. P. Stovall, 2002, Connecting Distributed Energy Resources to the Grid: Their Benefits to the DER Owner/Customer, the Utility, and Society, ORNL/TM-2001/290, Oak Ridge National Laboratory, Oak Ridge, TN March

RDC (Resource Dynamics Corporation) 2001, Building Cooling, Heating, and Power (BCHP): A Market Assessment, Draft, September.

Smith, Douglas J., 2000 "Cogeneration, Distributed Generation and Peak Shaving Drive the Market for Small Gas Turbines," in Power Engineering, 104(10), pp. $70-74$ (October 2000).

Smith, Douglas J. 2001, "Distributed Generation: The Power to Choose," in Power Engineering, 105(3), pp. 32-36 (March).

U.S. Department of Energy, Strategic Plan for Distributed Energy Resources, prepared by the Office of Energy Efficiency and Renewable Energy and Office of Fissil Energy, September 2000 .

United States Combined Heat \& Power Association 2001, National CHP Roadmap-Doubling Combined Heat and Power Capacity in the United States by 2010, prepared by the United States Combined Heat \& Power Association in cooperation with U.S. Department of Energy, U.S. Environmental Protection Agency, March. 


\section{Appendix A - ORCED Methodology}

The ORCED model uses the collection of available electricity supply sources to dispatch plants to meet the defined demands for a single year of operation. The ORCED version used for this study models a single region without internal transmission constraints. It can handle up to 200 power plants and models two seasons, peak and off-peak. Four customer categories were used for the analysis: residential, commercial, industrial, and other.

The model was developed at Oak Ridge National Laboratory to examine numerous facets of a restructured electricity market (Hadley and Hirst 1998). ORCED is focused on power generation for a region, but it also calculates a number of key financial and operating parameters. The ORCED model has been used in a variety of studies by different groups across the country including:

- Impact of restructuring on power prices in the Pacific Northwest

- $\quad$ Potential for economic biomass cofiring on a state and regional basis

- National carbon emissions under differing energy and carbon reducing scenarios

- Impacts of hydropower relicensing on carbon emissions

- Impacts of restructuring on prices and transmission in Oklahoma

- Market incentives for adequate generation capacity in a restructured electricity market

- Stranded cost recovery processes in the mid-Atlantic region

- $\quad$ Effect of NOx emission control implementation plans on system reliability

- $\quad$ Effect of carbon taxes on power production in the Midwest

- Benefits of multiple emission controls strategies

- Impacts of restructuring on prices and transmission in Oklahoma

The model takes the inputs on supply and demand described above and dispatches plants to meet the defined demands for a single year of operation. Several versions of the model have been developed over the years depending on the needs of the study.

\section{A.1 Plant Aggregation}

The 775 units in PJM from the EIA database were aggregated into 200 "bins" for use within ORCED (Table A-1). First, the units were grouped on a broad level into 24 types based on their technology, fuel-type, and dispatchability. Plants that were labeled as "must-run" in the EIA database are treated separately in ORCED from dispatchable plants of the same type. 
Table A-1. PJM units aggregated by technology, fuel, and dispatchability

\begin{tabular}{|c|c|c|c|}
\hline Plant Type & $\begin{array}{c}\text { Capacity } \\
\text { MW }\end{array}$ & $\begin{array}{l}\text { Number } \\
\text { of Units }\end{array}$ & $\begin{array}{l}\text { Number after } \\
\text { Aggregation }\end{array}$ \\
\hline Non-grid units & 1271 & 115 & 0 \\
\hline Hydro & 1177 & 48 & 1 \\
\hline Pumped Storage & 1715 & 16 & 1 \\
\hline Oil ST Low S & 7912 & 36 & 28 \\
\hline Oil ST High S & 137 & 1 & 1 \\
\hline Oil CT Distillate & 3744 & 177 & 32 \\
\hline Gas ST & 339 & 5 & 1 \\
\hline Gas CT & 4079 & 76 & 28 \\
\hline Gas CC & 1660 & 12 & 12 \\
\hline Nuclear & 12977 & 28 & 13 \\
\hline Coal Low S & 5225 & 21 & 17 \\
\hline Coal Medium S & 2238 & 11 & 11 \\
\hline Coal High S & 8580 & 30 & 22 \\
\hline Coal Scrubbed S & 2876 & 8 & 8 \\
\hline M_Hydro & 41 & 14 & 1 \\
\hline M_Oil CT_D & 2 & 3 & 1 \\
\hline M_Gas ST & 11 & 3 & 1 \\
\hline M_Gas CC & 2959 & 79 & 10 \\
\hline M_MSW & 546 & 66 & 5 \\
\hline M_Bio & 18 & 2 & 1 \\
\hline M_Other Ren & 0 & 1 & 1 \\
\hline M_Coal_M & 217 & 3 & 1 \\
\hline M_Coal_H & 1 & 2 & 1 \\
\hline M_Coal_S & 704 & 18 & 3 \\
\hline Total & $57157^{*}$ & 775 & 200 \\
\hline
\end{tabular}

* Does not include $1271 \mathrm{MW}$ of non-grid units nor 835 MW from units that are mixed grid and non-grid

$M_{-}=$must run plant, cogeneration or non-dispatchable

$S=$ Sulfur content

$\mathrm{ST}=$ steam turbine

$\mathrm{CT}=$ combustion turbine

$\mathrm{CC}=$ combined cycle
Next, each of the 24 groupings was split into a number of bins for use in ORCED. For example, the 76 gas combustion turbines (CT) were aggregated to create $28 \mathrm{CT}$ bins within ORCED. The 76 units were sorted in order of increasing variable cost. The three lowest cost units were consolidated into the first bin, then the next six units were consolidated into the second, and so on until all units were in one of the specified bins. Variable cost was used to sort plants into bins because variable cost is an accurate criterion for dispatching plants. Consolidating plants of greatly differing variable costs could lead to over- or under-dispatching a plant compared to what it should be if dispatched separately.

The EIA database may have separate records for each portion of a single unit owned by separate companies. For example, there are really just 13 nuclear units in the PJM region, but several of these are partially owned by more than one utility, adding up to 28 units in the database. Multiple ownership of single units was accounted for during the binning process.

Hydro and pumped storage units are treated differently in ORCED from other plants. Hydropower is preferentially used

to reduce peak power demands, while still maintaining capacity and energy constraints. Pumped storage plants both reduce peak demands and purchase power during low demand periods.

The capacities and variable costs of the resulting set of plants for use in ORCED are shown in Figure A-1. Most plants are in the 100 to $200 \mathrm{MW}$ range, although some are much higher. The nuclear plants are numbered between 107 and 119 in the figure. Note their low variable cost, since much of their costs are treated separately as fixed cost in the calculations. Key parameters such as fuel cost, other operating costs, capital cost, heat rate, and emissions are calculated using a weighted average of all the units within the aggregated bin for that plant type. 
Figure A-1. Operating cost and capacity of aggregated power plants in PJM region

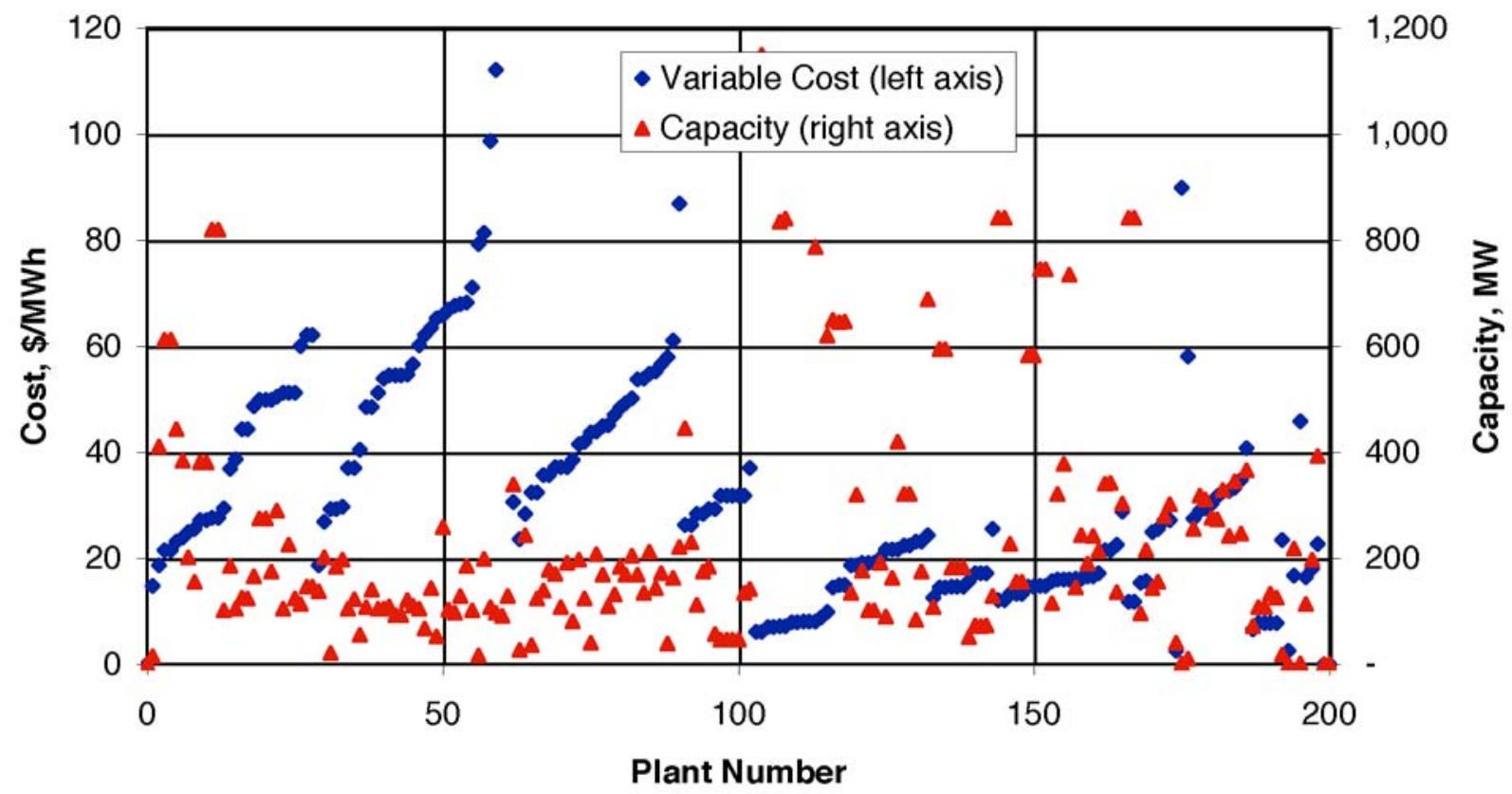

The major groupings (shown by the rising variable costs) represent different technologies or fuels. The actual order of these groupings is simply used for labeling and not the order for dispatching purposes.

\section{A.2 Load Duration Curves}

Hourly loads for PJM are shown in Figure A-2. The power loads from all of the hours of each season are stacked in increasing order to create the LDC for each season (Figure A-3). The curves show the percentage of time that demand was greater than or equal to a given power level. For example, during the peak season, demand was $20,000 \mathrm{MW}$ or greater $100 \%$ of the time. For $50 \%$ of the season, demand was $31,000 \mathrm{MW}$ or greater, and for $10 \%$ of the season, demand was $42,000 \mathrm{MW}$ or greater. The off-peak season has a lower, flatter curve than the peak season because of the lack of air-conditioning loads that drive the peak during the summer months. Combined, the two curves create the annual LDC. ORCED uses a three-segment line to represent each LDC; we fit line segments to match the curves. These are shown in the figure as well. 
Figure A-2. PJM hourly system demand for 1999

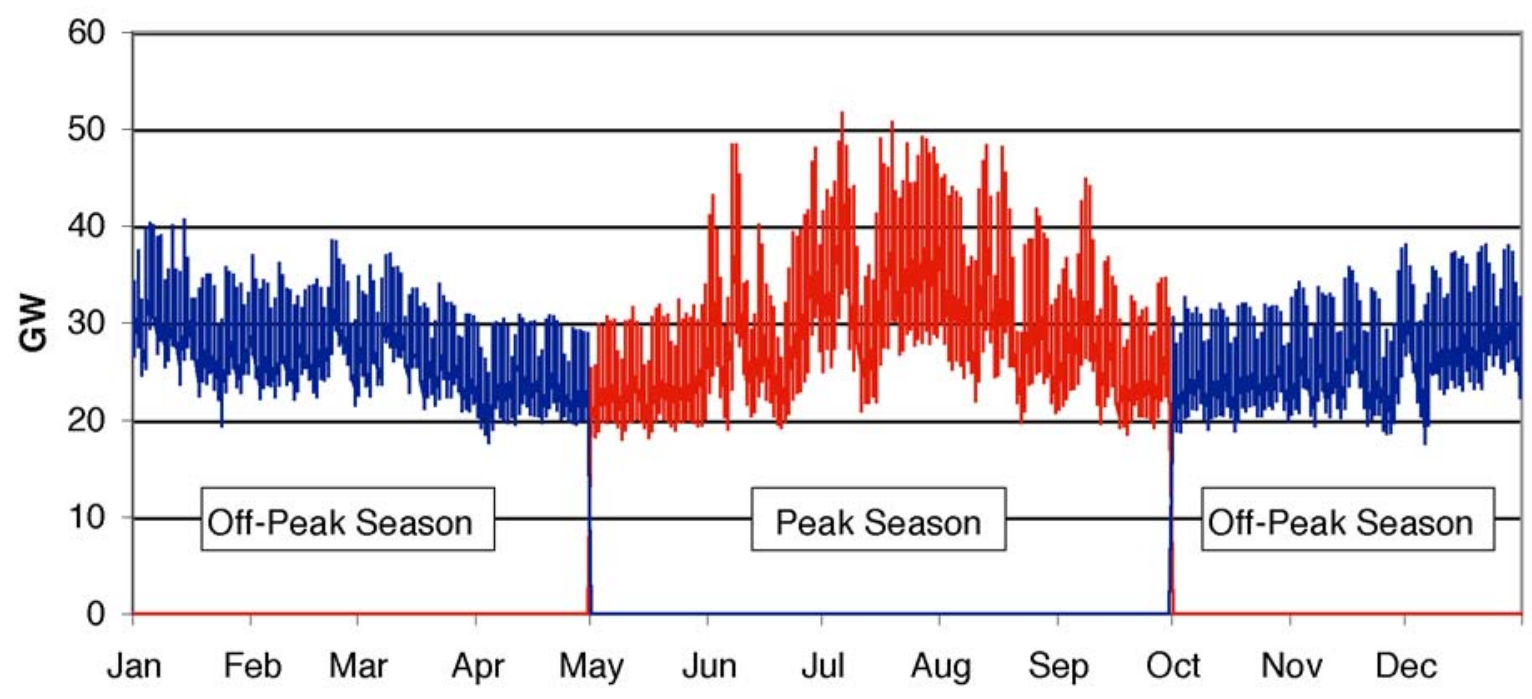

Figure A-3. Load Duration Curves for PJM

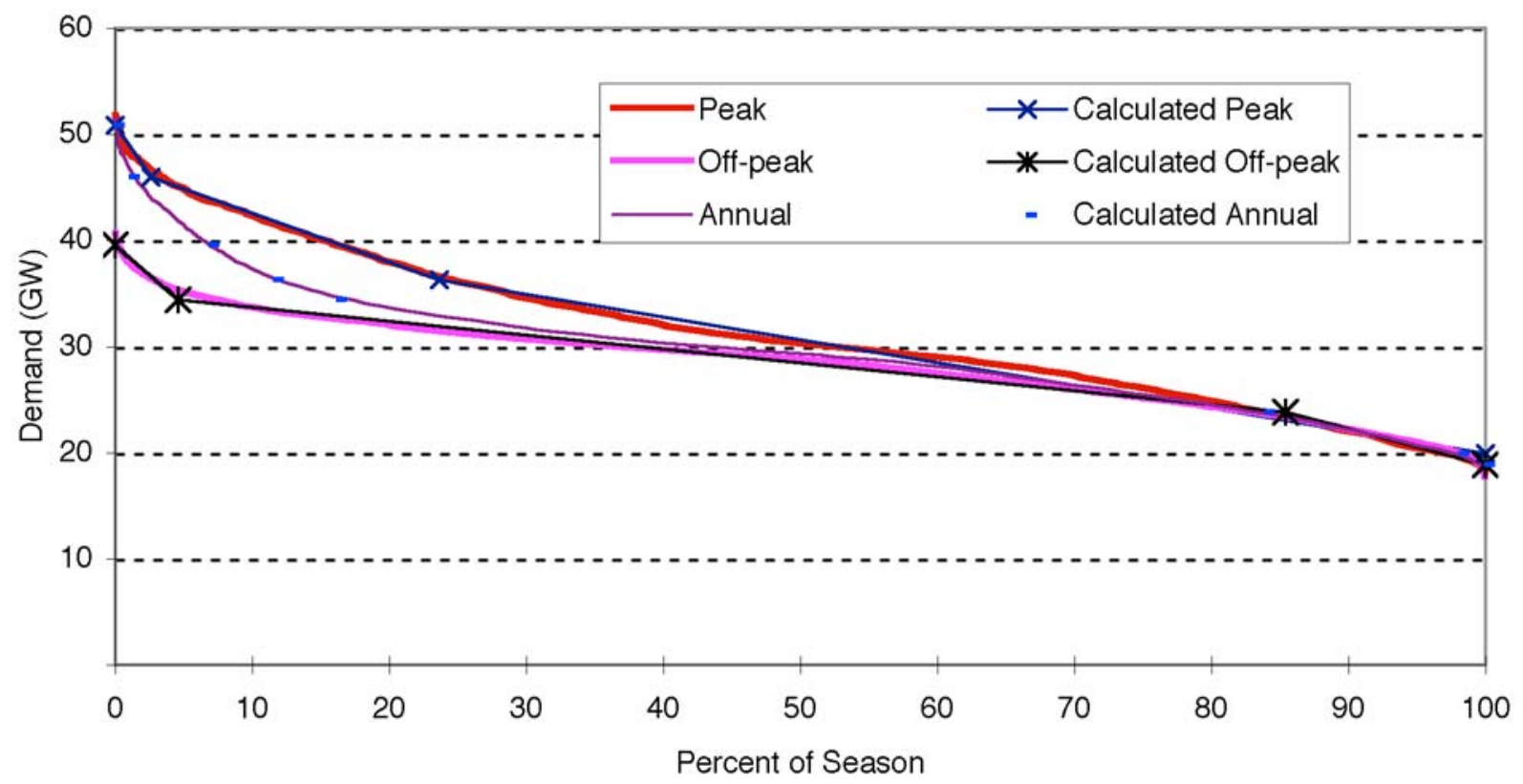

A preliminary analysis of customer class differences is not reported here but may prove useful in future evaluations. Four customer categories are used for the analysis: residential, commercial, industrial, and other. Sales levels for each can be found from EIA data (EIA 2000) and are shown in Table A-2. However, the sum of their sales does not match the total amount of energy when summing the hourly demands from Figure A-2. Two reasons for the difference are that sales amounts do not include the losses during transmission and distribution nor the wholesale sales in and out of the region. 
Tentative load duration curves and losses were established for each customer category. In addition, the "other" category was increased to include wholesale sales to other regions so that total sales matched total generation. Then the load duration curves for the categories were adjusted so that the sum of their curves equaled the curves in Figure A-3. Key values for each category are shown in Table A-2. The Export values shown in the table were combined with the Other Retail sales in the model for our analysis.

Table A-2. 1999 PJM electric sales with calculated factors to match system LDC

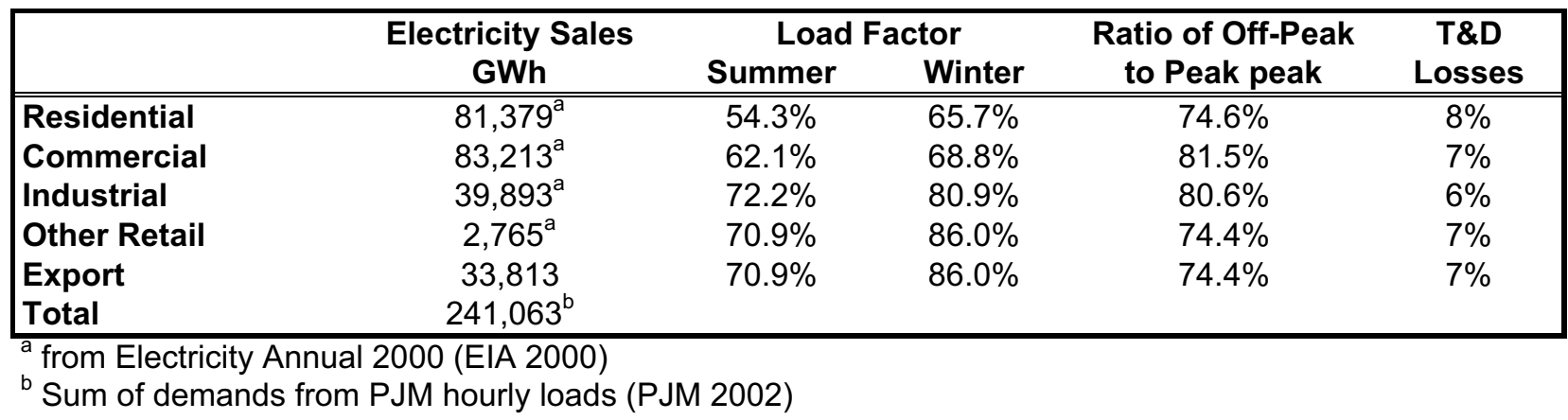

\section{A.3 Power Plant Dispatch Protocol}

Once the supply and demand have been defined, the model calculates the market bid price based on the variable cost for each plant, including fuel, variable operating costs, and emissions permits. It then sorts the plants in order of increasing variable cost. Those plants that are mustrun or are cogenerators (and are therefore outside the control of dispatchers) have their prices set at zero so that they are dispatched first. The area under the LDC for each season is gradually filled by the available plants so that total demands are met by the plants in order of increasing price.

Because plants are not available $100 \%$ of the time, their forced outages must be taken into account and higher-cost plants dispatched to make up their lost production. The model does this in two ways. Most plants have their total capacity derated by the fraction of time they are not available. A $100 \mathrm{MW}$ plant with a 10\% forced outage rate would be treated as a $90 \mathrm{MW}$ plant. The ten largest and least expensive plants have their outages treated probabilistically. All of the calculations for dispatch are done twice for each plant: once with the plant available and once without. The resulting dispatching of the remaining plants is convolved together based on the fraction of time that the plant is available. The model can treat more than ten plants probabilistically (as done in section 2.4.3) but little change is noted in the results and the calculation time expands exponentially with each additional plant.

The ORCED model dispatches power plants in two seasons: peak and off-peak. The two seasons are treated slightly differently within ORCED. In the peak season, no outages are planned and the only outages that happen are random forced outages. In the off-peak season, power plant capacities are derated to represent the portion of time they have planned outages, in addition to having forced outages.

As each plant is added to the stack of plants, the fraction of the period they operate is determined (Figure A-4). Plants that are low enough in cost that they are called on for the whole period are 
called baseload plants. In Figure A-4 this includes the must-run, nuclear, and a portion of the coal plants. Once the plant production level reaches the LDC, the plants begin operating for only a portion of the year. In Figure A-4, each dot on the LDC represents the point where a plant reaches full capacity and the next plant in the dispatch order begins operation. For example, one plant (Montour-2, $745 \mathrm{MW}$ ) begins operation at $84.6 \%$ of the period and is at full capacity $81.0 \%$ of the period. In other words, The Montour- 2 plant is feeding power to the grid $84.6 \%$ of the year, and is running at full capacity $81 \%$ of the year. This means it was on the margin $3.6 \%$ of the peak period.

Figure A-4. Peak season dispatch of plants to meet PJM load in order of increasing variable cost. Percentages represent the fraction of energy provided by each plant type in the block.

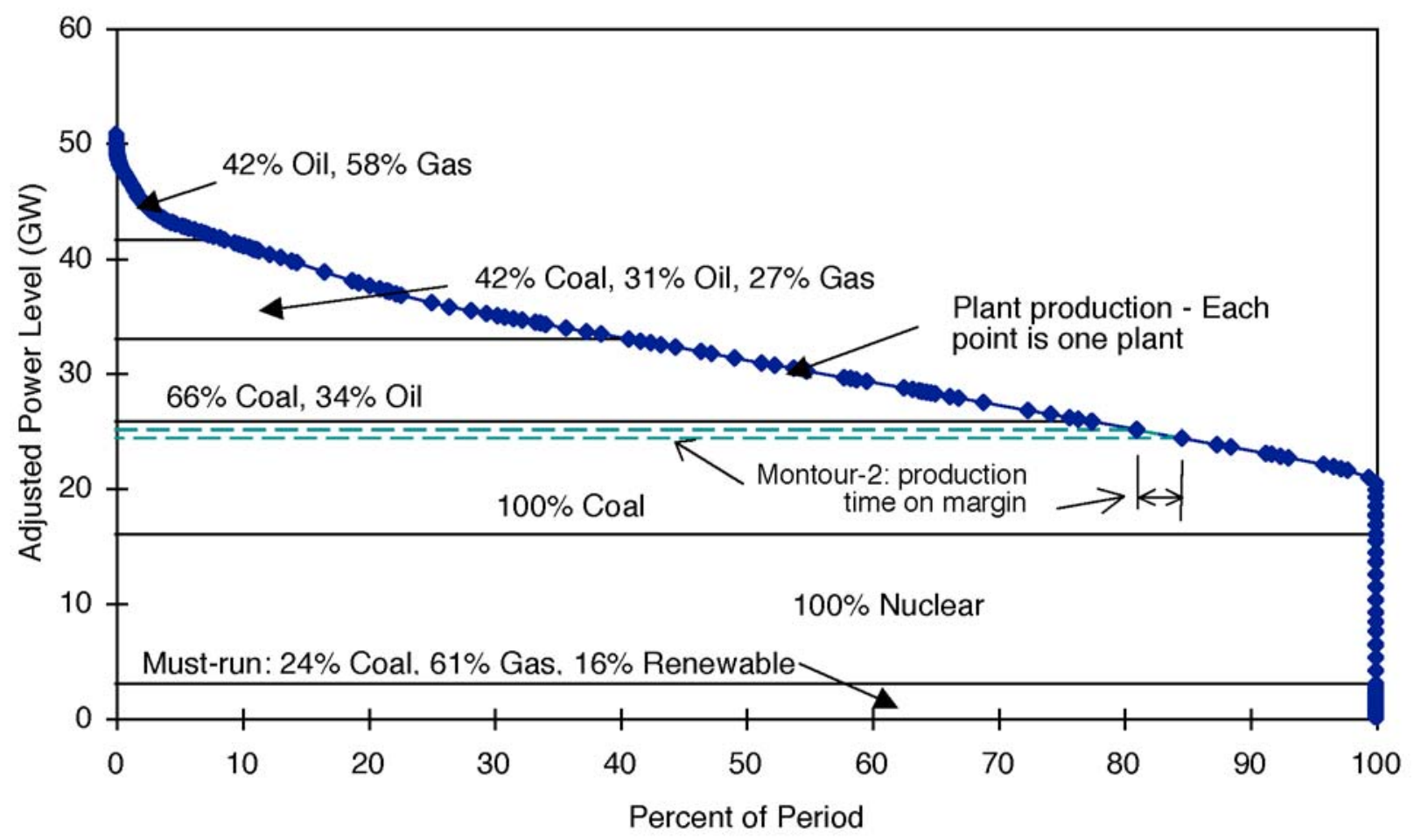

Because plants have different efficiencies, fuel prices, and other variable costs, there can be interleaving of plants with different fuel types. While coal is generally cheaper than oil, some oil plants may have lower costs than some coal plants, and the same occurs with gas and oil plants. The area under the LDC in Figure A-4 has been divided into six major areas with different proportions of plants, but the actual calculations have 200 different slices, one for each plant. The dispatch solution for a given load duration curve can therefore be used to determine the fraction of time each plant type or fuel type is on the margin. Note that some plant types in Figure A-4 are never on the margin, such as Nuclear, because of its low variable cost, and Renewables, because they are not dispatchable. Also note, the fraction of time that a particular fuel type is on the margin is different from the fraction of the system capacity represented by that fuel. For example, because many coal plants are used $100 \%$ of the year, these plants are never on 
the margin, so the fraction of time coal is on the margin will be less than the fraction of coal capacity in the system.

\section{A.4 Dispatch Profile Response to DG}

With the reduction in hourly demands due to the DG, the LDC is lowered. In the Baseload scenario the entire curve is reduced by $100 \mathrm{MW}$. In the Peaking DG scenario, it is more complicated because only some hours are reduced. Since only some hours have demand reduced, the shape of the LDC will change. The LDC is created by sorting each hour's load in order of increasing demand. Reducing only some hours will slightly rearrange the hours so that the net change will reflect the DG's total production.

\section{A.5 Operations, Emissions, and Prices on Hourly Basis}

Once the plants have been dispatched, the marginal plants determined, and energy and ancillary prices set, then revenues to the plants from the different customer categories can be calculated. ORCED also allows calculation of regulated rates for each plant individually based on its embedded costs. With revenues and costs determined, the financial picture for each plant or group of plants can be evaluated for the year. Costs to each customer category can be evaluated as well, which provides an indication of the prices paid for generation. Since plant operations are known, then emissions such as $\mathrm{NO}_{\mathrm{X}}, \mathrm{SO}_{2}$, and carbon dioxide can be found. 